\title{
Dextran Aldehyde in Biocatalysis: More Than a Mere Immobilization System
}

\author{
Veymar G. Tacias-Pascacio ${ }^{1,2}$, Claudia Ortiz ${ }^{3}{ }^{(}$, Nazzoly Rueda $^{3}$, Ángel Berenguer-Murcia ${ }^{4}$, \\ Niuris Acosta ${ }^{5}$ (D) Inmaculada Aranaz ${ }^{5}$, Concepción Civera ${ }^{5}(0)$, Roberto Fernandez-Lafuente ${ }^{6, *(1)}$ \\ and Andrés R. Alcántara $5, * \mathbb{D}$ \\ 1 Tecnológico Nacional de México/Instituto Tecnológico de Tuxtla Gutiérrez, Carretera Panamericana \\ Km. 1080, Tuxtla Gutiérrez 29050, Mexico \\ 2 Facultad de Ciencias de la Nutrición y Alimentos, Universidad de Ciencias y Artes de Chiapas, \\ Tuxtla Gutiérrez 29000, Mexico \\ 3 Escuela de Microbiología, Universidad Industrial de Santander, Bucaramanga 680002, Colombia \\ 4 Departamento de Química Inorgánica e Instituto Universitario de Materiales, Universidad de Alicante, \\ 03080 Alicante, Spain \\ 5 Departamento de Química en Ciencias Farmacéuticas, Facultad de Farmacia, \\ Universidad Complutense de Madrid, 28040 Madrid, Spain \\ 6 Departamento de Biocatálisis, ICP-CSIC, Campus UAM-CSIC, 28049 Madrid, Spain \\ * Correspondence: rfl@icp.csic.es (R.F.-L.); andalcan@ucm.es (A.R.A.); Tel.: +34-91-585-49-41 (R.F.-L.); \\ +34-91-394-18-20 (A.R.A.)
}

Received: 28 June 2019; Accepted: 16 July 2019; Published: 21 July 2019

\begin{abstract}
Dextran aldehyde (dexOx), resulting from the periodate oxidative cleavage of 1,2-diol moiety inside dextran, is a polymer that is very useful in many areas, including as a macromolecular carrier for drug delivery and other biomedical applications. In particular, it has been widely used for chemical engineering of enzymes, with the aim of designing better biocatalysts that possess improved catalytic properties, making them more stable and/or active for different catalytic reactions. This polymer possesses a very flexible hydrophilic structure, which becomes inert after chemical reduction; therefore, dexOx comes to be highly versatile in a biocatalyst design. This paper presents an overview of the multiple applications of dexOx in applied biocatalysis, e.g., to modulate the adsorption of biomolecules on carrier surfaces in affinity chromatography and biosensors design, to serve as a spacer arm between a ligand and the support in biomacromolecule immobilization procedures or to generate artificial microenvironments around the enzyme molecules or to stabilize multimeric enzymes by intersubunit crosslinking, among many other applications.
\end{abstract}

Keywords: dextran; dextran-aldehyde; enzyme immobilization; enzyme modification

\section{Introduction}

Enzymes are undoubtedly the most efficient catalysts ever known, as they can proficiently perform their catalytic function under mild conditions, in a very specific (modifying only the target physiological substrate) and selective (producing only the target product) manner [1-15]. As a result, they are extremely useful in very diverse areas of application. However, the current features of enzyme biocatalysts have been acquired after an extremely long-lasting natural evolution process, thereby improving the physiological function of living organisms. On the other hand, some of these features that are necessary for microorganisms to respond to changes in the environment do not fit the requirements for large-scale industrial applications [16]. Nevertheless, enzymes have found application in many industrial processes, from fine chemistry $[1,12,13]$ to energy production [17-21] or food technology [22-25]. When employed as industrial biocatalysts, the desired enzymatic capability 
may not be always the same; for instance, chemo- and regio-selectivity will be always necessary, while enzyme stereoselectivity would be demanded in the resolution of racemic mixtures or in the desymmetrization of prochiral compounds. Enzyme specificity also makes these biocatalysts very suitable in analytical chemistry [26-29]. Thus, many enzymatic biosensors have been developed to determine the concentration of one specific component inside a very complex mixture (e.g., glucose in blood $[30,31])$. Another application of enzymes can be found in the field of medicine, where they can be supplemented in order to supply some endogenous enzyme deficiencies or to degrade some target deleterious compounds [32,33]. In this case, enzyme specificity and selectivity are both required, as only the target compound must be degraded, without generating any toxic side-product. Conversely, enzyme stability and activity are crucial parameters in most enzyme applications, as enzymes need to remain active during storage, transport, and utilization [34-36]. Stability in a bioreactor involves the resistance of the enzyme to alter its conformation under operation conditions, or against chemical modification if some reactive substrates or by-products are present (e.g., hydrogen peroxide [37]). For biosensors, the operational stability of the enzyme is crucial, since the signal should exist even in the presence of inhibitors, inactivation reagents, etc. [36,38]. In some cases, the lack of any detected signal is the "required signal", as in those cases when the sensor must detect some agents that reduce enzyme activity [39-42]. Thus, it is mandatory to differentiate whether the enzyme has been inactivated by changes in the medium (e.g., drastic $\mathrm{pH}$, or increase temperature) or it is really inhibited by the target compound. On the other hand, if the detection of the compound is performed in situ, e.g., inside a reactor, the enzyme must be resistant to the attack of any other enzyme or metabolite released by the microorganism and changes in the conditions ( $\mathrm{pH}$, for example). Moreover, in biomedicine the enzyme must be stable towards proteolysis and cell capture in other cells different from the target tissue, but it must be able to simultaneously penetrate the target location [38].

Furthermore, enzyme solubility may be a problem in some applications. Clearly, this may not be the case when using enzymes in biomedicine (although there are some circumstances where its immobilization is also required, e.g., in extracorporeal dispositives [43-46]), but in most other applications enzyme immobilization is required, mainly when the enzyme is going to be reused (as happens in industrial biocatalysis). In these cases, it must be separated from the reaction media, or it should be fixed on the tip of a transducer to maximize the signal (e.g., in biosensors) [47-56]. In fact, enzymes, despite being extremely useful in many areas, in many instances need to be improved to optimize their behavior under industrial operational conditions. Fortunately, there are many ways to enhance enzyme capabilities; for instance, the development of metagenomics tools has permitted the exploitation of all biodiversity, including non-cultivable microorganisms or even no longer existing ones [57-60]. On the other hand, directed evolution allows for mimicking natural evolution by specifically improving the target property of the desired enzyme [61-65]. Finally, chemical modification and enzyme immobilization [66-70] are evolving in order to allow the development of more specific and directed enzymatic modifications.

In this sense, dextran aldehyde (hereinafter referred as dexOx) has been used in many cases in the design of improved biocatalysts [70,71]. DexOx is a multifunctional and random coil polymer, commercialized with very different sizes [72], which has been widely used to modify free or immobilized enzymes, to modify supports involved in enzyme manipulation with different objectives, or even as spacer arm in enzyme immobilization. This review will focus on the different uses of this polymer in the design of improved biocatalysts.

\section{Dextran and Dextran Aldehyde (DexOx)}

\subsection{Dextran}

Dextran is a polysaccharide formed by poly- $\alpha$-D-glucosides of microbial origin having glycosidic bonds predominantly C-1 $\rightarrow C-6$, as defined by the IUPAC [73] (Figure 1). This biopolymer, which is naturally synthesized by many bacteria growing on sucrose-containing media [74], presents a great 
variety of lengths (ranging between 3 and $2000 \mathrm{kDa}$ ), and displays between 50 and $97 \%$ of $\alpha-1,6$ linkages, and a small degree of branching $(\alpha-(1 \rightarrow 2), \alpha-(1 \rightarrow 3)$ and/or $\alpha-(1 \rightarrow 4)$ branching points).

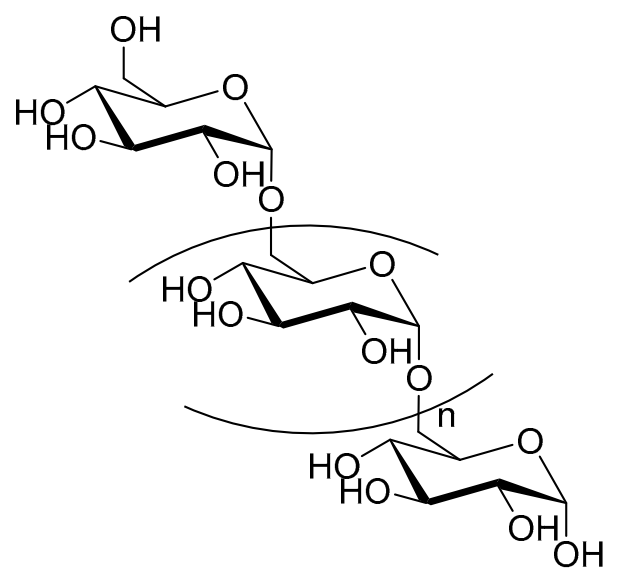

Figure 1. Chemical structure of main component of dextrans $(\alpha-(1 \rightarrow 6)$ linkages).

Dextran is produced by dextransucrases of Leuconostoc spp. [75,76], Weissella spp. [77,78] and lactobacilli $[79,80]$. Currently, most of the commercially available dextrans are obtained from Leuconostoc mesenteroides [81,82]. Traditionally, the main use of low molecular weight fractions of dextrans inside the biotechnology world has been as a plasma volume expander $[83,84]$, not only because of its linear structure and high water solubility, but also because its chemical composition (mainly based on $\alpha-1,6$ linkages). This fact makes dextrans less prone to suffer enzymatic hydrolysis compared to other oligosaccharides based on $\alpha-1,4$ linkages, such as glycogen [85], which may be cleaved by microbial dextranases in the gastrointestinal tract.

The water solubility of dextrans varies depending on the branching degree: on the one hand, those dextrans possessing around $95 \%$ of linear structure are fully soluble. On the other hand, as the branching proportion increases, the solubility progressively decreases, and those dextrans possessing more than $43 \%$ of $\alpha-(1 \rightarrow 3)$ are considered to be water insoluble [86]. In any case, the relatively high water solubility of dextrans, as well as their high stability in both mild acidic and basic conditions and its large amount of hydroxylic groups, make dextrans an excellent material for undertaking different derivatization protocols or any kind of chemical or physical crosslinking $[86,87]$. Generally, the C-2 hydroxyl group is the most reactive, and the conjugation of different molecules to dextran can be carried out following different procedures [86], as depicted in Figure 2. These different methodologies possess a common feature: the glucopyranose ring of the polysaccharide remains unaltered. In any case, the most common form of dextran-modification is probably the generation of aldehyde pendant groups via periodate oxidation, which implies an opening of the heterocyclic ring: this point will be discussed further in Sections 2.2 and 2.3.

Direct esterification (Figure 2a) is generally carried out by conjugation of hydroxyl groups of dextran with carboxylic acid via activation with $N, N$-dicyclohexylcarbodiimide $(\mathrm{Cy}-\mathrm{N}=\mathrm{C}=\mathrm{N}-\mathrm{C} y)$. Many ester prodrugs of dextran, such as most non-steroidal anti-inflammatory (NSAIDs) drugs, have been synthesized through this methodology [88]. Another classical methodology allows the attachment of molecules possessing amine or hydroxyl groups by creating carbamate $\left(\mathbf{b}_{\mathbf{1}}\right)$ or carbonate $\left(\mathbf{b}_{\mathbf{2}}\right)$ ester linkages, following a previous activation of all hydroxyl groups of dextrans using phosgene [89]; some other procedures avoiding the use of toxic phosgene have been also described [90]. Similarly, the activation of dextrans with carbonyldiimidazole and ethylenediamine leads to dextran derivatives possessing pendant amino groups $(\mathbf{c})$, whereby succinimidyl-activated derivatives of other hydroxyl-containing substances can be attached $\left(\mathbf{c}_{1}\right)$. On the other hand, amine containing compounds can be covalently linked to dextran by using the well-known cyanogen bromide activation (d), through 
which an isourea bond is formed $\left(\mathbf{d}_{\mathbf{1}}\right)$. Finally, irreversible etherification of dextrans can be carried out using aliphatic or aromatic halides (e), epoxides (f) or conjugated carboxamides (g).

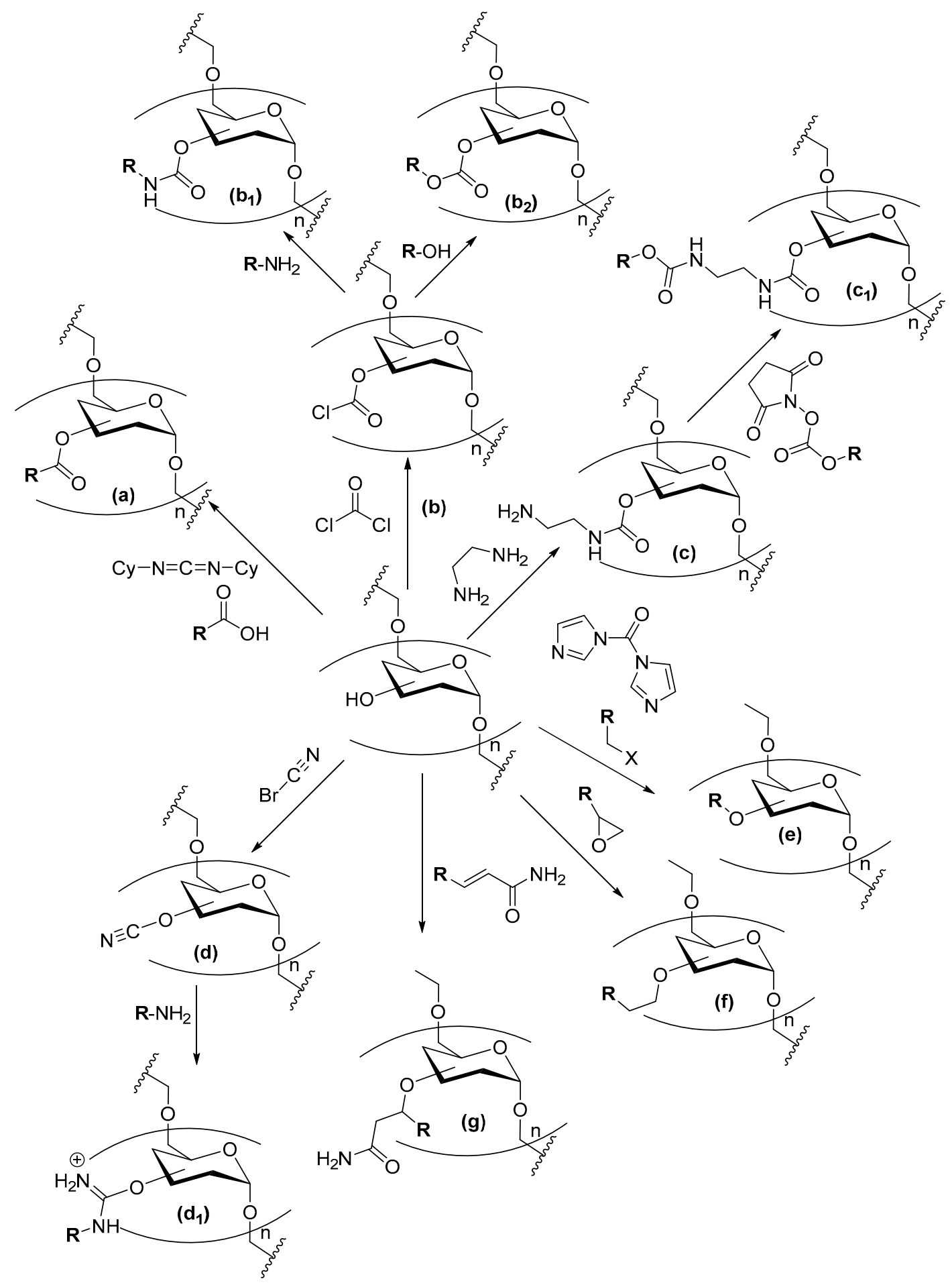

Figure 2. Conjugation of molecules to dextrans without opening the glucopyranose ring: via activation with $N, N$-dicyclohexylcarbodiimide (a); by activation with phosgene and creating carbamate $\left(\mathbf{b}_{1}\right)$ or carbonate $\left(\mathbf{b}_{\mathbf{2}}\right)$ linkages; by activation with carbonyldiimidazole and ethylenediamine for dextran derivatives possessing pendant amino groups (c), and coupling with succinimidyl-activated derivatives $\left(\mathbf{c}_{\mathbf{1}}\right)$; by cyanogen bromide activation $(\mathbf{d})$, and a subsequent isourea-type bonding $\left(\mathbf{d}_{\mathbf{1}}\right)$; by irreversible etherification using halides (e), epoxides (f) or conjugated carboxamides (g). 
Thus, by using any of the previously mentioned methods, dextrans have been applied as macromolecular carriers for the delivery of drugs and proteins, aiming to increase the durability of several therapeutic agents inside the systemic circulation [86,91-95]. In fact, molecules with $\mathrm{Mw}<40 \mathrm{kDa}$ (half-life times of around $8 \mathrm{~h}$ ) are easily eliminated via renal filtering, whereas upon dextran-conjugation, the molecular weight of these prodrugs may be increased to values higher than $40 \mathrm{kDa}$, leading to increased half-lives. Consequently, these dextran-conjugated molecules would be retained in the liver and spleen, and then they would be gradually released through endo and exodextranase-catalyzed hydrolysis [96]. Moreover, dextrans have been also used for reducing the in vivo immunogenicity of proteins and enzymes [97,98].

Aside from this use, dextran-based materials are very useful for other biomedical applications [99] such as soft tissue reconstructions [100]. Additionally, iron-dextran derivatives can be used for treating iron-deficiency anemia [101,102], while dextran-sulphate coatings enhance the biocompatibility of inorganic systems [103]. Gene transfection is another biomedical area in which dextrans are advantageous [94]; in fact, because of the high biodegradability of DNA and RNA, it becomes mandatory to guarantee the safe delivery of gene vectors for providing successful gene therapies. Therefore, and due to the fact that viral vectors, although possessing excellent transfection efficiency, are also toxic and may lead to immunogenicity problems, the use of polycationic macromolecules is an excellent alternative vehicle for nucleic acid drugs [104-106]. Inside this area, dextran derivatives have been frequently used [107-110] because of their beneficial features, as recently reviewed by Huang and Huang [93]. Finally, it is worth mentioning the use of dextran-hemoglobin conjugates as blood substitutes for patients suffering from asthma or other hemoglobin-compromised conditions. These dextran derivatives not only increase the therapeutic efficiency by enhancing the binding and release of oxygen [111-114], but also prevent hemoglobin excretion (avoiding any kidney damage [115,116]), reduce the non-renal clearance of hemoglobin (therefore minimizing risks of tissue edema [117]) and reduce the auto-oxidation described for other hemoglobin-based oxygen carriers (reducing tissue and cellular toxicity [118]).

\subsection{Dextran Aldehyde (DexOx)}

The use of the periodate anion for oxidative cleavage of dextrans was first reported by L. Malaprade as early as 1928 [119]. Since then, this catalyst-free aqueous glycol (1,2-diol) cleavage has been known as Malaprade oxidation [120], whose mechanism is assumed to involve an acidic cyclic ester intermediate that decomposes to yield two carbonylic compounds, as shown in Figure 3.

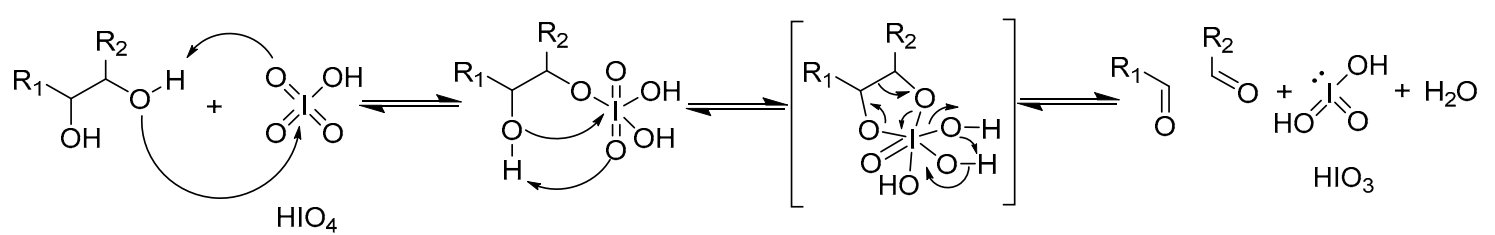

Figure 3. Malaprade oxidation of glycols.

This oxidation is carried out in aqueous solutions, although co-solvents such as methanol, ethanol or acetic acid may be used so as to increase the solubility of bulky organic substrates [120]. Initially, the Malaprade oxidation was used to determine the structure of different dextrans, which were completely oxidized; thus, the analysis of the degradation products was used to infer the structure of the starting polysaccharide [121,122]. When applied to dextrans, the corresponding dextran aldehyde, dexOx, is obtained [123]. The structure of the glucopyranoside rings possesses a vicinal diol, so that two different oxidizable bonds, between $C_{2}, C_{3}$ and $C_{4}$, are present (Figure 4).

In any case, the oxidation products contain an aldehyde group on $\mathrm{C}_{3}$, and two possible pathways will lead to another aldehyde rather at $C_{2}$ (Figure 2a) or $C_{4}$ (Figure 2b). Eventually, a second oxidation 
of both structures would lead to another dicarbonylic compound at $\mathrm{C}_{2}$ and $\mathrm{C}_{4}$; this can be easily monitored by the concomitant $\mathrm{pH}$ drop, as $\mathrm{C}_{3}$ would be transformed into formic acid [124].

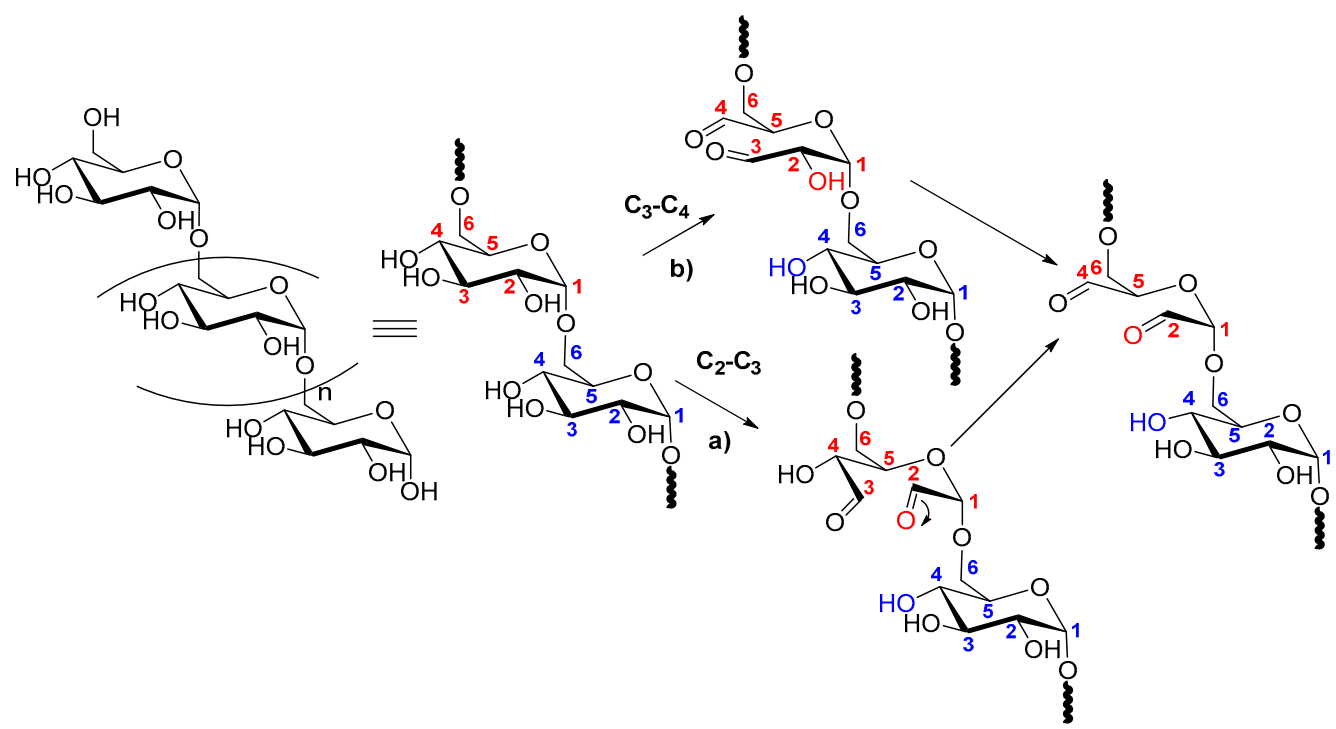

Figure 4. Possible structures of oxidized dextran (dexOx).

In the first oxidation step, the cleavage of the $\mathrm{C}_{3}-\mathrm{C}_{4}$ bond was described to be favored by 7.5-fold compared to the $\mathrm{C}_{2}-\mathrm{C}_{3}$ bond [125]; in any case, the aldehyde groups are not detected either with FTIR or NMR spectroscopy (except during the first stage of the oxidative cleavage), because of the reaction of the aldehydes with neighboring hydroxyl groups, leading to hemyacetals or hemialdals [125], as depicted in Figure 5.

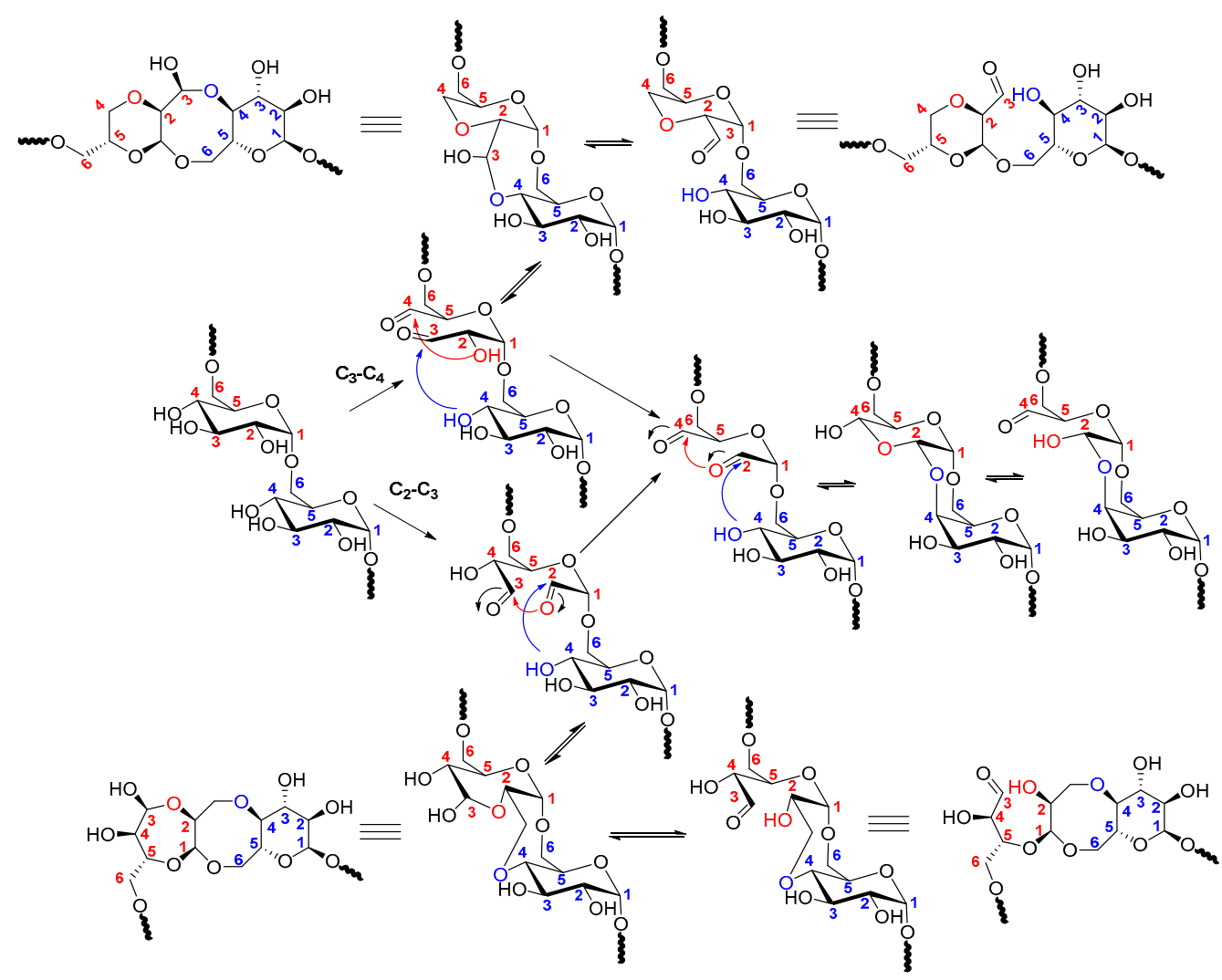

Figure 5. Formation of hemiacetal-type structures during oxidative cleavage of dextrans. 
These transient structures may interfere with the overall oxidative pathway, so the final oxidation degree can vary. Therefore, for mild oxidations (not generating formic acid), different colorimetric titrations have been used, assuming in all cases that both aldehydes will equally react with the titrating reagent. Nevertheless, Maia and coworkers [123], using a bidimensional NMR analysis of the condensation products of dexOx with different $N$-nucleophiles (adipic acid dihydrazide, tert-butyl carbazate or ethyl carbazate), confirmed that only one aldehyde per residue, the one at $C_{3}$, was reacting with the carbazates under mild acidic conditions, while the other one (mainly $\mathrm{C}_{4}$ ) is involved in the formation of more stable hemiacetals. It has been observed that hemiacetals might exist in a very narrow $\mathrm{pH}$ window, between 4.0 and 5.2; below that value, aldehydes are present, while for $\mathrm{pH}$ values over 5.2, enols and enolate ions can be detected [126]. Interestingly, when the oxidation of dextran is carried out in the presence of DMSO, the second oxidation is not detected, because the formation of the hemiacetals is strongly promoted [127]. Hence, it can be inferred that the determination of the oxidation degree of dextran is not a trivial question, and its control is crucial for the efficient design of the intended modification methods [99]. For this purpose, the amount of aldehyde groups has traditionally been determined by spectrophotometric (using carbazates $[128,129]$ or dinitrosalicilic acid [130]) or potentiometric [131] titration.

\subsection{Coupling of Enzymes to DexOx}

The usual methodology for coupling proteins and other biomolecules to dexOx is by reacting the pendant aldehyde groups of dexOx with nucleophilic residues, mainly amine groups of lysine residues, to create reversible imine (Schiff base [132]) linkages, at alkaline $\mathrm{pH}$ values (from 9 to 10) [133,134]. This condensation generates a water molecule per iminic bond formed (Figure 6), and in aqueous media the equilibrium is shifted towards the hydrolysis of the $\mathrm{C}=\mathrm{N}$ bond, returning to the starting substrates (carbonyl and amine). However, there is some evidence suggesting that some cycles may be involved in the reaction between amino groups and dexOx, making the coupled product more stable.

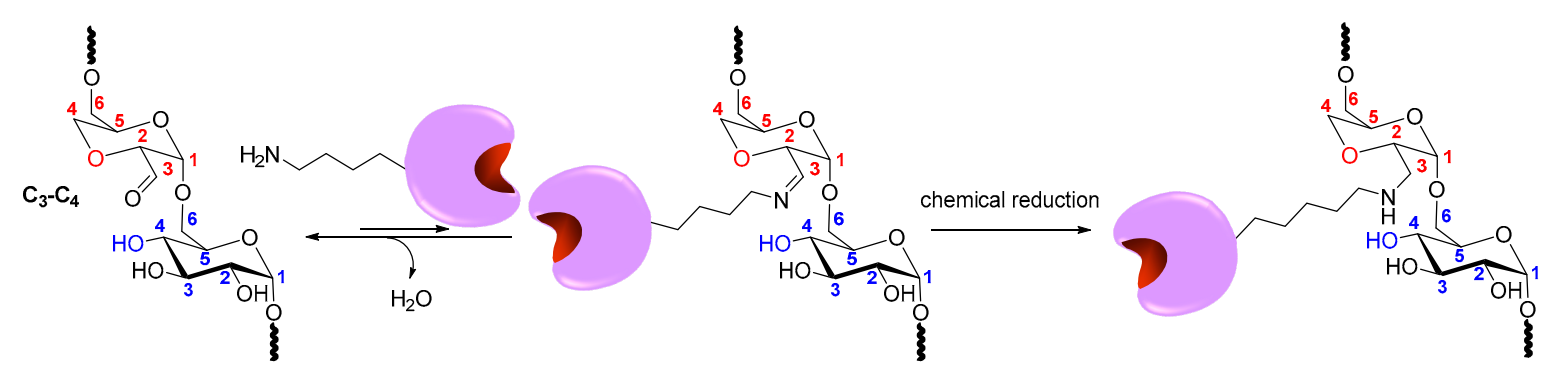

Figure 6. Coupling of dexOx with proteins via reductive amination.

The usual way to stabilize the labile azomethine group is to reduce it to a secondary amine bond, so that the overall process (condensation and reduction) is called reductive amination [135]. There are different reducing agents that can be used, such as sodium cyanoborohydride (ideally, for $\mathrm{pH}$ values between 6 and 8) and different borane complexes [136], specially $\alpha$-picoline borane [137-141]. Sodium borohydride could be also used for reducing the imine, but, as it is 5-fold stronger than sodium cyanoborohydride, it could directly reduce the aldehyde groups (avoiding the condensation with the amine) or even the disulfide bridges, leading to enzyme denaturation [134]. Unexpectedly, Ruzicka et al. reported that the reduction step may not be necessary when forming the imine linkage at high $\mathrm{pH}$ values, as long as proteins are not released from the carrier even upon treatment with $0.1 \mathrm{M} \mathrm{HCl}$ [142], although these results were obtained at the microliter scale. Finally, a recent paper by Chimpibul et al. [143] proposed a scission as a mechanism for dexOx when reacting with amines, based on a Maillard reaction with glycine. 


\section{Aplications of Dextran and DexOx in Biocatalysis}

\subsection{Glycosylation of Enzymes and Promotion of Intramolecular Crosslinkings}

One of the applications of dexOx has been the artificial glycosylation of free or immobilized enzymes. The large size of the dextran molecule will produce a large change in the physical and chemical properties of the protein surface with a minimal chemical modification of the enzyme, therefore allowing an alteration in many of the functional properties of the proteins.

Although dexOx is a random coil molecule with scarce rigidity, some authors tried to increase the enzyme rigidity using intramolecular covalent crosslinking. For instance, soluble cellulase from Aspergillus niger was modified using dexOx, with a significant improvement in enzyme stability versus inactivation, both thermal or mediated by sodium dodecylsulfate [144]. In another example, dextran sulfate was oxidized with periodate, and this polysaccharide was employed to modify an $\alpha$-amylase from Aspergillus oryzae, maintaining the enzymatic activity at a $\mathrm{pH}$ value lower than that the one for the non-modified enzyme [145]. These same authors detailed the conjugation of horseradish peroxidase with dexOx, also reporting an improved enzyme stability in thermal and $\mathrm{pH}$ inactivation [146]. Maksimenko et al. $[147,148]$ disclosed a hyaluronidase that was modified with dexOx using a very intense crosslinking (the amine modification degree was $96-100 \%$ ), which was practically not inhibited by heparin, in contrast to the behavior observed for the unmodified counterpart. Similarly, this hyaluronidase-dexOx conjugate showed a higher activity in the presence of caotropic agents, allowing us to enlarge the range of $\mathrm{pH}$ in which the enzyme was active; thus, heparin inhibition slightly differed between $\mathrm{pH} 5.5$ (1.5-fold inhibition) and 7.5 (1.2-fold inhibition), while the ionic strength of the reaction medium only slightly influenced the enzymatic activity.

In some other classical examples, urease was modified using dexOx and its functional properties were improved [149]. In another research, papaya proteinase was modified with dexOx- cysteine for increasing the number of sulfhydryl groups in the enzyme environment, enabling an increase in the activity of the composite [150]. The stabilization of dexOx-Cysteine-modified papaya proteinase was explained by two reasons: firstly, the rigidification of the biocatalyst structure by the crosslinking produced an increased stability; secondly, the enzyme was stabilized by the prevention of protein association via thioldisulfide exchange reaction. In another research effort, glucoamylase from Aspergillus niger was modified with dexOx, trying to get a high crosslinking degree that permitted enhancing the enzyme stability [151]. In order to increase the dexOx crosslinking of the enzyme, it was aminated (aminating both the sugar chains of the protein and the carboxylic residues of the enzyme), promoting a further increase in enzyme stability and activity at high temperatures. Similarly, superoxide dismutase modified with dexOx was more thermostable than the unmodified enzyme [152], and this modified enzyme also exhibited a better antifibrous activity in experimental silicosis [153].

Sometimes, the dexOx modification is carried out on previously immobilized enzymes, with the aim of stabilizing an area of the enzyme not involved in the immobilization. In a first example, the lipase B from Candida antarctica was initially immobilized on octyl-agarose via interfacial activation, and subsequently modified through amino terminal residue using dexOx [154]. This one-point modification altered the secondary structure of the enzyme, modifying its functional properties, making the modified enzymes more stable, active, and selective toward different substrates than the unmodified lipase B from Candida antarctica. In another paper [155], lipases from Thermomyces lanuginosus and Rhizomucor miehei and lipase B from Candida antarctica, immobilized via interfacial activation on octyl agarose [156,157], were aminated using the carbodiimide route $[158,159]$. Then, they were submitted to an intense crosslinking with dexOx, reporting a large increase (ranging from 4 up to 250-fold, depending on the enzyme) on the stability for these immobilized lipases (Figure 7). This was attributed to the formation of an intense intramolecular covalent crosslinking [155]. 


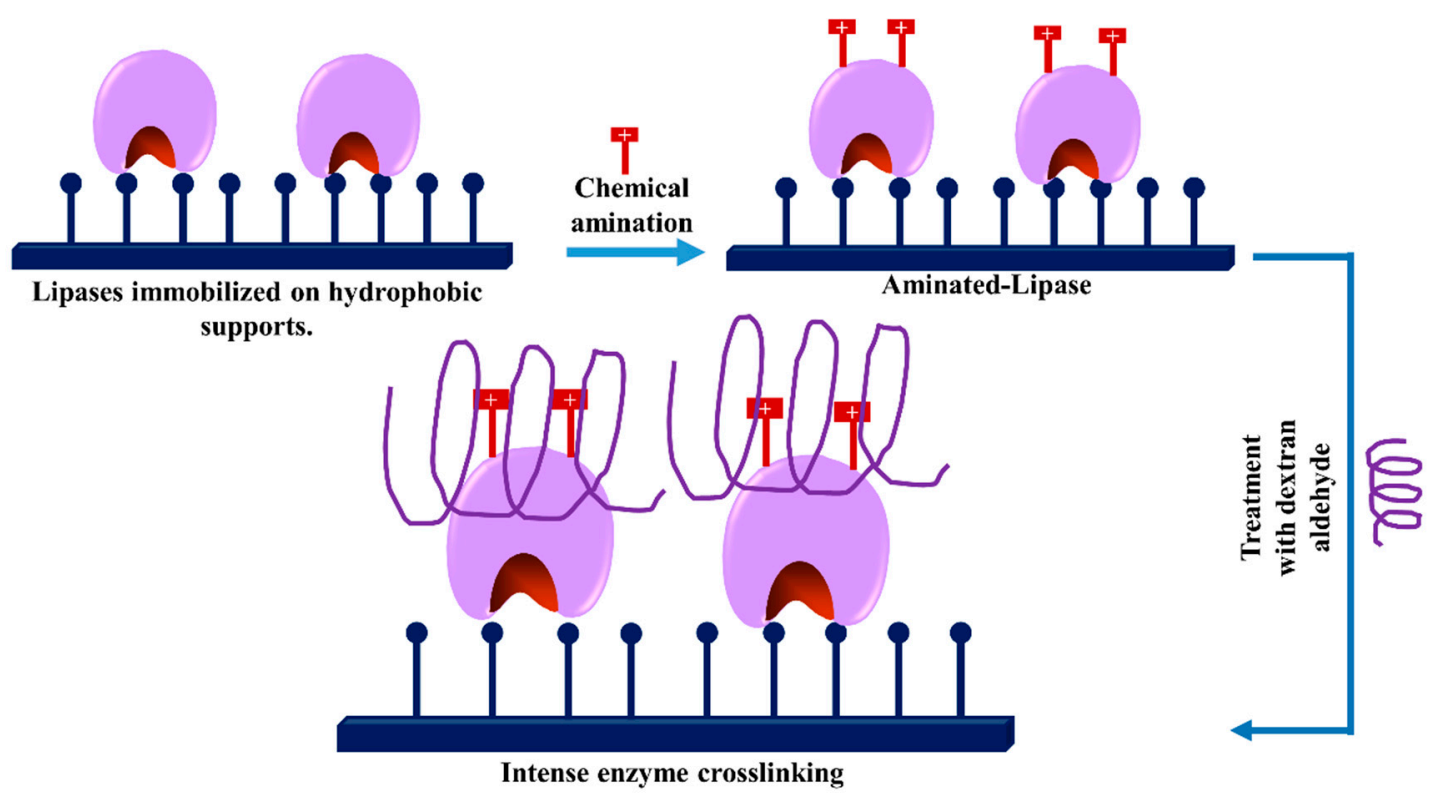

Figure 7. Stabilization of immobilized lipases by amination and further intense intramolecular crosslinking with dexOx.

Enzymes become inactivated when they interact with hydrophobic interfaces [160], such as gas bubbles [161,162] or organic solvents [163-166]. It is well known that by immobilizing them in porous supports, this inactivation can be prevented [167], while soluble enzymes may be readily inactivated by these very undesirable interactions. Thus, it has been proposed that the coating of the enzyme molecules with large polymers may solve this limitation, as the hydrophobic interface cannot reach the protein core due to the shell formed by the polymer. This has been exemplified using ionic polymers [168-170], which will coat the surface via ionic interactions, or dexOx, which will cover the surface of the enzymes via covalent bonds. Thus $D$-amino acid oxidase, glucose oxidase and trypsin were coated with dexOx, reporting and increase in stability of the immobilized enzymes in the presence of hydrophobic interfaces [171]. In another paper, cellulase from Aspergillus niger modified with dexOx was described to be more stable in the presence of air bubbles (residual activity of about $50 \%$ for 4 h) [144]; correspondingly, horseradish peroxidase modified with dexOx was not only more stable and active than the free enzyme in presence of an organic-aqueous interface, but also became less prone to suffer inhibition in the presence of heavy metal salts and various denaturing compounds [172]. This stabilization versus interaction with hydrophobic interfaces was later extrapolated to the enzymes immobilized on nonporous nanoparticles (Figure 8). Glucose oxidase immobilized by multiple covalent attachments in non-porous nanoparticles was inactivated by interaction with hydrophobic interfaces (e.g., gas bubbles) [173], because the immobilized enzyme remains exposed to the external interfaces. This inactivation does not occur when the enzyme was immobilized (even by a single point) in porous supports. However, the coating of the enzymes with dexOx when immobilized on non-porous nanoparticles enabled us to overcome this inactivation problem [173] (Figure 8).

A dexOx molecule can carry many molecules to be used in the modification of a protein. Taking advantage of the multifunctionality and large size of dexOx, it has been utilized to introduce a high number of the target molecules (attached to the dextran) while promoting a scarce chemical modification of the protein. For example, this has been used to raise antibodies versus small molecules, as small molecules are unable to raise an immunogenic answer. When antibodies for these molecules are required, they must be attached to large molecules, usually proteins like keyhole limpet hemocyanin and these antigen-modified protein molecules are injected in the host mammal [174-177]. Keyhole limpet hemocyanin protein coated with dexOx may be used as a protein carrier to promote immunoresponse versus low-size antigens, enabling us to modify this protein using many aminated antigens. These molecules were used to raise high concentrations of antibodies versus the aminated antigens [178]. 


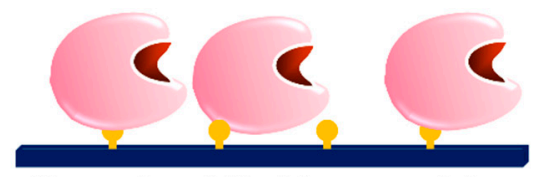

Enzyme immobilized in nanoparticles

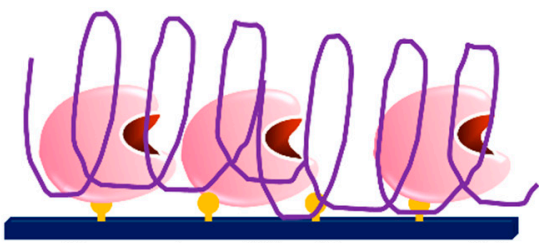

Enzyme immobilized in nanoparticles and coated with dexOx

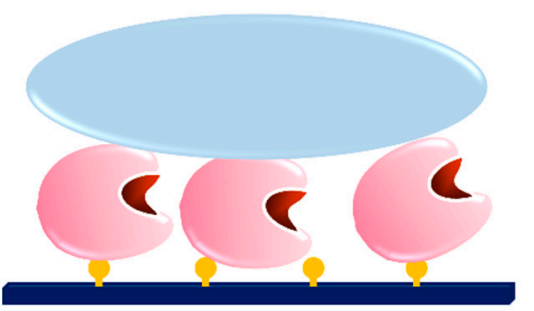

Inactivation by interaction with gas bubbles
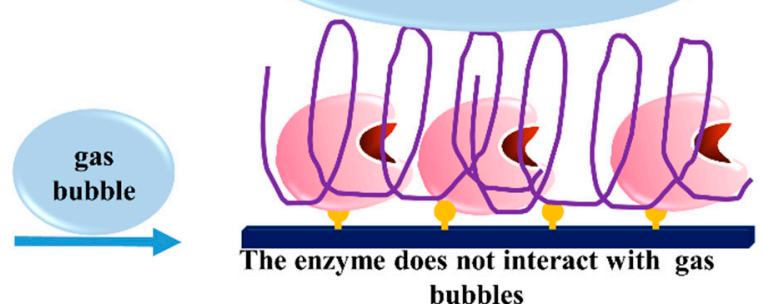

Figure 8. Coating of enzymes immobilized on non-porous nanoparticles with dexOx protects the enzyme from interactions with hydrophobic surfaces.

In other cases, as the size of dexOx is larger than that of the enzyme, several different enzyme molecules can be immobilized in one dextran molecule. For example, many molecules of horseradish peroxidase and biotin were attached to large dexOx molecules to build a macromolecule probe [179]. In another example, some molecules of ovomucoid proteinase inhibitor from duck egg white were attached to dexOx [180]. While the number of inhibitor molecules attached to the dextran does not have any effect on the inhibitory activity of the composite, a strong negative effect on this capacity depending on the number of dextran-ovomucoid bonds was observed [180]. Moreover, when few ovomucoid molecules are attached to dexOx, the protein-protein interactions are minimal, as the polymeric chain prevents the formation of protein aggregates.

\subsection{Dextran Aldehyde in the Preparation of Crosslinked Enzyme Aggregates (CLEAS)}

Prof. Sheldon proposed in 2000 a new enzyme immobilization protocol without the use of any carrier, the crosslinked enzyme aggregates (CLEAs) [181]. This strategy is based on the aggregation of the enzyme molecules intended to be immobilized by adding some precipitant reagents, and a subsequent chemical crosslinking used to create water-insoluble aggregates; so, these aggregates become physically stable and cannot be re-dissolved when the precipitant reagent is washed away [182-184]. The strategy has many advantages compared to the crosslinked enzyme crystals (CLECs), regarding the purity requirements (maximum purity for CLECs, no requirement for CLEAs), possibility of coimmobilizing enzymes or enzymes and polymers, etc. $[167,182,185]$. While finding conditions where an enzyme solution may precipitate maintaining high levels of activity are fairly easy, the crosslinking step is the bottleneck of the CLEAs preparation in many instances. The crosslinking mechanism generally involves reactive primary amino groups of the protein (epsilon-amino group of Lys residues and $N$ terminus); some proteins may not possess a high amount of this residue on the surface, so that in these cases, the CLEA preparation is not straightforward. This has been solved by using a feeder (which can be a Lys-rich protein [186-193] or an aminated polymer [194,195]), by a chemical amination of the enzyme [196-198] or by using an alternative crosslinking group in the enzyme (e.g., carboxylic groups) [199]. Usually, the crosslinking reagent is glutaraldehyde [182,184] due to its good properties as crosslinking reagent $[200,201]$. On the other hand, some researchers have shown that dexOx can alternatively be used in the crosslinking step due to its large size and the high number of aldehyde 
groups. In this way, the lipase from Burkholderia cepacia was immobilized using CLEA technology using both glutaraldehyde and dexOx as a crosslinker [202]. The use of aldehyde dextran allowed for obtaining lipase derivatives with a higher activity, although with a lower stability, very likely due to the higher flexibility of dextrans.

Anyhow, the use of glutaraldehyde as crosslinker agent is not suitable when any Lys residue is critical for enzyme activity/stability, as glutaraldehyde can reach those amino groups hidden in pockets in the enzyme. In this case, the large size of dexOx may be a smart solution so as to avoid the undesired modification of critical groups located in enzyme pockets.

Thus, CLEAs of hydroxynitrile lyase, alcohol dehydrogenase, penicillin G acylase and different nitrilases from two different sources were prepared using dexOx as a crosslinking reagent and the results were compared to those obtained using glutaraldehyde [203]. In most instances, higher immobilization yields were obtained using this multifunctional polymer when compared with glutaraldehyde. This dexOx crosslinking reduced the losses in functional active sites; for instance, CLEAs of formate dehydrogenase from Candida boidinii (very useful for $\mathrm{NADH}$ regeneration and $\mathrm{CO}_{2}$ reduction) were produced using dexOx, reporting a higher activity and stability compared to that obtained with glutaraldehyde [204].

A general problem associated with CLEAs is the existence of strong substrate diffusional limitations, mainly if the enzyme activity is very high or when using large substrates. In this sense, another positive effect of using dexOx instead of glutaraldehyde is the generation of larger pores, therefore reducing these substrate diffusional problems [205-208]. For instance, CLEAs of $\beta$-mannanase were prepared using dexOx; scanning electron microscopy confirmed the porous structure with low steric hindrances, leading to a 16-fold increase of the enzymatic activity when compared to the CLEA crosslinked with glutaraldehyde [209]. In another paper, CLEAs of $\alpha$-amylase were obtained using many different polysaccharides (agar, chitosan, dextran, and gum arabic) previously oxidated with periodate as croslinkers. The best results were those obtained using ammonium sulphate as precipitant agent and cross-linked by using dexOx, doubling the activity obtained using glutaraldehyde; CLEA stability was also higher when using dexOx [210]. Similarly, $\alpha$-amylase from Aspergillus oryzae and glucoamylase from Aspergillus niger were used to produce CLEAs, and once again the crosslinking with dexOx furnished an enzymatic derivative of the $\alpha$-amylase more active ( 3 -fold) than that prepared with glutaraldehyde [211]. However, no activity recovery was observed for the glucoamylase, due to the enzyme affinity for dextran. Finally, $\beta$-glycosidase from bovine liver was utilized to produce CLEAs that reportrfthe highest recovered activity when using dexOx [212].

Some papers show other alternatives to the use of dexOx as a crosslinker agent. Thus, several complexes of $\mathrm{Ru}(\mathrm{II})$-diimine (with $4,4^{\prime}$ - or 5,5'-dicarbaldehyde-2,2'-bipyridine and 5'-carbaldehyde-1,10-phenanthroline) were used to crosslink cytochrome P450 BM3 variants showing peroxygenase activity, reporting improved results when compared to those achieved with dexOx or glutaraldehyde [213]. This higher stabilization was attributed to the presence of a modular number of aldehyde groups and a rigid framework of the new crosslinker, leading to a better rigidification of the enzyme structures compared to glutaraldehyde or dexOx.

\subsection{Dextran Aldehyde for Controlling the Adsorption of Biomacromolecules on Support Surfaces}

The modification of some supports with dexOx can greatly increase their biocompatibility and hydrophilicity. It has been described that the modification of silicon surfaces with dexOx (using different sizes and oxidation degrees) reduces the adsorption of proteins on the support surface, being the oxidation percentage of the dextran the key parameter [214]. This modification confers antifouling properties on the new materials.

Additionally, dextrans are extremely flexible and, after reduction to convert their aldehyde groups into hydroxyl groups, they become hydrophilic and inert macromolecules. Thus, their application as surface coatings can prevent the multipoint interaction of biomacromolecules with the support surface, while their random coil nature still permits the one-point interaction. This has a great relevance in 
affinity chromatography, where a strong one-point interaction with the target protein (rather than any multipoint interaction of other proteins leading to unspecific adsorption) is highly desirable [215-217]. In this sense, one of the most successful reports is the design of Immobilized Metal Chelate Affinity (IMAC) columns to specifically adsorb proteins with one poly-His tag, while not adsorbing any native proteins. The poly-His tagged protein can become immobilized via a double interaction between two His groups in the tail and one chelate in the support, while the native proteins need to involve several His residues for the immobilization interacting with several chelate groups in the support [218-223]. Therefore, using a lowly activated support, the poly-His tagged enzyme is largely the only one which will get immobilized, while native proteins will not be adsorbed [224]. Unfortunately, this means a very low adsorption rate. A rational proposal to overcome this drawback is to coat the IMAC support with dexOx in order to avoid the multipoint adsorption while the one point adsorption capacity of the support remains almost intact [225] (Figure 9). By using this methodology, the measured immobilization rate was around $80 \%$ compared to the adsorption rate for the naked supports, while the specificity was similar to that obtained, with supports having a 10-fold lower superficial density than the IMAC groups, enabling the (almost) fully selective adsorption of the target enzyme. The blocking design was critical; a double modification using dextrans with different sizes was required to get optimal results [225].

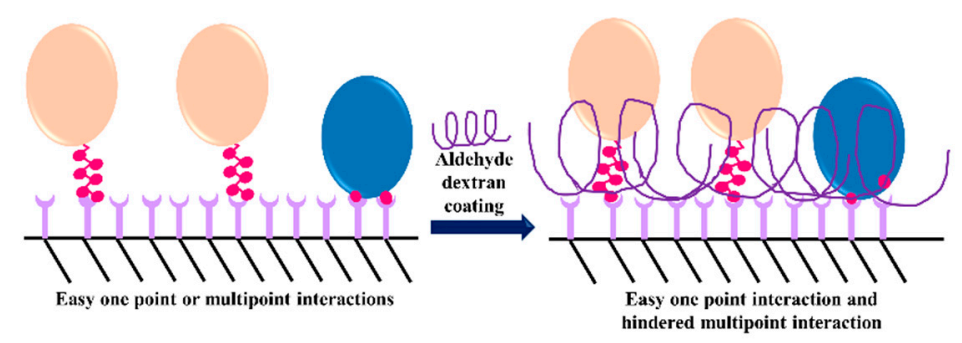

Figure 9. Improved selectivity of highly activated IMAC supports by dexOx coating.

Another problem commonly presented when using highly activated supports for enzyme purification, is the extremely high adsorption strength between large proteins (that is, possessing many groups able to interact with the support) and activated supports. In this scenario, the ulterior release of the enzyme may be too difficult due to the establishment of a very intense multipoint protein-support interaction, even if an initial selective adsorption via the poly His tag has been achieved. This complication has been also solved using this dexOx coated supports [225]. Considering that most enzyme adsorptions on support surfaces are based on multipoint interactions, their prevention by similar techniques can have a very positive effect on the specificity of the biomacromolecules adsorption processes on a support [226].

In another example, an ion exchanger capable of adsorbing only small proteins was prepared. This was achieved by initially coating the support with a moderately large protein (bovine serum albumin), so that the only available space for adsorbing another protein molecules was the one placed between bovine serum albumin molecules [227]. However, the first results were quite disappointing, as most proteins from milk whey became adsorbed, as a consequence of the direct interaction of these proteins with the immobilized bovine serum albumin molecules. This conclusion was derived by comparing the previous system with the one using a support of just bovine serum albumin immobilized on an inert surface (glyoxyl-agarose) $[227,228]$. Thus, the immobilized bovine serum albumin was coated with dexOx, and it was observed that their adsorption capacity was suppressed. The same strategy using an ion exchanger support permitted us to have a fully selective matrix for small proteins [227], so that small beta-lactoglobulins and alpha-lactalbumin from dairy whey were specifically adsorbed, while other larger proteins contained in the whey (IgGs, for example) remained in the supernatant (Figure 10). 


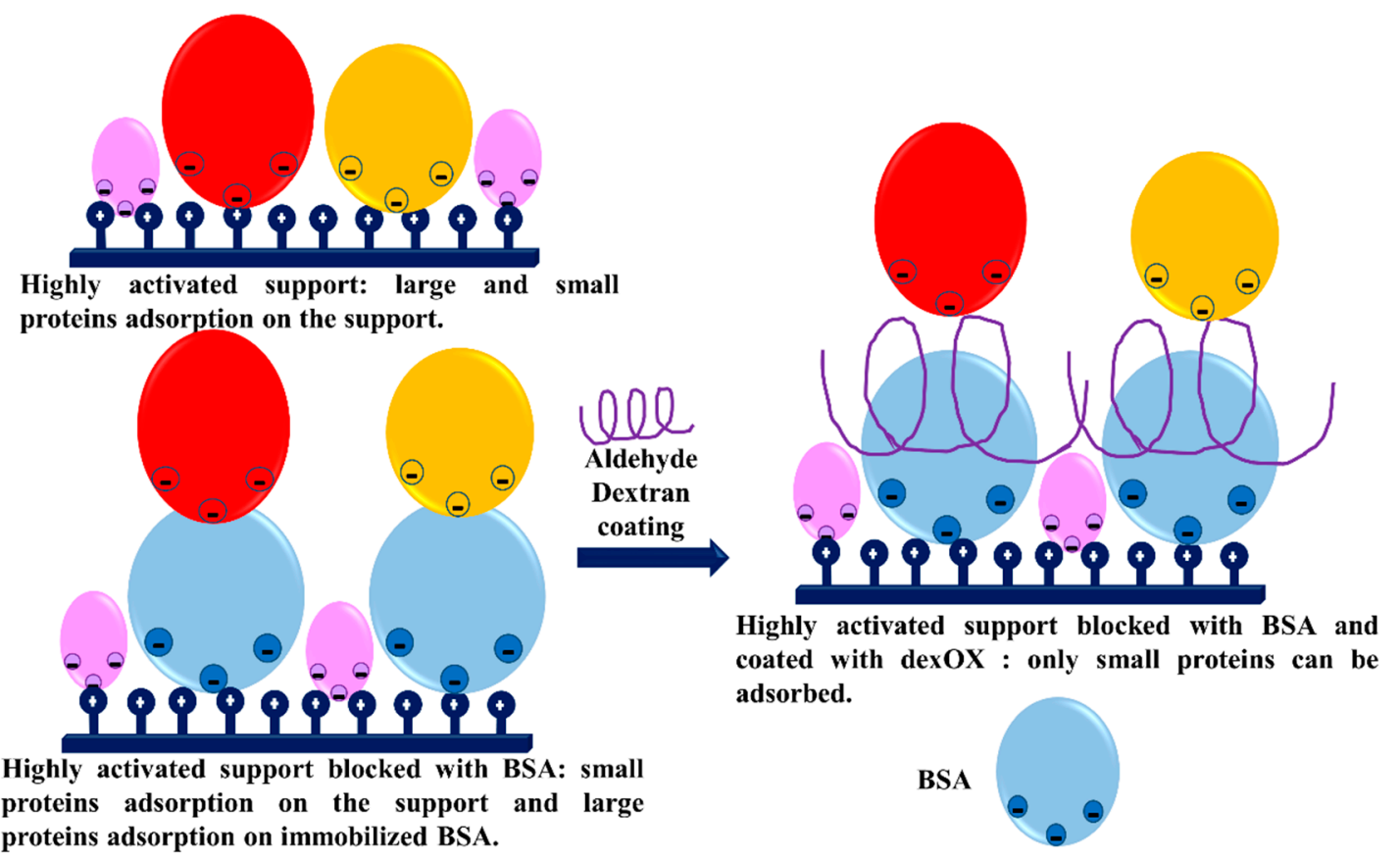

Figure 10. Selective ion exchange of small proteins using supports coated with BSA modified with dexOx.

Another useful application for the control of unspecific adsorption of biomacromolecules on the support surface is in the field of biosensors. In this case, an ideal biosensor should exclusively adsorb the target molecule, while leaving other biomacromolecules in the supernatant (including reading antibodies, for example) [229].

Immobilization of antibodies on aminated supports is a very popular method to produce immunosensors. Following this methodology, the immobilization using the oxidized sugar chains of antibodies as spacer arms keeps almost full recognition capacity of the immobilized immunoglobulin, regardless of the size of the antigen [230]. However, this strategy presents some disadvantages; first of all, this cationic support may lead to a non-specifically protein adsorption via anion exchange [230-235]. In fact, this support was able to adsorb not only the desired antibody but also many proteins presented in the sample, including the reading antibody (Figure 11). The direct blocking with dexOx was not efficient enough; actually, it prevents unspecific adsorption on the support surface but at the same time it produced a decrease in the recognition capacity of the antibody, because the terminal amino groups of the antibodies are near to the recognition area (Figure 12). However, by using aspartic acid-dexOx, the formation of a "smart coating" is achieved, as this reagent is mainly directed towards the support aminated surface while hardly modifying the antibody, and is capable of eliminating the unspecific proteins adsorption while maintaining more than $80 \%$ of the initial recognition capacity of the immobilized antibody [236] (Figure 13).

The second problem observed using aminated supports and the sugar chains as spacer arms in the antibody immobilization was the drastic drop of the biosensor activity under storage conditions, even at $4{ }^{\circ} \mathrm{C}$ [236]. Despite this, it remained possible to recover the initial immunoactivity by incubating the biosensor in a high concentration of buffering solutions, suggesting that this problem was derived from the collapse of the antibody on the support aminated surface (the sugar chain is a long and flexible spacer arm which cannot prevent that from occurring). The coating of the support with aspartic acid-dexOx also prevented this undesired effect [236] (Figure 14). 


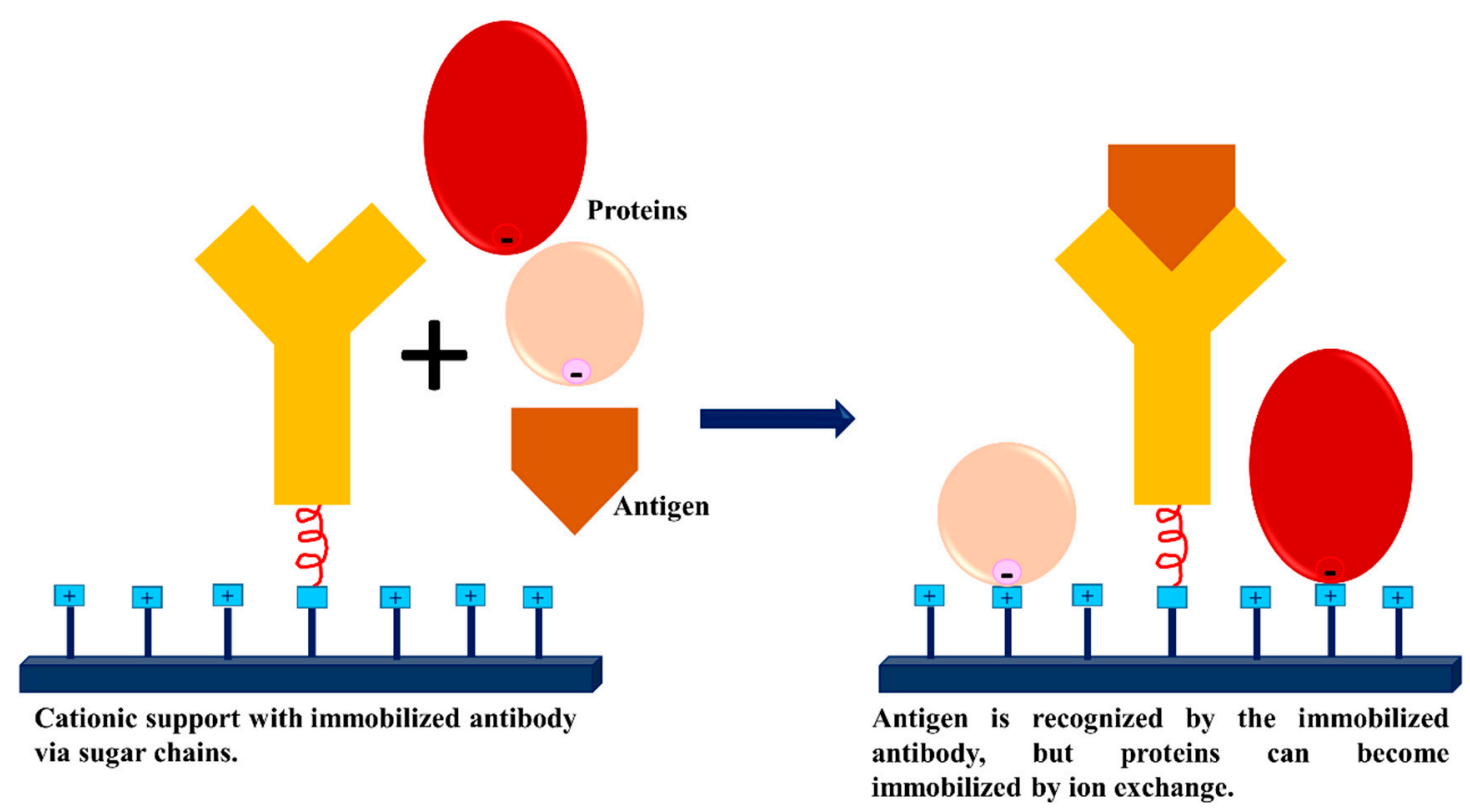

Figure 11. Antibodies immobilized on aminated supports: good functionality by many proteins can become unspecifically adsorbed on the support.

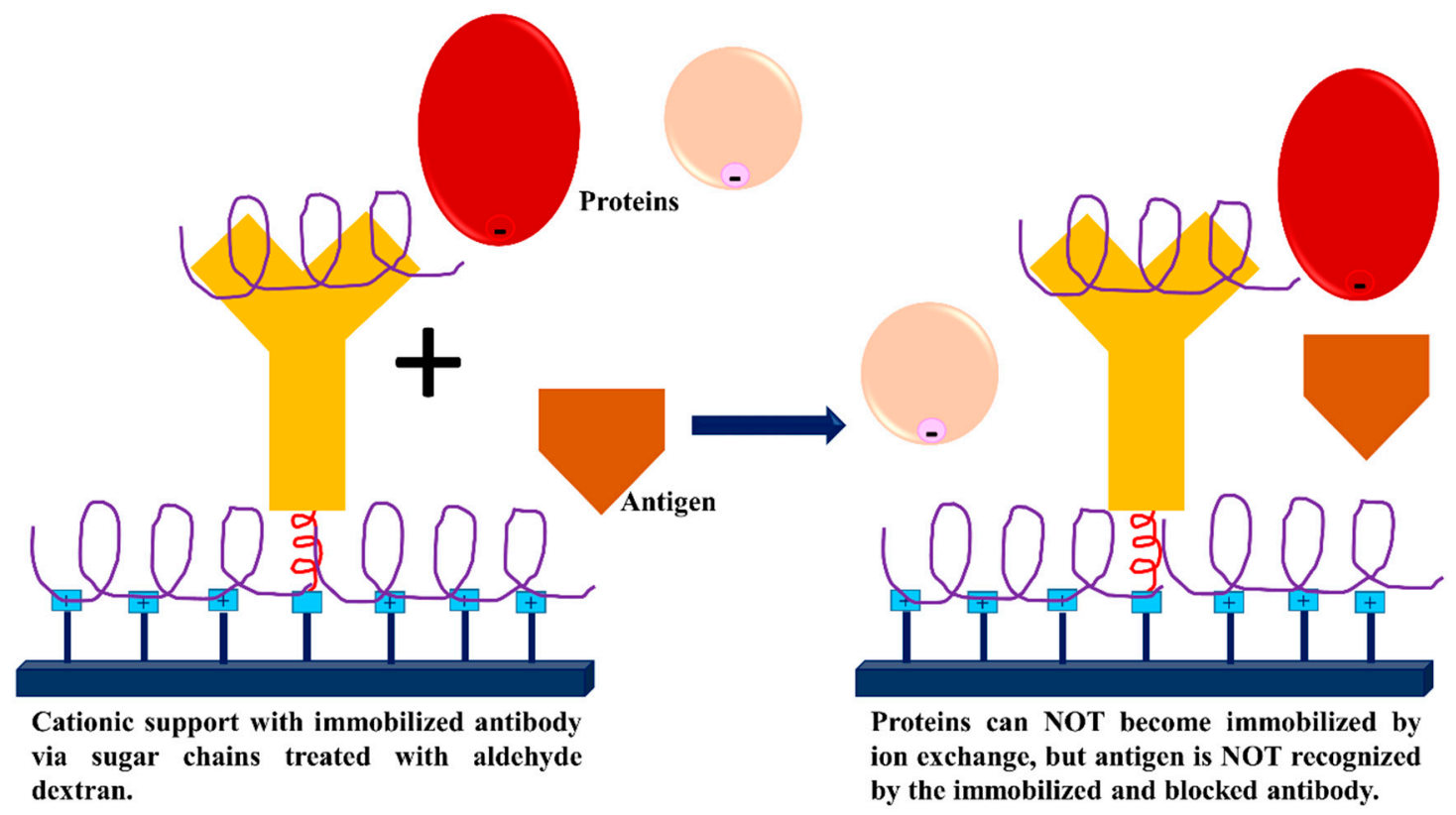

Figure 12. Antibodies immobilized on aminated supports coated with dexOx the unspecific adsorption of proteins in the support is prevented, but the function of the antibody is also eliminated.

In another example, both dexOx and aspartic acid-dexOx were used to immobilize aminated DNA probes on aminated supports [237]. This time, aspartic acid-dexOx was simultaneously the spacer arm where the aminated DNA probes were immobilized (via the aldehyde groups) and the blocking reagent (the dextran chains promoting steric hindrances and the aspartic groups enabling the partial blocking of the amino groups in the support surface). The naked aminated support was able to unspecifically adsorb DNA fragments of any length. This was avoided using the coating with the aspartic-dextran [237]. On the other hand, the fast detection of G group Streptococcus and Staphylococcus aureus was described based on the affinity chromatography involving the interaction of proteins A and G of the bacterial cell wall with the Fc fragment of human IgG [238]. Similarly, the modification with dexOx reduced nonspecific adsorptions and interaction problems. 


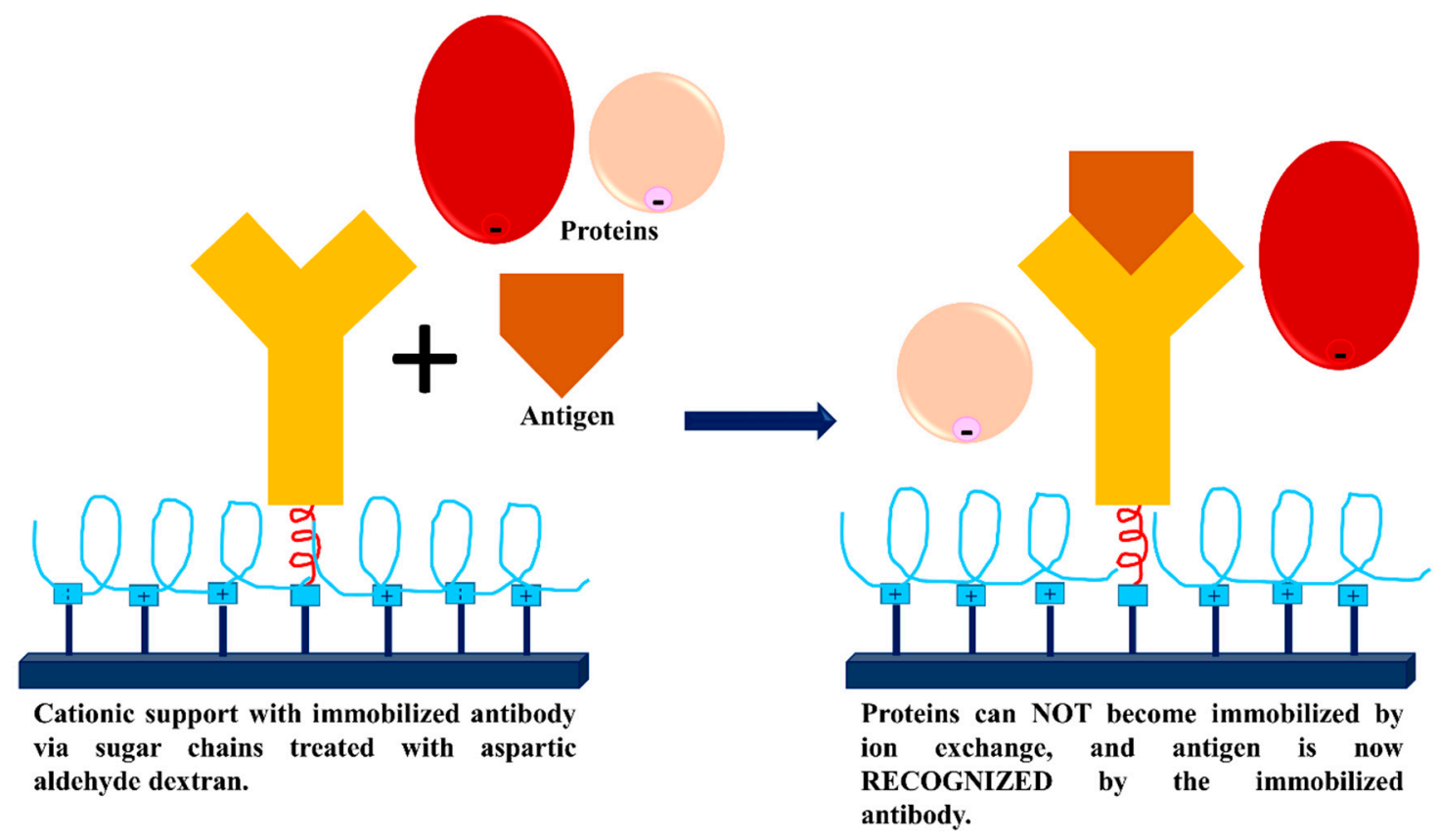

Figure 13. Antibodies immobilized on aminated supports coated with ASP-dexOx: selective coating of the support permit to maintain functionality of the immobilized antibody and avoid no specific adsorption of proteins on the support surface.

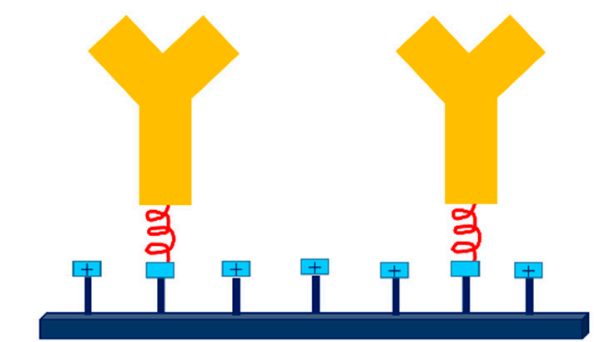

Cationic support with immobilized antibody via sugar chains

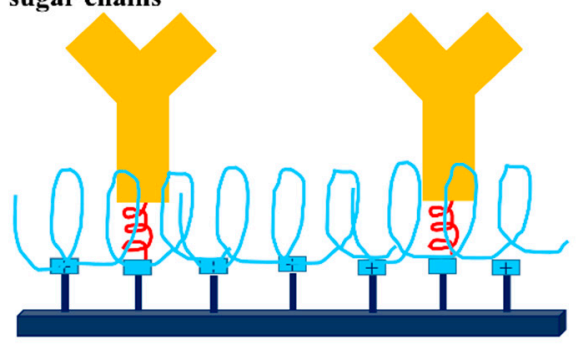

Cationic support with immobilized antibody via sugar chains treated with aspartic aldehyde dextran

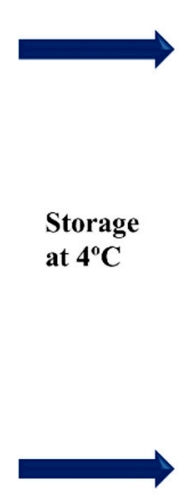

Figure 14. Antibodies immobilized on aminated supports via the sugar chain are inactivated by collapsing on the support surface. This is prevented by coating of the surface with ASP-dexOx.

Not always the modification of a support surface with dexOx produces a more inert surface: It is necessary to make the modification in a proper way. In fact, the adsorption capacity of a support may even increase if the support modification with dexOx is not properly designed. For instance, dextran modification of polydimethylsiloxane particles increased the adsorption of fibrinogen and albumin even though the contact angle of the support surface was reduced from $109^{\circ}$ to $80^{\circ}$ (showing the support surface hydrophilization) [239].
Activity drops due to the antibody collapse of the support surface.

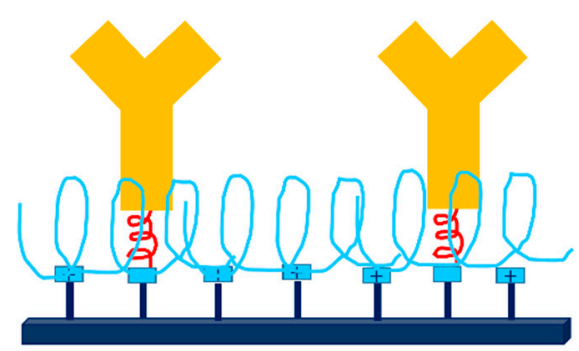

Activity does NOT CHANGE due to aspartic aldehyde dextran prevention of the antibody collapse of the support surface 


\subsection{Dextran Aldehyde as Active Group and Spacer Arm in the Support}

In some instances, DexOx has been used as an alternative active group for different supports in some instances, because their aldehyde groups can react with amine groups of the proteins and supports. In this sense, lipase from Candida rugosa was immobilized on a macroporous resin using dexOx as active group, and the biocatalyst was used to produce oleyl oleate via esterification in a solvent-free system [240]. The best results were obtained using $20 \mathrm{KD}$ dexOx as spacer arm. In another paper, the use of dexOx as spacer arm was applied to an electrospray production of immobilized protein microarrays (on aluminized plastic), leading to a highly advantageous devices showing the highest sensitivity and the lowest noise [241]. These positive results are caused by the mobility of the molecules attached to the dextran and also by a reduction on the adsorption of other non-desired proteins via multipoint interactions with the support. Similarly, trypsin immobilization on hydrophobic polyester fleece FO 2413 via dexOx and bovine albumin reported the highest proteolytic activity compared to other spacer arms [242]; the authors explained the results attending to the decrease of the steric hindrance and some environmental effects promoted by the immobilization surface. Thus, bovine serum albumin was useful fordecreasing negative effects of the hydrophobic support, but as a rigid polymer, the enzyme molecules immobilized on it did not have mobility. The use of dextran as spacer arm conferred more mobility on the immobilized molecule. This increased the recovered activity, but it also allowed the interaction of the immobilized trypsin molecules with the hydrophobic surface if the coating was not adequate [242]. In another stimulating research study, a comparison was drawn between two ways of using dexOx for enzyme immobilization. Hence, a $\beta$-glucosidase was coated with dexOx and later this composite was immobilized on aminopropyl silica; alternatively, aminopropyl silica was modified with dexOx and later $\beta$-glucosidase was immobilized on this support [243]. The highest stabilization was achieved when the enzyme was initially modified with dexOx, maybe because this strategy permitted the stabilization of the multimeric structure of the enzyme, or as stated by the authors, because this protocol made the $100 \%$ of the enzyme surface available for the enzymatic immobilization [243].

However, in other instances, the use of dexOx as spacer arm and reactive group takes advantage of other specific features of dextran. One of the highest advantages of using dexOx as the spacer arm is related to its structure (random coil polymer), which confers a high mobility to any molecule attached to it, provided that the dextran is attached to the support surface by just a few bonds and to the enzyme by, ideally, just one linkage (Figure 15). Moreover, dextran is very hydrophilic and mainly inert after reduction with sodium borohydride, avoiding any undesired enzyme-spacer arm interaction after immobilization. For large-sized substrates, if short spacer arms are used, only those enzyme molecules properly oriented will remain active, while for dexOx-immobilized protein molecules, most of them will be capable of converting the substrate (Figure 15). In this sense, dexOx was used to activate a silicate carrier which was subsequently employed to attach lysozyme, maintaining some activity even in the lysis of a substrate as large as a bacterial cell wall [244]. On the other hand, free $\beta$-amylase was modified with dexOx, reporting an activity decrease as a result of steric hindrances in the vicinity of the catalytic site (show by an inverse correlation between substrate size and activity recovery [245]). Then, the dexOx modified enzyme was immobilized on amino activated silica, maintaining a much higher activity compared to that obtained when the enzyme was immobilized on glutaraldehyde-activated supports. This was explained by the increased mobility of the enzyme when immobilized using dexOx; moreover, the modified enzyme was more stable than the free enzyme or the glutaraldehyde-immobilized derivative [245]. Similarly, a protease from Streptomyces 771 was immobilized on dexOx-activated supports, exhibiting reasonable activity recoveries compared to the use of rigid and short spacer arms [246]. In another described example, agarose beads activated with lowly activated dexOx were employed to immobilize rennin (for hydrolyzing casein) and protein A (that must interact with immunoglobulins) [247]. Proteolytic activity of immobilized rennin was reported to be 15-fold higher than the activity of rennin immobilized on an aldehyde support bearing 
shorter spacer arms, while the new immobilized protein A preparations adsorbed, as expected, 2 IgG molecules per immobilized protein A molecule [247].

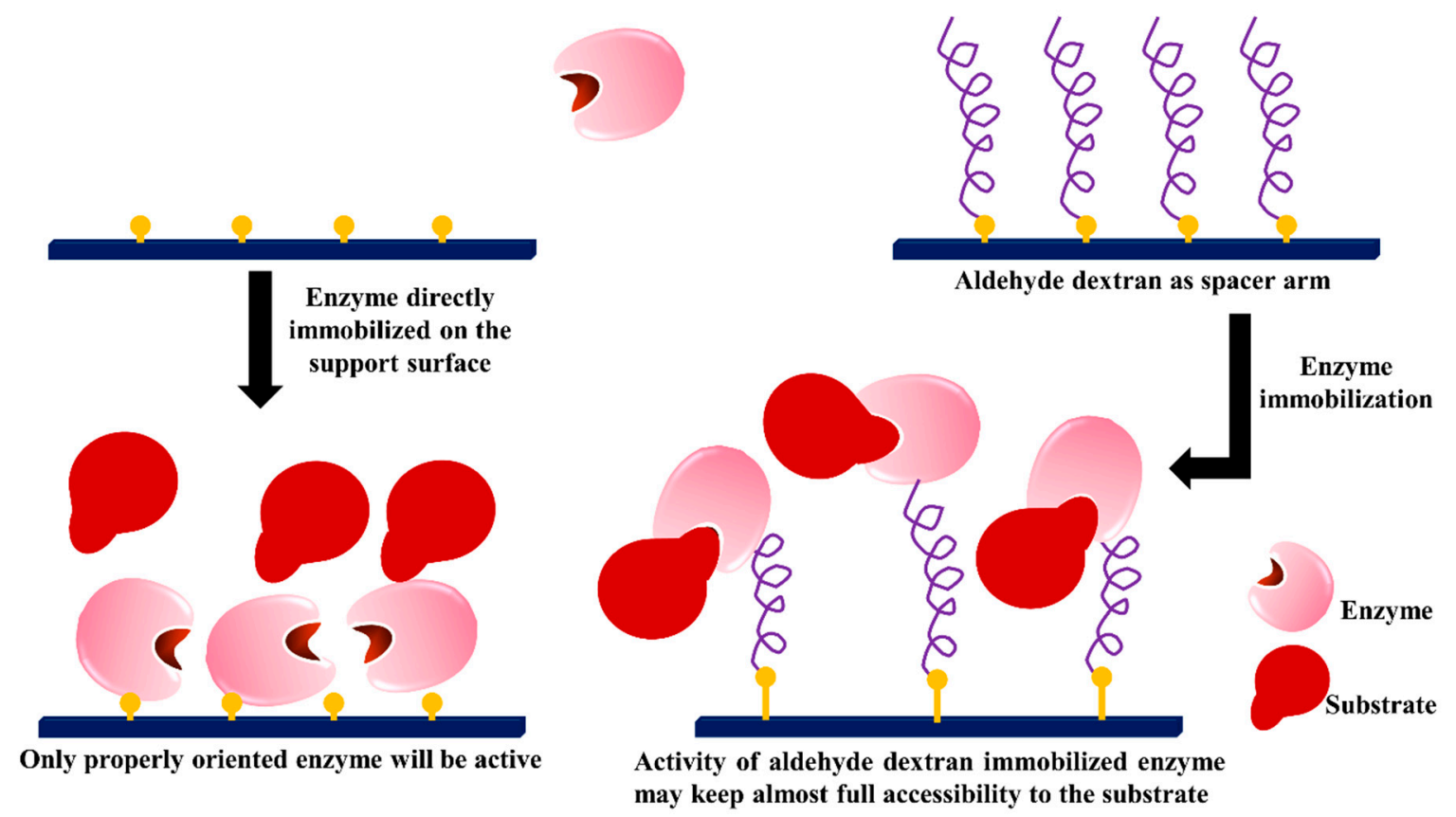

Figure 15. DexOx as spacer arm.

In other cases, the multifunctionality of dextrans is the desired property. For instance, it has enabled us to build molecules like dexOx-aspartic, and to use this polymer as a spacer arm for immobilizing aminated DNA probes. Thus, it was possible to immobilize many aminated DNA probes, keeping an almost full mobility of the probe, at the same time avoiding the unspecific adsorption of DNA fragments (see Section 3.3), so that promoting a remarkable increase in the response rate and detection limit becomes possible (one complementary DNA molecule per milliliter of problem sample [237]).

The high size of dextran is also beneficial in some cases. In fact, many enzyme molecules can be immobilized on one dextran molecule, therefore increasing the loading capacity of a support. For example, $2000 \mathrm{KDa}$ dexOx was used to immobilize multiple copies of alkaline phosphatase, around 27-31 molecules of enzyme were attached per dextran molecule [248]. Afterward, these composites were immobilized in a nylon membrane, reporting a 14-20 fold increase in the chemiluminescence signal when compared to the same amount of enzyme directly adsorbed on a nylon membrane. This biocatalyst was utilized for the high-throughput chemiluminescence detection of biotin-conjugated anti-rabbit antibody, finding a detection limit of 880 attomol per spot on the nylon membrane [248].

\subsection{Generation of Hydrophilic Microenvironments in Immobilized Enzymes}

The modification of immobilized enzymes with dexOx has been proposed as a useful tool to generate a hydrophilic shell surrounding the enzyme molecules. This hydrophilic shell can induce the partition of hydrophobic molecules away from the enzyme environment [34], thus reducing the cause of enzyme inactivation, that is, the concentration of solvent in contact with it, leading to enzyme stabilization in the presence of hydrophobic organic cosolvents.

The first attempt to follow this strategy was described using penicillin $G$ acylase immobilized on glyoxyl agarose [249-251]. The coating of the immobilized enzyme with dexOx produced some disappointing results, because no stabilization was observed after enzyme coating; in fact, stability was even lower in the presence of organic solvents after dexOx enzyme coating [251]. Similarly, coimmobilization of the enzyme with polyethylenimine did not show any positive effect regarding the 
stability of the immobilized penicillin G acylase in organic solvents [251], even though this polymer had been frequently reported to be useful for this purpose [252]. The authors explained these results considering that the enzyme coating with the hydrophilic polymers was not perfect, so that some areas of the protein remained exposed to the organic solvent [251]. Finally, the combination of polyethylenimine coimmobilization with penicillin $\mathrm{G}$ acylase on the glyoxyl-agarose support and the further coating with dexOx led to the generation of a highly hydrophilic nano-environment fully surrounding the immobilized enzyme molecules. This biocatalyst retained $80 \%$ of the activity of the free enzyme and was stabilized 1000-times when incubated in 90\% tetraglyme [251]. The stabilization effect was subsequently enhanced by adding successive layers of the polymers and including sulfate dextran to increase the "saline" effect of the modification $[253,254]$. These biocatalysts, displaying this "hyperstabilization" effect versus the deleterious influence of organic solvents, could be efficiently used in several applications, such as the hydrolysis of penicillin $G$ in the presence of methyl isobutyl ketone (used to extract penicillin $\mathrm{G}$ from the fermentation medium) without a significant decrease in enzyme activity/stability [255], the production of amides using a thermodynamically-controlled synthesis in media containing a high percentage of cosolvent [256], or the resolution of racemic phenylacetamides in the above-mentioned media [257].

Similarly, $\beta$-galactosidases from different sources (Kluyveromyces lactis, Escherichia coli and Aspergillus oryzae) were immobilized on glutaraldehyde-agarose and then modified by reaction with dexOx and finally with polyamine-dextran [258]. This strategy produced a significant stabilization of all immobilized enzymes in organic solvents, while scarcely affecting the kinetic parameters of the immobilized enzymes. These data suggested that the hydrophilic shell appears to behave as an open structure (that permits the entry of the substrates) and produces a "solvent partition effect" that protects the immobilized enzymes from interaction with the hydrophobic organic, as shown in Figure 16.

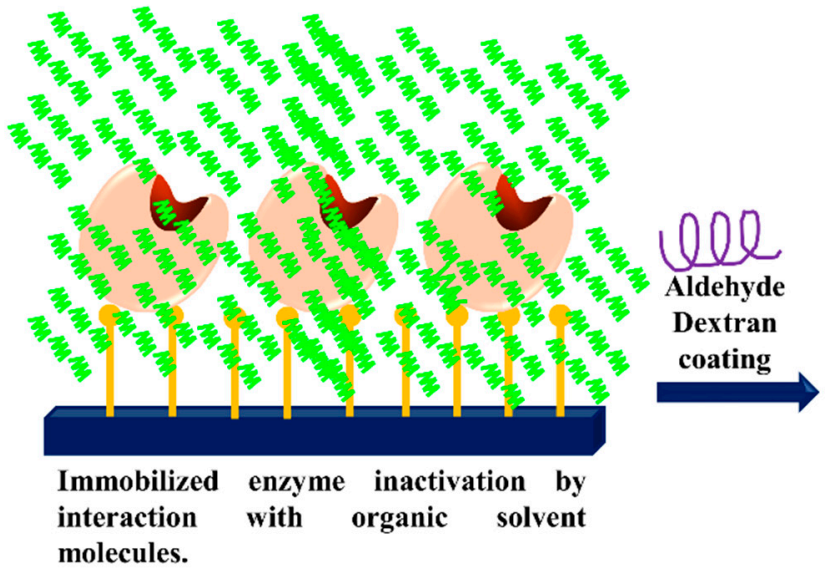

molecules.

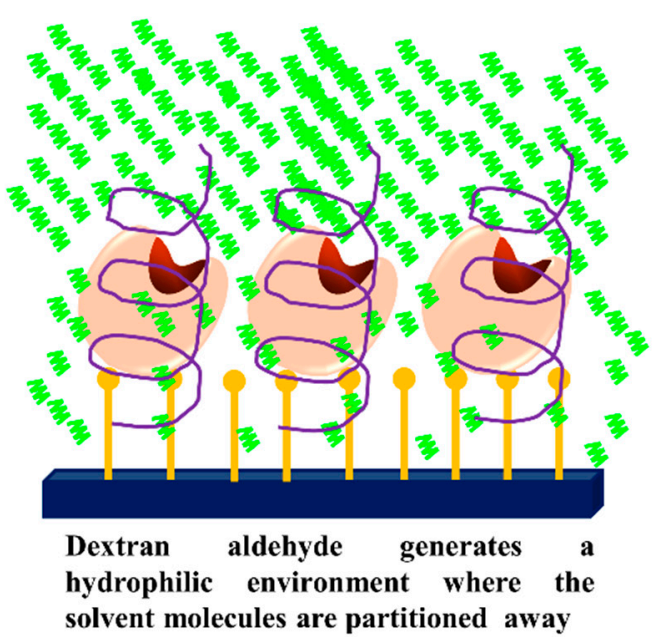

solvent molecules are partitioned away

\section{Organic solvent molecules}

Figure 16. Generation of hydrophilic enzyme nanoenvironments by using dexOx.

Sometimes, modified dextran has been used to generate a hydrophobic pocket surrounding on the enzyme environment, which enables a protection versus hydrophilic agents like hydrogen peroxide [37]. So, modification of D-amino acid oxidase from Rhodotorula gracilis immobilized on glyoxyl-agarose with dexOx bearing hydrophobic groups enabled us to increase the enzyme stability compared to hydrogen peroxide [259].

\subsection{Stabilization of Multimeric Enzymes}

The prevention of the dissociation of multimeric enzymes is very relevant for the stability of this type of enzymes, as in some instances the first step of the inactivation is the subunit 
dissociation [71,260-262], as depicted in Figure 17. This disaggregation will make enzyme stability dependent on enzyme concentration, and would also hamper the use of these biocatalysts in a continuous reactor, as the continuous washing will remove the released enzyme subunits [71]. Moreover, even if the enzyme subunit dissociation is not the first cause for enzyme inactivation, when using an immobilized enzyme, if the subunits become released from the support (even after enzyme inactivation), they will contaminate the reaction medium [71] (Figure 18).
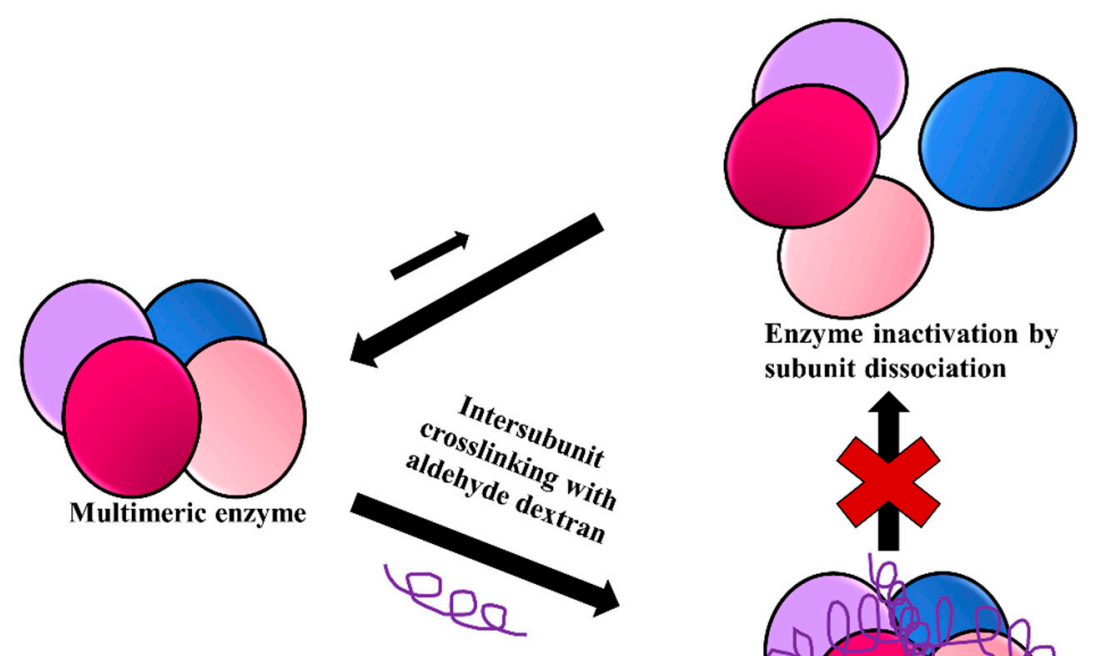

subunit dissociation

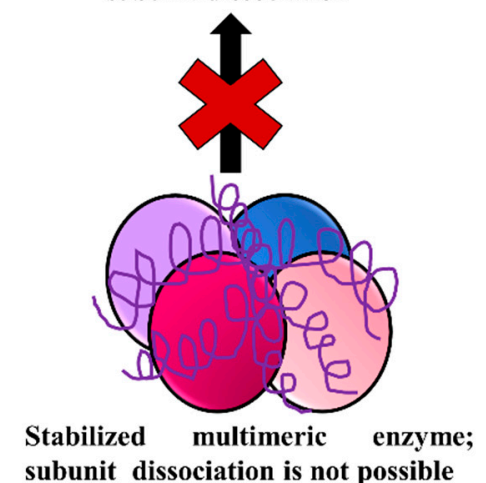

Figure 17. Stabilization of multimeric enzymes by intersubunit crosslinking using dexOx.

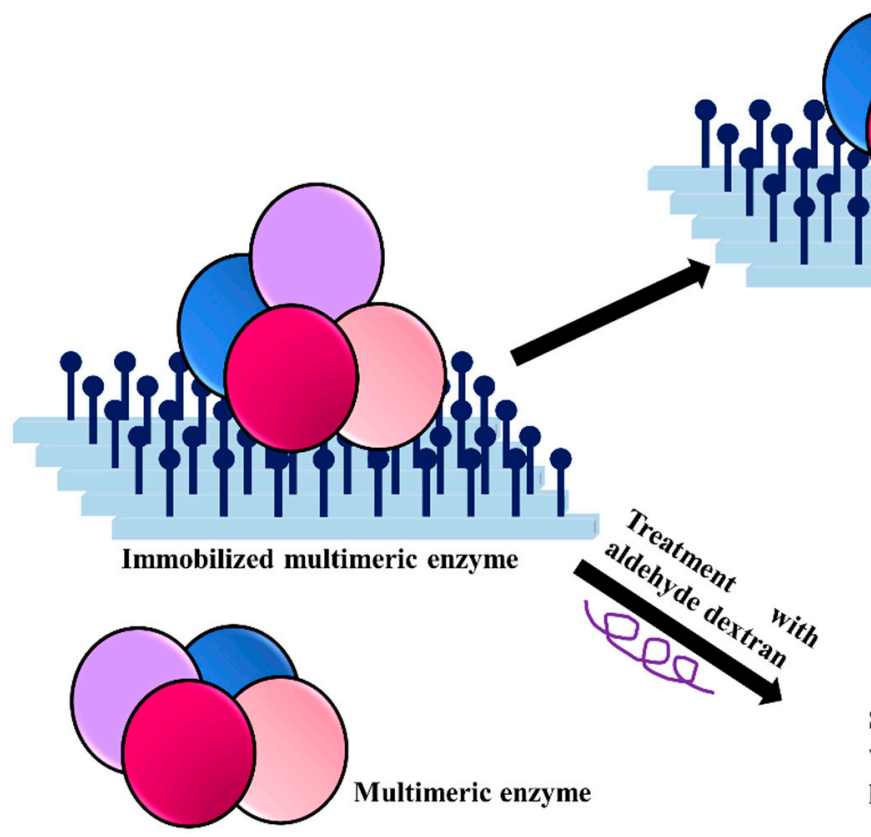

Figure 18. Stabilization of immobilized multimeric enzymes by intersubunit crosslinking using dexOx if some enzyme subunits remain no attached to the support.

This has made the stabilization of the correct assembly of multimeric enzymes an attractive target in biocatalysts design, which has been addressed by many different approaches: molecular genetics (to reinforce the enzyme assembly by improving the ionic network $[263,264]$ or by

Stabilization of multimeric enzyme by crosslinking with aldehyde dextran; subunit dissociation is not possible.

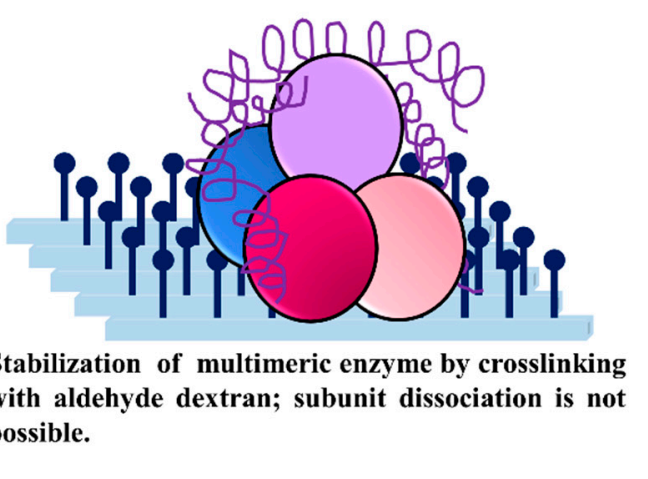


disulfide formation $[265,266])$, immobilization $[267,268]$ or chemical modification $[269,270]$. Although polyethylenimine (PEI) has been used in some instances to stabilize multimeric enzymes $[169,252]$, the reversible nature of this modification has promoted the use of dexOx as a good alternative. However, in some cases the dexOx chemical modification produces detrimental effects on the enzyme activity and the only alternative is the use of PEI [168]. In any case, the reasons for preferring these multifunctional and large molecules to small bifunctional ones, even leading to a lower rigidification degree, are very evident $[69,70]$ :

- The polymer size and the presence of multiple reactive groups make the one-point chemical modification less probable than the desired crosslinking.

- Similarly, also caused by the number and size of reactive groups, it is not necessary that the distance between the chemical groups involved in the crosslinking must fit one specific size.

- The flexibility of dextran allows one single molecule of dextran to react with a large percentage of the enzyme surface.

Remarkably, the inter-subunit crosslinking of multimeric enzymes had been mainly described using immobilized enzymes [71]. This has some advantages; first, as the enzyme is already stabilized, it is more likely that the ulterior chemical modification would cause a smaller effect on the enzyme activity. Secondly, this modification is clearly easier taking advantage of the simplicity associated to solid phase chemistry. Finally, as some of the enzyme subunits will be already attached to the support and stabilized by immobilization, it is only required to attach the non-immobilized enzyme subunits to some of the immobilized ones to prevent enzyme dissociation. Accordingly, by the end of last century, it was clearly shown that the treatment with dexOx of an immobilized crude protein extract permitted the full intermolecular crosslinking of virtually every multimeric enzyme immobilized in an agarose support [271]. Later, the strategy was individualized for specific cases; thus, the tetrameric L-asparaginase from Escherichia coli was immobilized on glutaraldehyde-agarose, observing improved enzyme stability. However, some subunits could be released from the support because they were not actually attached to the support. This was solved by the treatment of the immobilized enzyme with dexOx and opened new scenarios for using this asparaginase preparation [272]. In another research study, the tetrameric $\alpha$-amino acid ester hydrolase from Acetobacter turbidans was immobilized on glyoxyl agarose, but still one enzyme subunit remained unattached to the support [273]. This fact limited the viable reaction conditions for its use as catalysts in the kinetically controlled synthesis of ampicillin. Nevertheless, the treatment of the immobilized biocatalysts with dexOx endorsed the use of this biocatalysts in $40 \%$ methanol and with low concentrations of phosphate ions (anion otherwise needed to stabilize the multimeric structure of the enzyme), so that the final ampicillin yield could be greatly improved (over 90\%) [273].

Catalases are multimeric enzymes frequently used coupled to oxidases in order to reduce the negative impact of the released hydrogen peroxide [37], so that many examples in which the catalase subunits have been crosslinked to improve the biocatalyst stability may be found in literature. For example, Mn-catalase from Thermus thermophilus strains HB8 and HB27 were stabilized by immobilization on glyoxyl agarose [274]. However, a direct correlation between enzyme concentration and stability was still observed, pointing towards the dissociation of some enzyme subunits, so that the modification with partially oxidized dextrans permitted the stabilization of the quaternary structure of these enzymes [274] (Figure 18). Conversely, tetrameric bovine liver catalase was immobilized on glyoxyl agarose, once again enhancing the enzyme stability, but not involving all enzyme subunits. This was solved by dexOx intersubunit crosslinking, as catalase immobilized either on lowly activated supports (where just one subunit was immobilized) or on highly activated supports, (where 2-3 subunits were involved in the immobilization) [275]. In another example, multimeric catalase from Aspergillus niger was covalently immobilized on agarose, increasing the enzyme stability even though some subunits were still not immobilized [276]. The further coating with dexOx avoided this problem, although enzyme concentration/stability dependence was still detected. This permitted 
to find that $\mathrm{Zn}^{2+}$ was also critical for enzyme stability. That way, the stabilization of the multimeric enzyme structure enabled to discover another dissociative process related to the inactivation of this enzyme [276].

Xylanase, $\beta$-xylosidase and $\alpha$-L-arabinofuranosidase from Penicillium janczewskii were immobilized on glyoxyl agarose, and after crosslinking with partially oxidized dexOx, the enzymes stabilities were greatly increased [277]. This strategy originated a combibiocatalyst able to fully hydrolyze wheat arabinoxylans and oat spelt, with xylose yield higher than $40 \%$. Another reported paper described the immobilization of glycerol dehydrogenases from Geobacillus stearothermophilus, Citrobacter braakii and Cellulomonas sp. on different agarose beads, being the results using amine and glyoxyl support the best ones [278]; once again, a further treatment with dexOx stabilized the multimeric structure of the enzyme, also decreasing the inhibition of the enzyme caused by the reaction product (1,3-dihydroxyacetone). Multimeric deoxyribonucleoside kinase from Drosophila melanogaster was immobilized via anionic exchange in an aminated support and after intersubunit cross-linking with dexOx maintained was more than $30 \%$ of the activity [279]. This stabilized biocatalyst was employed for the preparative production of fludarabine monophosphate and arabinosyladenine monophosphate. In another example, the multimeric alcohol oxidases from Hansenula sp, and Pichia pastoris were immobilized on glyoxyl agarose [280]. The stability of the enzymes improved, but still some enzyme subunits were not immobilized on the support, as a consequence some subunit dissociation was found. The problem could be solved by treatment with dexOx, although in this case a serious decrease of enzyme activity was reported.

Thermophilic enzymes are fascinating enzymes, by far more stable than their mesophilic counterparts [281-288]. A reported mechanism of enzyme thermostabilization in these organisms is the production of multimeric enzymes, that increase their global stability. However, also for thermophilic enzymes the subunit dissociation during biocatalysts operation is a problem [68]. That way, prevention of enzyme subunit dissociation as cause of enzyme inactivation or after the enzyme has been inactivated remains as a goal in the design of immobilized biocatalysts involving thermophilic enzymes. For example, a hexameric alpha-galactosidase from Thermus sp. T2 was immobilized on cyanogen bromide-activated agarose (via a single-point linkage), obtaining a biocatalyst displaying a stability similar to that of the free enzyme. This strategy was unable to avoid the release of enzyme subunits from the biocatalyst [289]. The further intersubunit cross-linking with dexOx of these biocatalysts increased the enzyme stability and prevented the enzyme subunit release. Moreover, a thermostable $\beta$-galactosidase from Thermus sp. strain T2 was immobilized on heterofunctional epoxy supports [290]. The enzyme immobilized on Sepabeads-epoxy-boronic was found to be the most stable, but still one enzyme subunit was not-attached to the support; this was solved by dexOx coating of the biocatalyst, avoiding any enzyme subunit release (Figure 18), although reducing the enzyme stability, because the inactivation of this enzyme is not initialized by the subunit dissociation and the polymer was less rigid than the enzyme.

Occasionally, PEI and dexOx have been compared to check their ability to stabilize oligomeric enzymes, in some cases reporting the best results by using just one of them, while in other instances the combination of both polymers produced the highest biocatalyst stabilization. For example, this is the case of a hexameric glutamate dehydrogenase from Escherichia coli, an enzyme whose stability presented a very significant dependence on the protein concentration [168]. In this particular case, the crosslinking with dexOx caused the enzyme inactivation, leaving the treatment with polyethylenimine as the only way to stabilize the quaternary structure of the enzyme. In another example, the tetrameric $\beta$-xylosidase from Selenomonas ruminantium was immobilized on glyoxyl agarose beads, with scarce effect on enzyme stability due to the possibility of subunit release [291]. It was treated with polyethylenimine or dexOx. The PEI treatment produced the most stable enzyme preparation. In another example, the homotetrameric sucrose synthase from Acidithiobacillus was immobilized-stabilized on differently activated agarose beads, leading to the highest stability when using glyoxyl agarose [292]. However, as some subunits were not attached to the support, the biocatalyst was treated with dexOx or/and 
polyethyleneimine, observing that the combined use of both polymers fully stabilized the quaternary structure of the enzyme.

In other instances, the enzyme was adsorbed on PEI-coated supports. For example, pectinase was immobilized on polyethyleneimine-coated acrylate copolymer DILBEAD-VWR and hereinafter used for clarification of apple juice [293]. In this particular case, only the treatment with dexOx permitted the stabilization of the enzyme, allowing the reuse of the support after enzyme inactivation by washing with $1 \mathrm{~N} \mathrm{HCl}$ to eliminate from the inactivated biocatalyst every molecule of inactivated enzyme. In another example, multimeric nucleoside 2'-deoxyribosyltransferase from Bacillus psychrosaccharolyticus CECT 4074 was immobilized onto several supports, being the best results those obtained by adsorbing the enzyme on PEI-agarose [294]. Further crosslinking with dexOx avoided subunit dissociation and greatly improved the enzyme function. Conversely, recombinant multimeric uridine and purine nucleoside phosphorylases from Bacillus subtilis were immobilized onto polyethyleneimine Sepabeads [295]. As these preparations showed a dependence of their stability on the enzyme concentration, they were crosslinked with dexOx. This treatment avoided the risk of enzyme dissociation (Figure 18) and permitted that the biocatalysts were successfully utilized in the production of $2^{\prime}$-deoxyguanosine via an enzymatic transglycosylation in an aqueous solution between $2^{\prime}$-deoxyuridine and guanine $[295,296]$.

\subsection{Enzyme Coimmobilization Using DexOx as Glue}

Enzyme coimmobilization presents some kinetic advantages in a cascade process [297-300]. However, it also involves some drawbacks, such as the decrease in the relative loading capacity of the support for each enzyme, the dependence of the overall stability of the whole biocatalyst on the particular stability of the less stable component of this combined catalyst, and the need to use the same immobilization technique for all enzymes [167]. Therefore, some new coimmobilization strategies are being studied [301-304]; one of the solutions proposed for the first above-mentioned problem involves the use of dexOx (Figure 19.) In fact, dexOx was used to coimmobilize tetrameric $\beta$-D-galactosidase from Kluyveromyces lactis [305,306] and the lipase from Thermomyces lanuginosus previously immobilized on hydrophobic magnetic nanoparticles [307]; after lipase immobilization, the enzyme was chemically aminated and thereafter, the lactase was coimmobilized via ion exchange on the aminated enzyme. A final treatment of the coimmobilized enzymes with dexOx, promoting the intermolecular crosslinking, avoided any lactase release [307] and increased the stability of the galactosidase, very likely due to the crosslinking of the monomeric subunits [71].
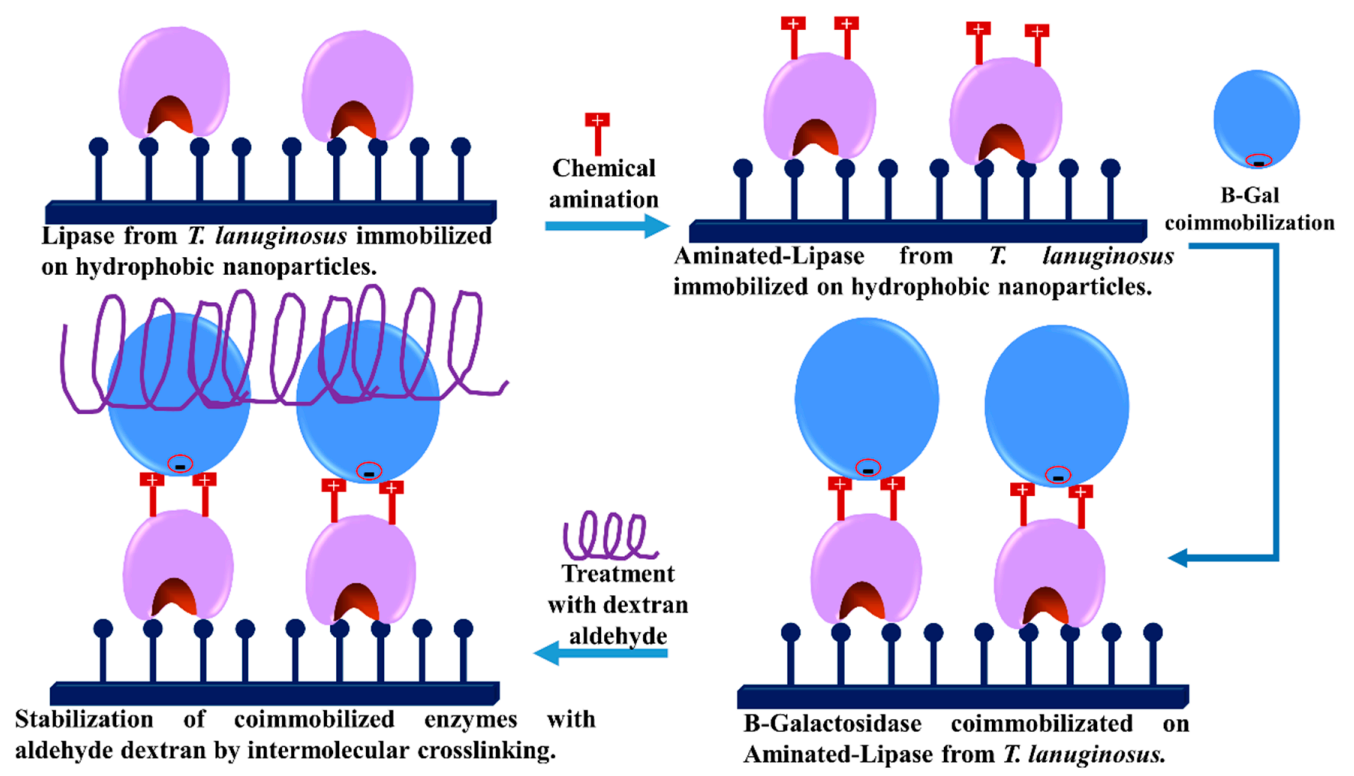

Figure 19. Use of dexOx to stabilize coimmobilized enzymes. 


\section{8. -Use of dexOx for Intermolecular Crosslinking of Immobilized Enzyme Molecules}

Physical adsorption of proteins on activated supports is a very useful and simple method to immobilize enzymes $[167,235]$; however, as the surfaces will never be physically inert [167], this could be deleterious for the stability of the immobilized enzyme [308], as new enzyme-support interactions may be produced during storage or operation, leading to enzyme inactivation [309,310]. Furthermore, each individual enzyme-support linkage is too weak to increase the enzyme rigidity [167]. In fact, only multimeric enzymes should be stabilized upon immobilization on these supports, provided that all enzyme subunits are involved in the immobilization, preventing the subunit dissociation [71]. Nevertheless, there is a particular situation where enzymes become stabilized upon physical immobilization: the immobilization of lipases on hydrophobic supports via interfacial activation, allowing the immobilization, stabilization, purification and hyperactivation of the lipases in just one step [157]. Anyhow, the inherent drawback of this immobilization protocol is caused by the enzyme release from the carrier to the medium, under certain conditions and in the presence of detergent-like molecules [311], reducing the range of reaction conditions where these biocatalysts may be used (Figure 20). This has been solved using different heterofunctional supports, bearing different groups on the support surface with different functions for a better control of the immobilization procedure [312-315], performing the physical intermolecular crosslinking of the immobilized enzyme using polyethylenimine [316-318] or using dexOx as chemical crosslinking reagent [319] (Figure 21). The large size and number of functional groups of dexOx allow multi-intermolecular enzyme crosslinking, thus preventing enzyme release.

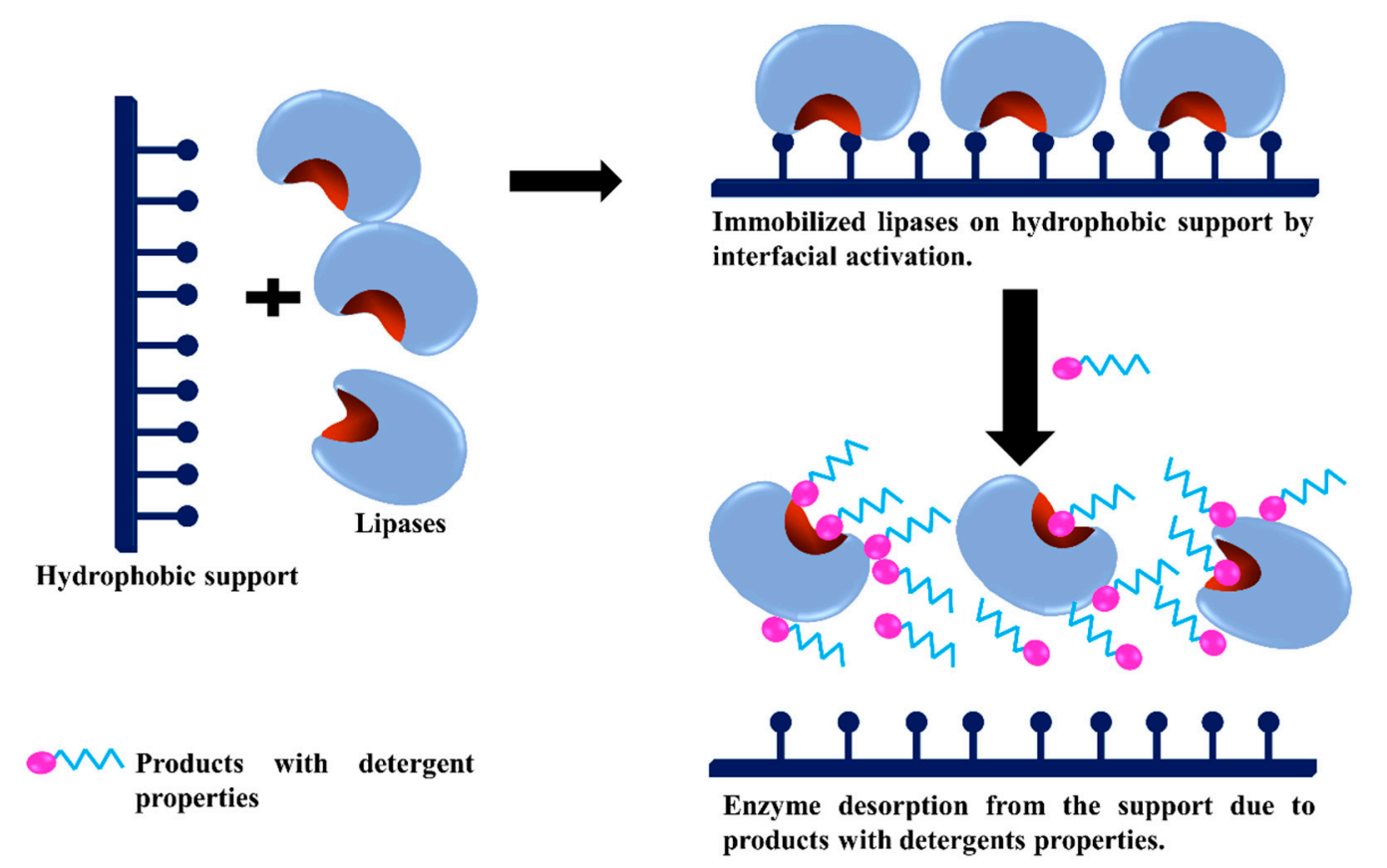

Figure 20. Release of lipases from hydrophobic supports in the presence of detergent like substrates or product (mono or diglycerides, free fatty acids, etc). 


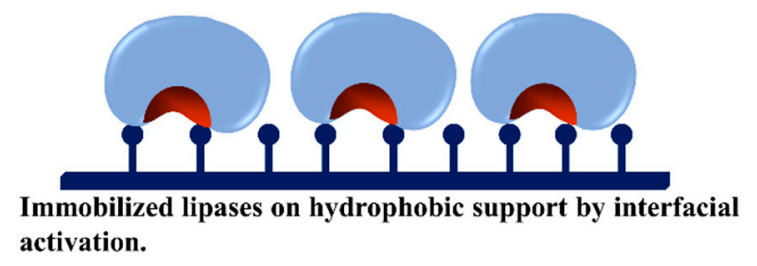

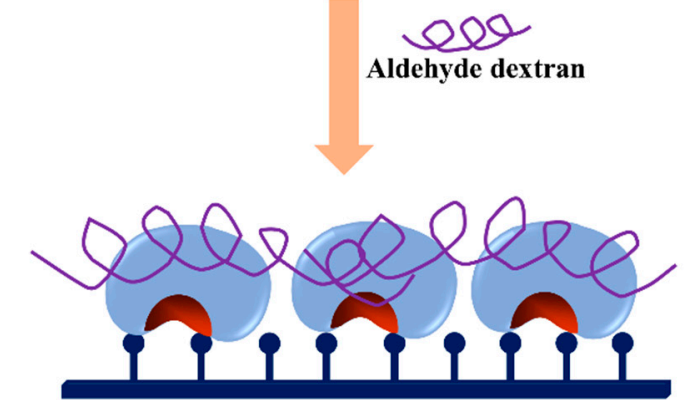

Immobilized lipases crosslinked with aldehyde dextran to prevent enzyme desorption .

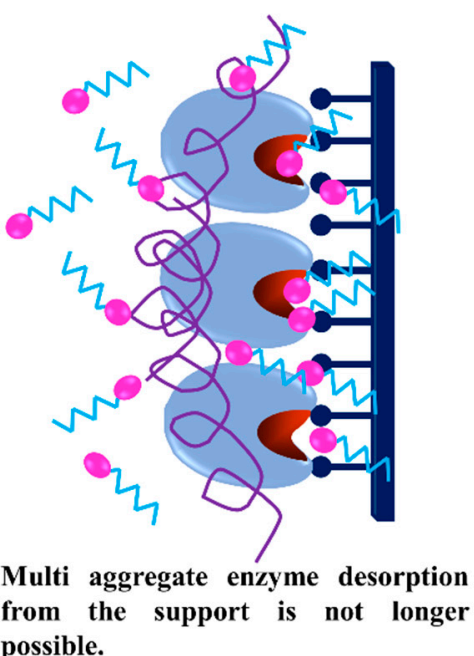

from thessible.

$M$ Products with detergent properties

Figure 21. Intermolecular crosslinking of lipases immobilized on hydrophobic supports to prevent their release during operation.

In a representative example, the hydrolysis of fish oils by the lipase from Rhizomucor miehei immobilized on hydrophobic supports and crosslinked with dexOx could be performed in a reaction medium containing high concentrations (50\%) of a water-miscible organic solvent (2-propanol); under these conditions, the hydrolysis increased the biocatalyst selectivity towards the release of eicosapentaenoic acid versus docosahexaenoic acid (from $4: 1$ to 22:1) [319]. In another paper, the lipase from Candida cylindracea immobilized on hydrophobic supports was treated with dexOx and dextran sulphate and used to generate a biocatalyst able to hydrolyze fish oil in a biphasic system formed by $50 \%$ of $1 / 4$ oil/hexane and $50 \%$ of polyethylene glycol/phosphate buffer (4/6) [320]. In this case, both stability and activity were higher using dextran sulphate, this could be because of the higher hydrophilicity of the enzymatic shell.

Another fully different use of dexOx is in the area of proteomics. It has been shown that a rapid crosslinking of a protein solution (e.g., using a high concentration of dexOx) rapidly coats the proteins surfaces and avoids any crosslinking between two non-associated protein molecules [321]. On the other hand, it has been shown that only large proteins will become adsorbed on lowly aminated supports, as ion exchange requires a multi-interaction between the enzyme and the support [322] (Figure 22). Having these two concepts in mind, a strategy was developed in order to get associated enzymes, even when the percentage of oligomeric proteins was minimal, based on the selective adsorption of the protein complexes on tailor-made anionic exchanger supports (to shift the association equilibrium to the oligomeric form) and a further crosslinking with aldehyde dextran (to stabilize the complex and, consequently, to make possible the release of the complex from the support in an associated form) [226,323] (Figure 23). 


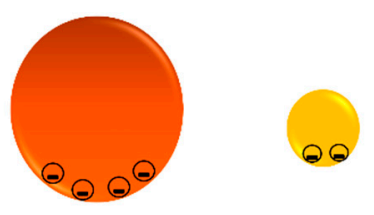

9999999999999

Highly activated anion exchanger

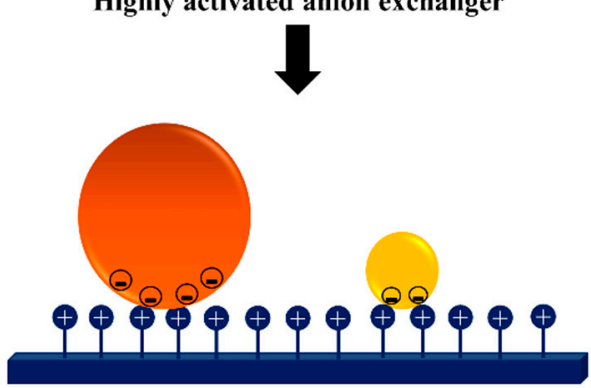

Small and large proteins can become adsorbed

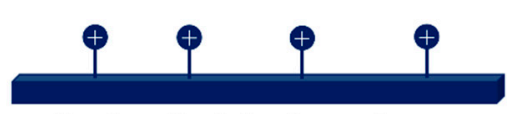

Lowly activated anion exchanger

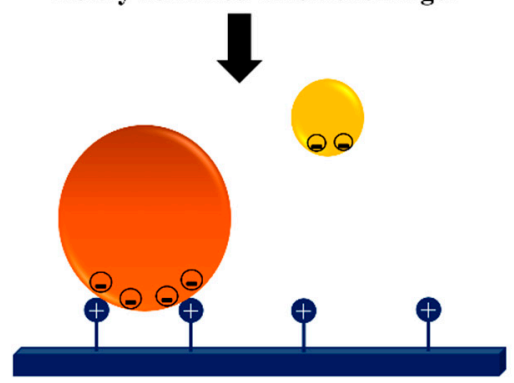

Only large proteins can become adsorbed

Figure 22. Selective adsorption of large proteins in lowly activated ion exchangers.

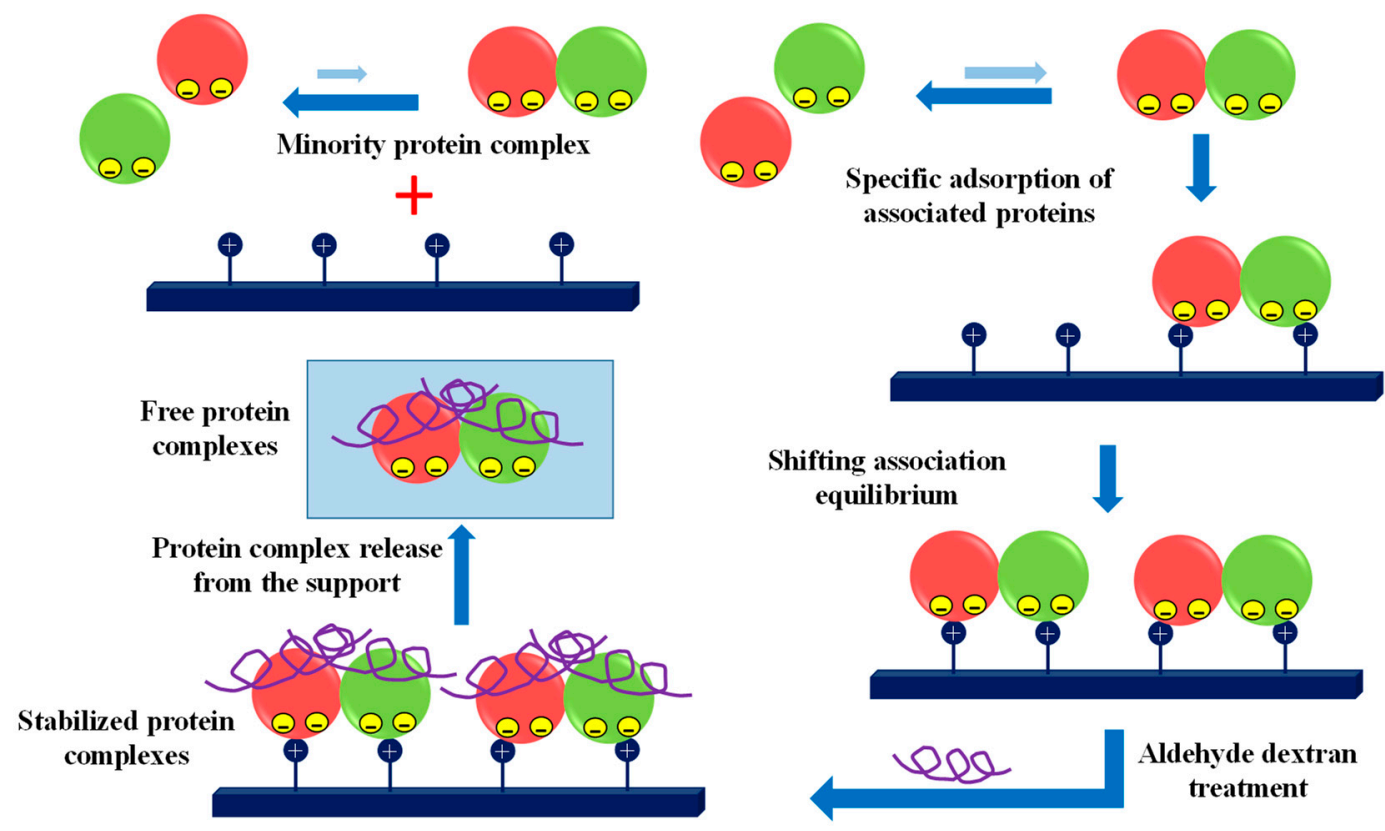

Figure 23. Shifting association equilibrium of weak enzyme complexes using lowly activated supports and final crosslinking of the immobilized complexes with dexOx.

Later, the same group were able to produce protein aggregates of the desired size using bovine serum albumin, a protein with a great tendency to aggregate [324-327]; just decreasing the activation of the support, it was possible to get larger aggregates, being the dexOx crosslinking essential to maintain these aggregates after their release from the support [328] (Figure 24). 


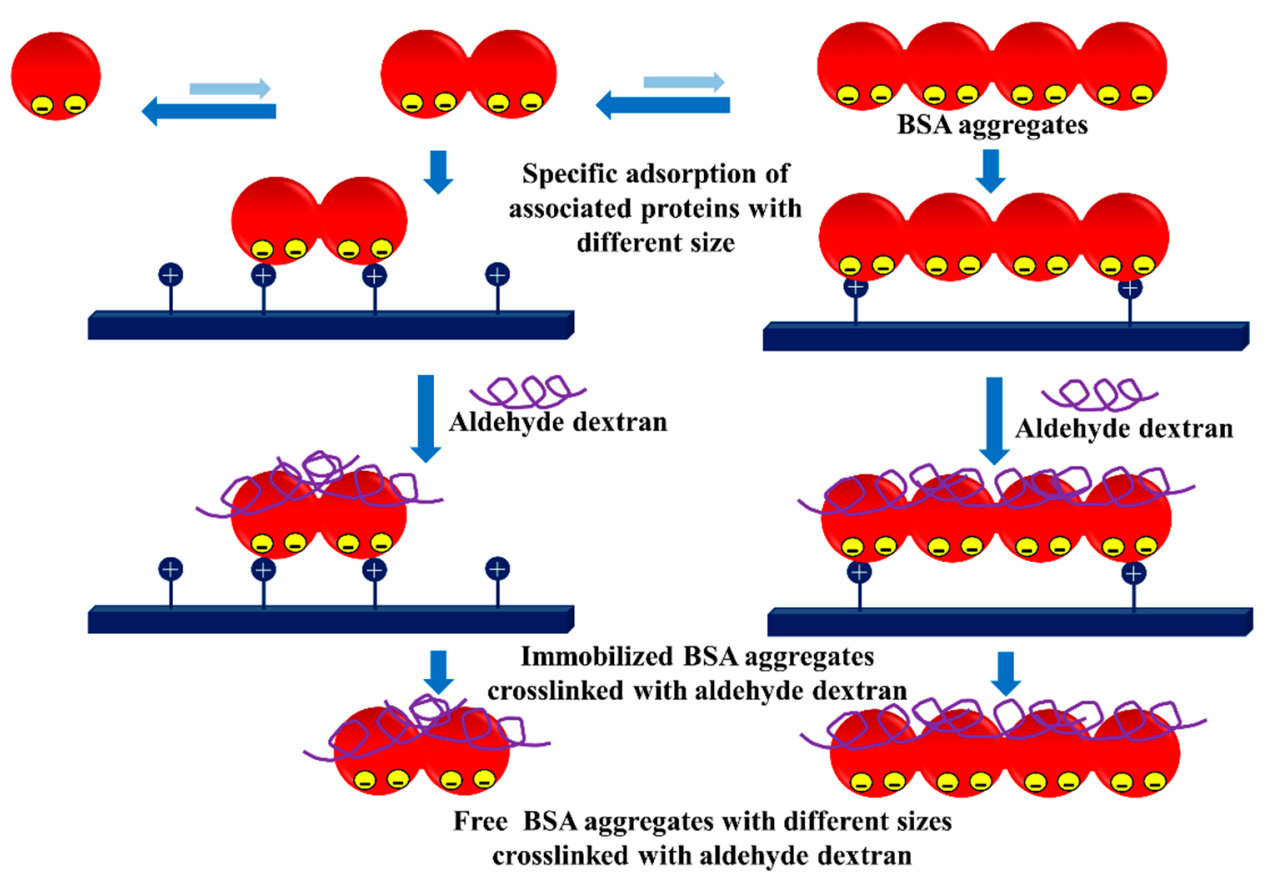

Figure 24. Controlling the aggregation of BSA by controlling the activation of ion exchangers and final crosslink of the BSA complexes with dexOx.

\section{Conclusions}

As shown throughout this article, dexOx is a very useful reactive polysaccharide within the field of biocatalysis. Its easy use, as well as the multiple applications that it presents, make dexOx an extremely valuable biomolecule to solve some critical situations in biosensor and biocatalysts design, including not only enzyme immobilization but also purification. The key for its applicability is the mobility and inertness (after chemical reduction) inherent to dexOx, while this flexibility helps the enzyme stabilization via rigidification complex. Thus, its application in the design of matrices for affinity chromatography and production of biosensors is based on these features. The huge amount of reactive groups inside dexOx and its large size make it very convenient for stabilization of multimeric enzymes via subunit crosslinking, while also making it ideal as a spacer arm for enzymes acting over large substrates. Multiple examples of very useful applications will surely be published in the coming years, exploiting some of these features. It has been our purpose to summarize some of these applications for many different enzymes and proteins (antibodies, hydrolases, oxidoreductases, etc.) in order to provide a comprehensive compilation of dexOx expediency in the chemical engineering of biocatalysts.

Author Contributions: A.R.A. and R.F.-L.: conceptualization, writing-original draft preparation, writing-review and editing, supervision, V.G.T.-P.: writing—original draft preparation, writing—review and editing, C.O., Á.B.-M., N.R., N.A., I.A. and C.C.: writing-review and editing.

Funding: This research was funded by the Ministry of Science, Innovation and Universities from Spanish Government (project numbers MAT2015-65184-C2-1_R and CTQ2017-86170-R) and Colciencias (Colombia) (project number FP 44842-076-2016).

Acknowledgments: Tacias-Pascacio thanks CONACyT Mexico for her Postdoctoral fellowship (No. 005126).

Conflicts of Interest: The authors declare no conflict of interest.

\section{References}

1. Hoyos, P.; Hernáiz, M.J.; Alcántara, A.R. Biocatalyzed production of fine chemicals. In Reference Module in Life Sciences; Elsevier: Amsterdam, The Netherlands, 2017. [CrossRef]

2. Sheldon, R.A.; Pereira, P.C. Biocatalysis engineering: The big picture. Chem. Soc. Rev. 2017, 46, $2678-2691$. [CrossRef] 
3. Alcántara, A.R. Biotransformations in drug synthesis: A green and powerful tool for medicinal chemistry. J. Med. Chem. Drug Des. 2018, 1, 1-7.

4. Devine, P.N.; Howard, R.M.; Kumar, R.; Thompson, M.P.; Truppo, M.D.; Turner, N.J. Extending the application of biocatalysis to meet the challenges of drug development. Nat. Rev. Chem. 2018, 2, 409-421. [CrossRef]

5. Hoyos, P.; Pace, V.; Alcántara, A.R. Chiral building blocks for drugs synthesis via biotransformations. In Asymmetric Synthesis of Drugs and Natural Products; Nag, A., Ed.; CRC Press: Boca Raton, FL, USA, 2018; pp. 346-448.

6. Patel, R.N. Biocatalysis for synthesis of pharmaceuticals. Bioorg. Med. Chem. 2018, 26, 1252-1274. [CrossRef] [PubMed]

7. Rosenthal, K.; Lütz, S. Recent developments and challenges of biocatalytic processes in the pharmaceutical industry. Curr. Opin. Green Sustain. Chem. 2018, 11, 58-64. [CrossRef]

8. Sheldon, R.A.; Brady, D. The limits to biocatalysis: Pushing the envelope. Chem. Comm. 2018, 54, 6088-6104. [CrossRef] [PubMed]

9. Sheldon, R.A.; Woodley, J.M. Role of Biocatalysis in Sustainable Chemistry. Chem. Rev. 2018, 118, 801-838. [CrossRef]

10. Sun, H.; Zhang, H.; Ang, E.L.; Zhao, H. Biocatalysis for the synthesis of pharmaceuticals and pharmaceutical intermediates. Bioorg. Med. Chem. 2018, 26, 1275-1284. [CrossRef]

11. Turner, N.J.; Kumar, R. Editorial overview: Biocatalysis and biotransformation: The golden age of biocatalysis. Curr. Opin. Chem. Biol. 2018, 43, A1-A3. [CrossRef]

12. Adams, J.P.; Brown, M.J.B.; Diaz-Rodriguez, A.; Lloyd, R.C.; Roiban, G.D. Biocatalysis: A Pharma Perspective. Adv. Synth. Catal. 2019, in press. [CrossRef]

13. Foley, A.M.; Maguire, A.R. The impact of recent developments in technologies which enable the increased use of biocatalysts. Eur. J. Org. Chem. 2019, in press. [CrossRef]

14. Sheldon, R.A.; Brady, D. Broadening the scope of biocatalysis in sustainable organic synthesis. ChemSusChem 2019, in press. [CrossRef] [PubMed]

15. Woodley, J.M. Accelerating the implementation of biocatalysis in industry. Appl. Microbiol. Biotechnol. 2019, in press. [CrossRef] [PubMed]

16. Schoemaker, H.E.; Mink, D.; Wubbolts, M.G. Dispelling the myths-Biocatalysis in industrial synthesis. Science 2003, 299, 1694-1697. [CrossRef] [PubMed]

17. Robles-Medina, A.; Gonzalez-Moreno, P.A.; Esteban-Cerdan, L.; Molina-Grima, E. Biocatalysis: Towards ever greener biodiesel production. Biotechnol. Adv. 2009, 27, 398-408. [CrossRef] [PubMed]

18. Teixeira, C.B.; Madeira, J.V.; Macedo, G.A. Biocatalysis combined with physical technologies for development of a green biodiesel process. Renew. Sust. Energ. Rev. 2014, 33, 333-343. [CrossRef]

19. Budzaki, S.; Miljic, G.; Tisma, M.; Sundaram, S.; Hessel, V. Is there a future for enzymatic biodiesel industrial production in microreactors? Appl. Energy 2017, 201, 124-134. [CrossRef]

20. Amini, Z.; Ilham, Z.; Ong, H.C.; Mazaheri, H.; Chen, W.H. State of the art and prospective of lipase-catalyzed transesterification reaction for biodiesel production. Energy Conv. Manag. 2017, 141, 339-353. [CrossRef]

21. Tacias-Pascacio, V.G.; Torrestiana-Sanchez, B.; Dal Magro, L.; Virgen-Ortiz, J.J.; Suarez-Ruiz, F.J.; Rodrigues, R.C.; Fernandez-Lafuente, R. Comparison of acid, basic and enzymatic catalysis on the production of biodiesel after RSM optimization. Renew. Energy 2019, 135, 1-9. [CrossRef]

22. Oort, M.V.; Whitehurst, R.J. Enzymes in Food Technology, 2th ed.; Wiley-Blackwell: West Sussex, UK, 2010.

23. Pandey, A.; Du, G.; Sanromán, M.A.N.; Soccol, C.R.; Dussap, C.-G. Current Developments in Biotechnology and Bioengineering: Food and Beverages Industry; Elsevier Science: Amsterdam, The Netherlands, 2016.

24. Kuddus, M.; Kahali; Kuddus. Enzymes in Food Technology, 1st ed.; Springer: Singapore, 2018.

25. Raveendran, S.; Parameswaran, B.; Ummalyma, S.B.; Abraham, A.; Mathew, A.K.; Madhavan, A.; Rebello, S.; Pandey, A. Applications of microbial enzymes in food industry. Food Technol. Biotechnol. 2018, 56, 16-30. [CrossRef]

26. Nguyen, H.H.; Lee, S.H.; Lee, U.J.; Fermin, C.D.; Kim, M. Immobilized enzymes in biosensor applications. Materials 2019, 12, 121. [CrossRef] [PubMed]

27. Monteiro, T.; Almeida, M.G. Electrochemical enzyme biosensors revisited: Old solutions for new problems. Crit. Rev. Anal. Chem. 2019, 49, 44-66. [CrossRef] [PubMed] 
28. Gahlaut, A.; Hooda, V.; Gothwal, A.; Hooda, V. Enzyme-based ultrasensitive electrochemical biosensors for rapid assessment of nitrite toxicity: Recent advances and perspectives. Crit. Rev. Anal. Chem. 2019, 49, $32-43$. [CrossRef] [PubMed]

29. Campaña, A.L.; Florez, S.L.; Noguera, M.J.; Fuentes, O.P.; Puentes, P.R.; Cruz, J.C.; Osma, J.F. Enzyme-based electrochemical biosensors for microfluidic platforms to detect pharmaceutical residues in wastewater. Biosensors 2019, 9, 41. [CrossRef] [PubMed]

30. Husain, Q. Carbon nanotubes mediated immobilized glucose oxidase biosensors as an effective and sensitive analytical tool. Biointerface Res. Appl. Chem. 2018, 8, 3060-3074.

31. Luong, J.H.T.; Glennon, J.D.; Gedanken, A.; Vashist, S.K. Achievement and assessment of direct electron transfer of glucose oxidase in electrochemical biosensing using carbon nanotubes, graphene, and their nanocomposites. Microchim. Acta 2017, 184, 369-388. [CrossRef]

32. Cormode, D.P.; Gao, L.Z.; Koo, H. Emerging biomedical applications of enzyme-like catalytic nanomaterials. Trends Biotechnol. 2018, 36, 15-29. [CrossRef] [PubMed]

33. Bakunina, I.Y.; Balabanova, L.A.; Pennacchio, A.; Trincone, A. Hooked on alpha-D-galactosidases: From biomedicine to enzymatic synthesis. Crit. Rev. Biotechnol. 2016, 36, 233-245. [CrossRef] [PubMed]

34. Iyer, P.V.; Ananthanarayan, L. Enzyme stability and stabilization-Aqueous and non-aqueous environment. Process Biochem. 2008, 43, 1019-1032. [CrossRef]

35. Suplatov, D.; Voevodin, V.; Svedas, V. Robust enzyme design: Bioinformatic tools for improved protein stability. Biotechnol. J. 2015, 10, 344-355. [CrossRef] [PubMed]

36. Reyes-De-Corcuera, J.I.; Olstad, H.E.; Garcia-Torres, R. Stability and stabilization of enzyme biosensors: The key to successful application and commercialization. In Annual Review of Food Science and Technology; Doyle, M.P., Klaenhammer, T.R., Eds.; Annual Reviews: Palo Alto, CA, USA, 2018; Volume 9, pp. $293-322$.

37. Hernandez, K.; Berenguer-Murcia, A.; Rodrigues, R.C.; Fernandez-Lafuente, R. Hydrogen peroxide in biocatalysis. A dangerous liaison. Curr. Org. Chem. 2012, 16, 2652-2672. [CrossRef]

38. Rocchitta, G.; Spanu, A.; Babudieri, S.; Latte, G.; Madeddu, G.; Galleri, G.; Nuvoli, S.; Bagella, P.; Demartis, M.I.; Fiore, V.; et al. Enzyme biosensors for biomedical applications: Strategies for safeguarding analytical performances in biological fluids. Sensors 2016, 16, 780. [CrossRef] [PubMed]

39. Deng, S.; Fu, A.L.; Junaid, M.; Wang, Y.; Yin, Q.; Fu, C.; Liu, L.; Su, D.S.; Bian, W.P.; Pei, D.S. Nitrogen-doped graphene quantum dots (N-GQDs) perturb redox-sensitive system via the selective inhibition of antioxidant enzyme activities in zebrafish. Biomaterials 2019, 206, 61-72. [CrossRef] [PubMed]

40. Hdiouech, S.; Bruna, F.; Batisson, I.; Besse-Hoggan, P.; Prevot, V.; Mousty, C. Amperometric detection of the herbicide mesotrione based on competitive reactions at nitroreductase@layered double hydroxide bioelectrode. J. Electroanal. Chem. 2019, 835, 324-328. [CrossRef]

41. Kuwahara, T.; Ogawa, K.; Sumita, D.; Kondo, M.; Shimomura, M. Amperometric glucose sensing with polyaniline/poly(acrylic acid) composite film bearing glucose oxidase and catalase based on competitive oxygen consumption reactions. J. Electroanal. Chem. 2018, 811, 62-67. [CrossRef]

42. Daems, D.; Lu, J.; Delport, F.; Marien, N.; Orbie, L.; Aernouts, B.; Adriaens, I.; Huybrechts, T.; Saeys, W.; Spasic, D.; et al. Competitive inhibition assay for the detection of progesterone in dairy milk using a fiber optic SPR biosensor. Anal. Chim. Acta 2017, 950, 1-6. [CrossRef]

43. Hopkins, S.P.; Pant, J.; Goudie, M.J.; Schmiedt, C.; Handa, H. Achieving long-term biocompatible silicone via covalently immobilized S-nitroso-N-acetylpenicillamine (SNAP) that exhibits 4 months of sustained nitric oxide release. ACS Appl. Mater. Interfaces 2018, 10, 27316-27325. [CrossRef] [PubMed]

44. Grano, V.; Diano, N.; Portaccio, M.; Bencivenga, U.; De Maio, A.; De Santo, N.; Perna, A.; Salamino, F.; Mita, D.G. The alpha (1)-antitrypsin/elastase complex as an experimental model for hemodialysis in acute catabolic renal failure, extracorporeal blood circulation and cardiocirculatory bypass. Int. J. Artif. Organs 2002, 25, 297-305. [CrossRef] [PubMed]

45. Grovender, E.A.; Cooney, C.L.; Langer, R.S.; Ameer, G.A. Modeling of the mixing behavior of the novel fluidized extracorporeal immunoadsorber. Chem. Eng. Sci. 2001, 56, 5437-5441. [CrossRef]

46. Ameer, G.A.; Harmon, W.; Sasisekharan, R.; Langer, R. Investigation of a whole blood fluidized bed Taylor-Couette flow device for enzymatic heparin neutralization. Biotechnol. Bioeng. 1999, 62, 602-608. [CrossRef]

47. Sheldon, R.A.; van Pelt, S. Enzyme immobilisation in biocatalysis: Why, what and how. Chem. Soc. Rev. 2013, 42, 6223-6235. [CrossRef] [PubMed] 
48. Rodrigues, R.C.; Ortiz, C.; Berenguer-Murcia, A.; Torres, R.; Fernandez-Lafuente, R. Modifying enzyme activity and selectivity by immobilization. Chem. Soc. Rev. 2013, 42, 6290-6307. [CrossRef] [PubMed]

49. Singh, R.K.; Tiwari, M.K.; Singh, R.; Lee, J.K. From protein engineering to immobilization: Promising strategies for the upgrade of industrial enzymes. Int. J. Mol. Sci. 2013, 14, 1232-1277. [CrossRef] [PubMed]

50. Barbosa, O.; Ortiz, C.; Berenguer-Murcia, A.; Torres, R.; Rodrigues, R.C.; Fernandez-Lafuente, R. Strategies for the one-step immobilization-purification of enzymes as industrial biocatalysts. Biotechnol. Adv. 2015, 33, 435-456. [CrossRef] [PubMed]

51. Bezerra, C.S.; Lemos, C.; de Sousa, M.; Goncalves, L.R.B. Enzyme immobilization onto renewable polymeric matrixes: Past, present, and future trends. J. Appl. Polym. Sci. 2015, 132, 15. [CrossRef]

52. Eş, I.; Vieira, J.D.G.; Amaral, A.C. Principles, techniques, and applications of biocatalyst immobilization for industrial application. Appl. Microbiol. Biotechnol. 2015, 99, 2065-2082. [CrossRef] [PubMed]

53. Gutarra, M.L.E.; Miranda, L.S.M.; de Souza, R.O.M.A. Chapter 4-Enzyme Immobilization for Organic Synthesis A2-Goswami, Animesh. In Organic Synthesis Using Biocatalysis; Stewart, J.D., Ed.; Academic Press; Elsevier: Amsterdam, The Netherlands, 2016; pp. 99-126. [CrossRef]

54. Schmidt-Dannert, S.; Zhang, G.Q.; Johnston, T.; Quin, M.B.; Schmidt-Dannert, C. Building a toolbox of protein scaffolds for future immobilization of biocatalysts. Appl. Microbiol. Biotechnol. 2018, 102, 8373-8388. [CrossRef] [PubMed]

55. DiCosimo, R.; McAuliffe, J.; Poulose, A.J.; Bohlmann, G. Industrial use of immobilized enzymes. Chem. Soc. Rev. 2013, 42, 6437-6474. [CrossRef]

56. Cantone, S.; Ferrario, V.; Corici, L.; Ebert, C.; Fattor, D.; Spizzo, P.; Gardossi, L. Efficient immobilisation of industrial biocatalysts: Criteria and constraints for the selection of organic polymeric carriers and immobilisation methods. Chem. Soc. Rev. 2013, 42, 6262-6276. [CrossRef]

57. Almeida, O.G.G.; De Martinis, E.C.P. Bioinformatics tools to assess metagenomic data for applied microbiology. Appl. Microbiol. Biotechnol. 2019, 103, 69-82. [CrossRef]

58. Ngara, T.R.; Zhang, H.J. Recent Advances in Function-based Metagenomic Screening. Genom. Proteom. Bioinform. 2019, 16, 405-415. [CrossRef] [PubMed]

59. Bilal, T.; Malik, B.; Hakeem, K.R. Metagenomic analysis of uncultured microorganisms and their enzymatic attributes. J. Microbiol. Methods 2018, 155, 65-69. [CrossRef] [PubMed]

60. Van der Helm, E.; Genee, H.J.; Sommer, M.O.A. The evolving interface between synthetic biology and functional metagenomics. Nat. Chem. Biol. 2018, 14, 752-759. [CrossRef] [PubMed]

61. Zhou, S.H.; Alper, H.S. Strategies for directed and adapted evolution as part of microbial strain engineering. J. Chem. Technol. Biotechnol. 2019, 94, 366-376. [CrossRef]

62. Zeymer, C.; Hilvert, D. Directed evolution of protein catalysts. In Annual Review of Biochemistry; Kornberg, R.D., Ed.; Annual Reviews: Palo Alto, CA USA, 2018; Volume 87, pp. 131-157.

63. Bornscheuer, U.T.; Hauer, B.; Jaeger, K.E.; Schwaneberg, U. Directed evolution empowered redesign of natural proteins for the sustainable production of chemicals and pharmaceuticals. Angew. Chem. Int. Edit. 2019, 58, 36-40. [CrossRef] [PubMed]

64. Li, G.Y.; Wang, J.B.; Reetz, M.T. Biocatalysts for the pharmaceutical industry created by structure-guided directed evolution of stereoselective enzymes. Bioorg. Med. Chem. 2018, 26, 1241-1251. [CrossRef]

65. Arnold, F.H. Directed Evolution: Bringing New Chemistry to Life. Angew. Chem. Int. Edit. 2018, 57, 4143-4148. [CrossRef] [PubMed]

66. Hernandez, K.; Fernandez-Lafuente, R. Control of protein immobilization: Coupling immobilization and site-directed mutagenesis to improve biocatalyst or biosensor performance. Enzym. Microb. Technol. 2011, 48, 107-122. [CrossRef] [PubMed]

67. Barbosa, O.; Torres, R.; Ortiz, C.; Berenguer-Murcia, A.; Rodrigues, R.C.; Fernandez-Lafuente, R. Heterofunctional supports in enzyme immobilization: From traditional immobilization protocols to opportunities in tuning enzyme properties. Biomacromolecules 2013, 14, 2433-2462. [CrossRef]

68. Cowan, D.A.; Fernandez-Lafuente, R. Enhancing the functional properties of thermophilic enzymes by chemical modification and immobilization. Enzym. Microb. Technol. 2011, 49, 326-346. [CrossRef]

69. Rodrigues, R.C.; Berenguer-Murcia, A.; Fernandez-Lafuente, R. Coupling chemical modification and immobilization to improve the catalytic performance of enzymes. Adv. Synth. Catal. 2011, 353, 2216-2238. [CrossRef] 
70. Rueda, N.; dos Santos, J.C.S.; Ortiz, C.; Torres, R.; Barbosa, O.; Rodrigues, R.C.; Berenguer-Murcia, A.; Fernandez-Lafuente, R. Chemical modification in the design of immobilized enzyme biocatalysts: Drawbacks and opportunities. Chem. Rec. 2016, 16, 1436-1455. [CrossRef] [PubMed]

71. Fernandez-Lafuente, R. Stabilization of multimeric enzymes: Strategies to prevent subunit dissociation. Enzym. Microb. Technol. 2009, 45, 405-418. [CrossRef]

72. BeMiller, J.N. Dextran. In Encyclopedia of Food Sciences and Nutrition, 2nd ed.; Caballero, B., Ed.; Academic Press: Oxford, UK, 2003; pp. 1772-1773. [CrossRef]

73. IUPAC. Dextrans. Available online: https://goldbook.iupac.org/html/D/D01655.html (accessed on 6 May 2019).

74. Sidebotham, R.L. Dextrans. In Advances in Carbohydrate Chemistry and Biochemistry; Tipson, R.S., Horton, D., Eds.; Academic Press: Cambridge, MA, USA, 1974; Volume 30, pp. 371-444.

75. Naessens, M.; Cerdobbel, A.; Soetaert, W.; Vandamme, E.J. Leuconostoc dextransucrase and dextran: Production, properties and applications. J. Chem. Technol. Biotechnol. 2005, 80, 845-860. [CrossRef]

76. Bounaix, M.S.; Gabriel, V.; Robert, H.; Morel, S.; Rernaud-Simeon, M.; Gabriel, B.; Fontagne-Faucher, C. Characterization of glucan-producing Leuconostoc strains isolated from sourdough. Int. J. Food Microbiol. 2010, 144, 1-9. [CrossRef] [PubMed]

77. Fusco, V.; Quero, G.M.; Cho, G.S.; Kabisch, J.; Meske, D.; Neve, H.; Bockelmann, W.; Franz, C. The genus Weissella: Taxonomy, ecology and biotechnological potential. Front. Microbiol. 2015, 6, 22. [CrossRef] [PubMed]

78. Bounaix, M.S.; Robert, H.; Gabriel, V.; Morel, S.; Remaud-Simeon, M.; Gabriel, B.; Fontagne-Faucher, C. Characterization of dextran-producing Weissella strains isolated from sourdoughs and evidence of constitutive dextransucrase expression. FEMS Microbiol. Lett. 2010, 311, 18-26. [CrossRef] [PubMed]

79. Ahmed, Z.; Ahmad, A. Biopolymer Produced by the Lactic Acid Bacteria: Production and Practical Application; Academic Press Ltd-Elsevier Science Ltd.: London, UK, 2017; Volume 5, pp. 217-257.

80. Van Hijum, S.; Kralj, S.; Ozimek, L.K.; Dijkhuizen, L.; van Geel-Schutten, I.G.H. Structure-function relationships of glucansucrase and fructansucrase enzymes from lactic acid bacteria. Microbiol. Mol. Biol. Rev. 2006, 70, 157-176. [CrossRef] [PubMed]

81. Stepanov, N.A.; Senko, O.V.; Efremenko, E.N. Biocatalytic production of extracellular exopolysaccharide dextran synthesized by cells of Leuconostoc mesenteroides. Catal. Ind. 2017, 9, 339-343. [CrossRef]

82. Siddiqui, N.N.; Aman, A.; Silipo, A.; Qader, S.A.U.; Molinaro, A. Structural analysis and characterization of dextran produced by wild and mutant strains of Leuconostoc mesenteroides. Carbohydr. Polym. 2014, 99, 331-338. [CrossRef]

83. Leung, A.D.; Wong, K.H.K.; Tien, J. Plasma expanders stabilize human microvessels in microfluidic scaffolds. J. Biomed. Mater. Res. Part A 2012, 100A, 1815-1822. [CrossRef] [PubMed]

84. McCahon, R.; Hardman, J. Pharmacology of plasma expanders. Anaesth. Intensive Care 2017, 18, 418-420. [CrossRef]

85. Khalikova, E.; Susi, P.; Korpela, T. Microbial dextran-hydrolyzing enzymes: Fundamentals and applications. Microbiol. Mol. Biol. Rev. 2005, 69, 306-325. [CrossRef] [PubMed]

86. Varshosaz, J. Dextran conjugates in drug delivery. Expert Opin. Drug Deliv. 2012, 9, 509-523. [CrossRef] [PubMed]

87. Kirschning, A.; Dibbert, N.; Drager, G. Chemical Functionalization of Polysaccharides-Towards Biocompatible Hydrogels for Biomedical Applications. Chem. Eur. J. 2018, 24, 1231-1240. [CrossRef] [PubMed]

88. Peesa, J.P.; Yalavarthi, P.R.; Rasheed, A.; Mandava, V.B.R. A perspective review on role of novel NSAID prodrugs in the management of acute inflammation. J. Acute Dis. 2016, 5, 364-381. [CrossRef]

89. Larsen, C. Dextran prodrugs-Structure and stability in relation to therapeutic activity. Adv. Drug. Deliv. Rev. 1989, 3, 103-154. [CrossRef]

90. Engelmann, G.; Jobmann, M.; Rafler, G. Dextran carbamates-Materials for microencapsulation. Ind. Crops Prod. 2004, 20, 37-48. [CrossRef]

91. Van Tomme, S.R.; Hennink, W.E. Biodegradable dextran hydrogels for protein delivery applications. Expert Rev. Med. Devices 2007, 4, 147-164. [CrossRef]

92. Mukwaya, V.; Wang, C.L.; Dou, H.J. Saccharide-based nanocarriers for targeted therapeutic and diagnostic applications. Polym. Int. 2019, 68, 306-319. [CrossRef]

93. Huang, S.Y.; Huang, G.L. Preparation and drug delivery of dextran-drug complex. Drug Deliv. 2019, 26, 10. [CrossRef] [PubMed] 
94. Huang, G.L.; Huang, H.L. Application of dextran as nanoscale drug carriers. Nanomedicine 2018, 13, 3149-3158. [CrossRef] [PubMed]

95. Banerjee, A.; Bandopadhyay, R. Use of dextran nanoparticle: A paradigm shift in bacterial exopolysaccharide based biomedical applications. Int. J. Biol. Macromol. 2016, 87, 295-301. [CrossRef] [PubMed]

96. Li, Z.; Wang, L.N.; Lin, X.; Shen, L.; Feng, Y. Drug delivery for bioactive polysaccharides to improve their drug-like properties and curative efficacy. Drug Deliv. 2017, 24, 70-80. [CrossRef] [PubMed]

97. Xu, L.; Gong, Y.S.; Gern, J.E.; Ikeda, S.; Lucey, J.A. Glycation of whey protein with dextrans of different molar mass: Effect on immunoglobulin E-binding capacity with blood sera obtained from patients with cow milk protein allergy. J. Dairy Sci. 2018, 101, 6823-6834. [CrossRef] [PubMed]

98. Nodake, Y.; Fukumoto, S.; Fukasawa, M.; Sakakibara, R.; Yamasaki, N. Reduction of the Immunogenicity of beta-Lactoglobulin from Cow's Milk by Conjugation with a Dextran Derivative. Biosci. Biotech. Bioch. 2010, 74, 721-726. [CrossRef] [PubMed]

99. Maia, J.; Evangelista, M.; Gil, H.; Ferreira, L. Dextran-based materials for biomedical applications. In Carbohydrates Applications in Medicine; Gil, M.H., Ed.; Research Signpost: Trivandrum, India, 2014; pp. 31-53.

100. Tiwari, S.; Patil, R.; Bahadur, P. Polysaccharide Based Scaffolds for Soft Tissue Engineering Applications. Polymers 2019, 11, 1. [CrossRef] [PubMed]

101. Wolf, M.; Koch, T.A.; Bregman, D.B. Effects of iron deficiency anemia and its treatment on fibroblast growth factor 23 and phosphate homeostasis in women. J. Bone Miner. Res. 2013, 28, 1793-1803. [CrossRef] [PubMed]

102. Auerbach, M.; Pappadakis, J.A.; Bahrain, H.; Auerbach, S.A.; Ballard, H.; Dahl, N.V. Safety and efficacy of rapidly administered (one hour) one gram of low molecular weight iron dextran (INFeD) for the treatment of iron deficient anemia. Am. J. Hematol. 2011, 86, 860-862. [CrossRef]

103. Alhareth, K.; Vauthier, C.; Bourasset, F.; Gueutin, C.; Ponchel, G.; Moussa, F. Conformation of surface-decorating dextran chains affects the pharmacokinetics and biodistribution of doxorubicin-loaded nanoparticles. Eur. J. Pharm. Biopharm. 2012, 81, 453-457. [CrossRef]

104. Merdan, T.; Kopecek, J.; Kissel, T. Prospects for cationic polymers in gene and oligonucleotide therapy against cancer. Adv. Drug Deliv. Rev. 2002, 54, 715-758. [CrossRef]

105. Morille, M.; Passirani, C.; Vonarbourg, A.; Clavreul, A.; Benoit, J.P. Progress in developing cationic vectors for non-viral systemic gene therapy against cancer. Biomaterials 2008, 29, 3477-3496. [CrossRef] [PubMed]

106. Lachelt, U.; Wagner, E. Nucleic acid therapeutics using polyplexes: A journey of 50 years (and beyond). Chem. Rev. 2015, 115, 11043-11078. [CrossRef] [PubMed]

107. Togo, Y.; Takahashi, K.; Saito, K.; Kiso, H.; Huang, B.; Tsukamoto, H.; Hyon, S.-H.; Bessho, K. Aldehyded dextran and epsilon-poly (L-lysine) hydrogel as nonviral gene carrier. Stem Cells Int. 2013. [CrossRef] [PubMed]

108. Thomas, J.J.; Rekha, M.R.; Sharma, C.P. Unraveling the intracellular efficacy of dextran-histidine polycation as an efficient nonviral gene delivery system. Mol. Pharm. 2012, 9, 121-134. [CrossRef] [PubMed]

109. Chu, M.; Dong, C.Y.; Zhu, H.Y.; Cai, X.J.; Dong, H.Q.; Ren, T.B.; Su, J.S.; Li, Y.Y. Biocompatible polyethylenimine-graft-dextran catiomer for highly efficient gene delivery assisted by a nuclear targeting ligand. Polym. Chem. 2013, 4, 2528-2539. [CrossRef]

110. Ochrimenko, S.; Vollrath, A.; Tauhardt, L.; Kempe, K.; Schubert, S.; Schubert, U.S.; Fischer, D. Dextran-graft-linear poly(ethylene imine)s for gene delivery: Importance of the linking strategy. Carbohydr. Polym. 2014, 113, 597-606. [CrossRef]

111. Kloypan, C.; Prapan, A.; Suwannasom, N.; Chaiwaree, S.; Kaewprayoon, W.; Steffen, A.; Xiong, Y.; Baisaeng, N.; Georgieva, R.; Baumler, H. Improved oxygen storage capacity of haemoglobin submicron particles by one-pot formulation. Artif. Cells Nanomed. Biotechnol. 2018, 46, S964-S972. [CrossRef]

112. Kloypan, C.; Suwannasom, N.; Chaiwaree, S.; Prapan, A.; Smuda, K.; Baisaeng, N.; Pruss, A.; Georgieva, R.; Baumler, H. In-Vitro haemocompatibility of dextran-protein submicron particles. Artif. Cells Nanomed. Biotechnol. 2019, 47, 241-249. [CrossRef]

113. Zhang, J.; Wang, Y.; Zhang, S.; You, G.X.; Li, P.L.; Wang, Q.; Yu, W.L.; Hu, T.; Zhou, H.; Zhao, L. In vitro and in vivo investigation of the novel Dex-bHb as oxygen carriers. Artif. Cells Nanomed. Biotechnol. 2018, 46, S133-S137. [CrossRef] 
114. Wang, Y.; Zhang, S.; Zhang, J.; Yu, W.L.; Gao, D.W.; Wang, Q.; You, G.X.; Hu, T.; Zhao, L.; Zhou, H. Structural, functional and physiochemical properties of dextran-bovine hemoglobin conjugate as a hemoglobin-based oxygen carrier. Process Biochem. 2017, 60, 67-73. [CrossRef]

115. Dossabhoy, N.R.; Turley, S.; Gascoyne, R.; Tapolyai, M.; Sulaiman, K. Safety of total dose iron dextran infusion in geriatric patients with chronic kidney disease and iron deficiency anemia. Ren. Fail. 2014, 36, 1033-1037. [CrossRef] [PubMed]

116. Cooke, M.; Lamplugh, A.; Naudeer, S.; Edey, M.; Bhandari, S. Efficacy and tolerability of accelerated-dose low-molecular-weight iron dextran (cosmofer) in patients with chronic kidney disease. Am. J. Nephrol. 2012, 35, 69-74. [CrossRef] [PubMed]

117. Yessayan, L.; Sandhu, A.; Besarab, A.; Yessayan, A.; Frinak, S.; Zasuwa, G.; Yee, J. Intravenous iron dextran as a component of anemia management in chronic kidney disease: A report of safety and efficacy. Int. J. Nephrol. 2013, 2013, 9. [CrossRef] [PubMed]

118. Zhang, J.; Wang, Y.; You, G.X.; Wang, Q.; Zhang, S.; Yu, W.L.; Hu, T.; Zhao, L.; Zhou, H. Conjugation with 20kDa dextran decreases the autoxidation rate of bovine hemoglobin. Artif. Cells Nanomed. Biotechnol. 2018, 46, 1436-1443. [CrossRef] [PubMed]

119. Malaprade, L. The oxydation of certain polyhydric alcohol by the application of periodic acid. C. R. Hebd. Seances Acad. Sci. 1928, 186, 382-385.

120. Wang, Z. Malaprade Reaction. In Comprehensive Organic Name Reactions and Reagents; Wang, Z., Ed.; John Wiley \& Sons, Inc.: Hoboken, NJ, USA, 2010. [CrossRef]

121. Kent, P.W. Periodate oxidation in the study of the structure of dextrans. Science 1949, 110, 689-690. [CrossRef] [PubMed]

122. Dimler, R.J.; Wolff, I.A.; Sloan, J.W.; Rist, C.E. Interpretation of periodate oxidation data on degraded dextran. J. Am. Chem. Soc. 1955, 77, 6568-6573. [CrossRef]

123. Maia, J.; Carvalho, R.A.; Coelho, J.F.J.; Simoes, P.N.; Gil, M.H. Insight on the periodate oxidation of dextran and its structural vicissitudes. Polymer 2011, 52, 258-265. [CrossRef]

124. Jeanes, A.; Wilham, C.A. Periodate oxidation of dextran. J. Am. Chem. Soc. 1950, 72, 2655-2657. [CrossRef]

125. Ishak, M.F.; Painter, T.J. Kinetic evidence for hemiacetal formation during oxidation of dextran in aqueous periodate. Carbohydr. Res. 1978, 64, 189-197. [CrossRef]

126. Drobchenko, S.N.; IsaevaIvanova, L.S.; Kleiner, A.R.; Eneyskaya, E.V. Aldo-enol transition in periodate-oxidized dextrans. Carbohydr. Res. 1996, 280, 171-176. [CrossRef]

127. Yu, R.J.; Bishop, C.T. Novel oxidations of methyl glycopyranosides by periodic acid in dimethyl sulfoxide. Can. J. Chem. 1967, 45, 2195-2203. [CrossRef]

128. Maia, J.; Ferreira, L.; Carvalho, R.; Ramos, M.A.; Gil, M.H. Synthesis and characterization of new injectable and degradable dextran-based hydrogels. Polymer 2005, 46, 9604-9614. [CrossRef]

129. Bouhadir, K.H.; Hausman, D.S.; Mooney, D.J. Synthesis of cross-linked poly (aldehyde guluronate) hydrogels. Polymer 1999, 40, 3575-3584. [CrossRef]

130. Lenders, J.P.; Crichton, R.R. Thermal stabilization of amylolytic enzymes by covalent coupling to soluble polysaccharides. Biotechnol. Bioeng. 1984, 26, 1343-1351. [CrossRef] [PubMed]

131. Zhao, H.; Heindel, N.D. Determination of degree of substitution of formyl groups in polyaldehyde dextran by the hydroxylamine hydrochloride method. Pharm. Res. 1991, 8, 400-402. [CrossRef] [PubMed]

132. Al-Noor, T.; El-Ajaily, M.M.; Maihub, A.A. A Review: On Chemistry Important of Schiff's Bases Complexes, 1st ed.; Noor Publishing: Saarbrücken, Germany, 2017.

133. Hermanson, G.T. Bioconjugate Techniques; Elsevier Science \& Technology: San Diego, CA, USA, 2013.

134. Lundblad, R.L.; Lundblad, R.L. Modification of Proteins with Reducing Agents; CRC Press-Taylor \& Francis Group: Boca Raton, FL, USA, 2014; pp. 185-216.

135. Tarasevich, V.A. Reductive amination of oxygen-containing organic compounds. Russ. Chem. Rev. 1999, 68, 55-72. [CrossRef]

136. Baxter, E.W.; Reitz, A.B. Reductive aminations of carbonyl compounds with borohydride and borane reducing agents. In Organic Reactions; Paquette, L., Ed.; John Wiley \& Sons: Hoboken, NJ, USA, 2002; Volume 59, pp. 1-57.

137. Sato, S.; Sakamoto, T.; Miyazawa, E.; Kikugawa, Y. One-pot reductive amination of aldehydes and ketones with alpha-picoline-borane in methanol, in water, and in neat conditions. Tetrahedron 2004, 60, 7899-7906. [CrossRef] 
138. Ruhaak, L.R.; Steenvoorden, E.; Koeleman, C.A.M.; Deelder, A.M.; Wuhrer, M. 2-Picoline-borane: A non-toxic reducing agent for oligosaccharide labeling by reductive amination. Proteomics 2010, 10, 2330-2336. [CrossRef] [PubMed]

139. Cosenza, V.A.; Navarro, D.A.; Stortz, C.A. Usage of alpha-picoline borane for the reductive amination of carbohydrates. Arkivoc 2011, 182-194.

140. Kawase, Y.; Yamagishi, T.; Kato, J.Y.; Kutsuma, T.; Kataoka, T.; Iwakuma, T.; Yokomatsu, T. Reductive alkylation of hydrazine derivatives with alpha-picoline-borane and its applications to the syntheses of useful compounds related to active pharmaceutical ingredients. Synthesis 2014, 46, 455-464.

141. Orrego, A.H.; Romero-Fernandez, M.; Millan-Linares, M.D.; Yust, M.D.; Guisan, J.M.; Rocha-Martin, J. Stabilization of enzymes by multipoint covalent attachment on aldehyde-supports: 2-picoline borane as an alternative reducing agent. Catalysts 2018, 8, 333. [CrossRef]

142. Ruzicka, J.; Carroll, A.D.; Lahdesmaki, I. Immobilization of proteins on agarose beads, monitored in real time by bead injection spectroscopy. Analyst 2006, 131, 799-808. [CrossRef] [PubMed]

143. Chimpibul, W.; Nagashima, T.; Hayashi, F.; Nakajima, N.; Hyon, S.H.; Matsumura, K. Dextran oxidized by a Malaprade reaction shows main chain scission through a Maillard reaction triggered by Schiff base formation between aldehydes and amines. J. Polym. Sci. Pol. Chem. 2016, 54, 2254-2260. [CrossRef]

144. Arslan, A.; Kuzu, H.; Altikatoglu, M. Functional stabilization of cellulase from Aspergillus niger by conjugation with dextran-aldehyde. J. Carbohydr. Chem. 2010, 29, 222-235. [CrossRef]

145. Altikatoglu, M.; Kuzu, H. Water soluble covalent conjugates of Aspergillus oryzae alpha amylase with dextran sulphate and their fluorescence characteristics. Fresenius Environ. Bull. 2009, 18, 2108-2113.

146. Altikatoglu, M.; Arioz, C.; Basaran, Y.; Kuzu, H. Stabilization of horseradish peroxidase by covalent conjugation with dextran aldehyde against temperature and pH changes. Cent. Eur. J. Chem. 2009, 7, 423-428. [CrossRef]

147. Maksimenko, A.V.; Schechilina, Y.V.; Tischenko, E.G. Resistance of dextran-modified hyaluronidase to inhibition by heparin. Biochem. Moscow 2001, 66, 456-463. [CrossRef]

148. Maksimenko, A.V.; Petrova, M.L.; Tischenko, E.G.; Schechilina, Y.V. Chemical modification of hyaluronidase regulates its inhibition by heparin. Eur. J. Pharm. Biopharm. 2001, 51, 33-38. [CrossRef]

149. Venkatesh, R.; Warrier, S.R.; Shubhada, S.; Sundaram, P.V. Monopolyaldehyde-mediated, dipolyaldehyde-mediated, and polyaldehyde-mediated chemical modification of urease. In Enzym. Engineering XI; Clark, D.S., Estell, D.A., Eds.; New York Acad Sciences: New York, NY, USA, 1992; Volume 672, pp. 580-582.

150. Maksimenko, A.V.; Nadirashvili, L.A.; Romaschenko, A.D.; Erkomaishvili, G.S.; Abramova, V.V.; Torchilin, V.P. Complex of papaya proteinases modified with soluble polymer and its possible medical application. J. Control. Release 1989, 10, 131-143. [CrossRef]

151. Lenders, J.P.; Crichton, R.R. Chemical stabilization of glucoamylase from Aspergillus niger against thermal inactivation. Biotechnol. Bioeng. 1988, 31, 267-277. [CrossRef] [PubMed]

152. Maksimenko, A.V.; Grigor'eva, E.L.; Morozkin, A.D.; Tishchenko, E.G.; Minkovskiǔ, E.B.; Torchilin, V.P. Assessment of the composition and structure of covalent complexes of superoxide dismutase with aldehyde dextran by analytical ultracentrifugation. Biokhimiia 1991, 56, 1330-1336. [PubMed]

153. Maksimenko, A.V.; Grigoreva, E.L.; Bezrukavnikova, L.M.; Petrov, A.D.; Tishchenko, E.G.; Arkhipova, O.G.; Torchilin, V.P. Antifibrous action of aldehyde-dextran modified superoxide-dismutase in experimental silicosis. Bull. Exp. Biol. Med. 1991, 112, 1268-1271. [CrossRef]

154. Gutarra, M.L.E.; Romero, O.; Abian, O.; Torres, F.A.G.; Freire, D.M.G.; Castro, A.M.; Guisan, J.M.; Palomo, J.M. Enzyme surface glycosylation in the solid phase: Improved activity and selectivity of Candida antarctica lipase B. ChemCatChem 2011, 3, 1902-1910. [CrossRef]

155. Orrego, A.H.; Ghobadi, R.; Moreno-Perez, S.; Mendoza, A.J.; Fernandez-Lorente, G.; Guisan, J.M.; Rocha-Martin, J. Stabilization of immobilized lipases by intense intramolecular cross-linking of their surfaces by using aldehyde-dextran polymers. Int. J. Mol. Sci. 2018, 19, 553. [CrossRef] [PubMed]

156. Manoel, E.A.; dos Santos, J.C.S.; Freire, D.M.G.; Rueda, N.; Fernandez-Lafuente, R. Immobilization of lipases on hydrophobic supports involves the open form of the enzyme. Enzym. Microb. Technol. 2015, 71, 53-57. [CrossRef] 
157. Rodrigues, R.C.; Virgen-Ortiz, J.J.; Dos Santos, J.C.S.; Berenguer-Murcia, A.; Alcantara, A.R.; Barbosa, O.; Ortiz, C.; Fernandez-Lafuente, R. Immobilization of lipases on hydrophobic supports: Immobilization mechanism, advantages, problems, and solutions. Biotechnol. Adv. 2019, in press. [CrossRef]

158. Carraway, K.L.; Koshland, D.E., Jr. Carbodiimide modification of proteins. In Methods in Enzymology; Academic Press: Cambridge, MA, USA, 1972; Volume 25, pp. 616-623.

159. Rodrigues, R.C.; Barbosa, O.; Ortiz, C.; Berenguer-Murcia, A.; Torres, R.; Fernandez-Lafuente, R. Amination of enzymes to improve biocatalyst performance: Coupling genetic modification and physicochemical tools. RSC Adv. 2014, 4, 38350-38374. [CrossRef]

160. Yano, Y.F. Kinetics of protein unfolding at interfaces. J. Phys. Condens. Matter. 2012, 24, 503101. [CrossRef]

161. Findrik, Z.; Presecki, A.V.; Vasic-Racki, D. The influence of aeration on activity and operational stability of two snake venom amino acid oxidases. Biochem. Eng. J. 2012, 60, 91-98. [CrossRef]

162. Findrik, Z.; Valentovic, I.; Vasic-Racki, D. A mathematical model of oxidative deamination of amino acid catalyzed by two D-amino acid oxidases and influence of aeration on enzyme stability. Appl. Biochem. Biotechnol. 2014, 172, 3092-3105. [CrossRef] [PubMed]

163. Wu, H.; Fan, Y.; Sheng, J.; Sui, S.F. Induction of changes in the secondary structure of globular proteins by a hydrophobic surface. Eur. Biophys. J. 1993, 22, 201-205. [CrossRef] [PubMed]

164. Ross, A.C.; Bell, G.; Halling, P.J. Organic solvent functional group effect on enzyme inactivation by the interfacial mechanism. J. Mol. Catal. B Enzym. 2000, 8, 183-192. [CrossRef]

165. Ghatorae, A.S.; Guerra, M.J.; Bell, G.; Halling, P.J. New technique for monitoring interfacial inactivation of enzymes by organic solvents. In Studies in Organic Chemistry; Elsevier: Amsterdam, The Netherlands, 1993; Volume 47, pp. 329-336.

166. Halling, P.J.; Ross, A.C.; Bell, G. Inactivation of enzymes at the aqueous-organic interface. In Progress in Biotechnology; Elsevier: Amsterdam, The Netherlands, 1998; Volume 15, pp. 365-372.

167. Garcia-Galan, C.; Berenguer-Murcia, A.; Fernandez-Lafuente, R.; Rodrigues, R.C. Potential of different enzyme immobilization strategies to improve enzyme performance. Adv. Synth. Catal. 2011, 353, 2885-2904. [CrossRef]

168. Garcia-Galan, C.; Barbosa, O.; Fernandez-Lafuente, R. Stabilization of the hexameric glutamate dehydrogenase from Escherichia coli by cations and polyethyleneimine. Enzym. Microb. Technol. 2013, 52, 211-217. [CrossRef] [PubMed]

169. Bolivar, J.M.; Rocha-Martin, J.; Mateo, C.; Cava, F.; Berenguer, J.; Fernandez-Lafuente, R.; Guisan, J.M. Coating of soluble and immobilized enzymes with ionic polymers: Full stabilization of the quaternary structure of multimeric enzymes. Biomacromolecules 2009, 10, 742-747. [CrossRef] [PubMed]

170. Montes, T.; Grazu, V.; López-Gallego, F.; Hermoso, J.A.; Guisán, J.M.; Fernández-Lafuente, R. Chemical modification of protein surfaces to improve their reversible enzyme immobilization on ionic exchangers. Biomacromolecules 2006, 7, 3052-3058. [CrossRef] [PubMed]

171. Betancor, L.; Lopez-Gallego, F.; Hidalgo, A.; Alonso-Morales, N.; Fuentes, M.; Fernandez-Lafuente, R.; Guisan, J.M. Prevention of interfacial inactivation of enzymes by coating the enzyme surface with dextran-aldehyde. J. Biotechnol. 2004, 110, 201-207. [CrossRef] [PubMed]

172. Altikatoglu, M.; Celebi, M. Enhanced stability and decolorization of Coomassie Brilliant Blue R-250 by dextran aldehyde-modified horseradish peroxidase. Artif. Cells Blood Substit. Biotechnol. 2011, 39, 185-190. [CrossRef] [PubMed]

173. Betancor, L.; Fuentes, M.; Dellamora-Ortiz, G.; Lopez-Gallego, F.; Hidalgo, A.; Alonso-Morales, N.; Mateo, C.; Guisan, J.M.; Fernandez-Lafuente, R. Dextran aldehyde coating of glucose oxidase immobilized on magnetic nanoparticles prevents its inactivation by gas bubbles. J. Mol. Catal. B Enzym. 2005, 32, 97-101. [CrossRef]

174. Fujihara, M.; Takahashi, D.; Abe, H.; Sakai, H.; Horinouchi, H.; Kobayashi, K.; Ikeda, H.; Azuma, H. Primary and secondary immune responses to keyhole limpet hemocyanin in rats after infusion of hemoglobin vesicle, an artificial oxygen carrier. Artif. Organs 2014, 38, 234-238. [CrossRef] [PubMed]

175. Chapman, P.B.; Morrissey, D.M.; Panageas, K.S.; Hamilton, W.B.; Zhan, C.; Destro, A.N.; Williams, L.; Israel, R.J.; Livingston, P.O. Induction of antibodies against GM2 ganglioside by immunizing melanoma patients using GM2-keyhole limpet hemocyanin + QS21 vaccine: A dose-response study. Clin. Canc. Res. 2000, 6, 874-879. 
176. Adluri, S.; Helling, F.; Ogata, S.; Zhang, S.; Itzkowitz, S.H.; Lloyd, K.O.; Livingston, P.O. Immunogenicity of synthetic TF-KLH (keyhole limpet hemocyanin) and sTn-KLH conjugates in colorectal carcinoma patients. Cancer Immunol. Immunother. 1995, 41, 185-192. [CrossRef] [PubMed]

177. Helling, F.; Shang, A.; Calves, M.; Zhang, S.; Ren, S.; Yu, R.K.; Oettgen, H.F.; Livingston, P.O. GD3 vaccines for melanoma: Superior immunogenicity of keyhole limpet hemocyanin conjugate vaccines. Cancer Res. 1994, 54, 197-203. [PubMed]

178. Fuentes, M.; Mateo, C.; Fernandez-Lafuente, R.; Guisan, J.M. Aldehyde-dextran-protein conjugates to immobilize amino-haptens: Avoiding cross-reactions in the immunodetection. Enzym. Microb. Technol. 2005, 36, 510-513. [CrossRef]

179. Azam, M.G.; Shibata, T.; Kabashima, T.; Kai, M. Sensitive chemiluminescence detection of prion protein on a membrane by using a peroxidase-labeled dextran probe. Anal. Sci. 2011, 27, 715-720. [CrossRef]

180. Shanazarova, I.M.; Vanchugova, L.V.; Valuev, L.I.; Platé, N.A. Interaction of ovomucoid from duck egg proteins with aldehydes-dextrans. Prikl. Biokhim. Mikrobiol. 1992, 28, 292-296.

181. Cao, L.Q.; van Rantwijk, F.; Sheldon, R.A. Cross-linked enzyme aggregates: A simple and effective method for the immobilization of penicillin acylase. Org. Lett. 2000, 2, 1361-1364. [CrossRef]

182. Sheldon, R.A. Cross-linked enzyme aggregates as industrial biocatalysts. Org. Process Res. Dev. 2011, 15, 213-223. [CrossRef]

183. Schoevaart, R.; Wolbers, M.W.; Golubovic, M.; Ottens, M.; Kieboom, A.P.G.; van Rantwijk, F.; van der Wielen, L.A.M.; Sheldon, R.A. Preparation, optimization, and structures of cross-linked enzyme aggregates (CLEAs). Biotechnol. Bioeng. 2004, 87, 754-762. [CrossRef] [PubMed]

184. Sheldon, R.A. Cross-linked enzyme aggregates (CLEA ${ }^{\circledR}$ s): Stable and recyclable biocatalysts. Biochem. Soc. Trans. 2007, 35, 1583-1587. [CrossRef] [PubMed]

185. Sheldon, R.A. Enzyme immobilization: The quest for optimum performance. Adv. Synth. Catal. 2007, 349, 1289-1307. [CrossRef]

186. Tukel, S.S.; Hurrem, F.; Yildirim, D.; Alptekin, O. Preparation of crosslinked enzyme aggregates (CLEA) of catalase and its characterization. J. Mol. Catal. B Enzym. 2013, 97, 252-257. [CrossRef]

187. Araujo-Silva, R.; Mafra, A.C.O.; Rojas, M.J.; Kopp, W.; Giordano, R.D.; Fernandez-Lafuente, R.; Tardioli, P.W. Maltose production using starch from cassava bagasse catalyzed by cross-linked beta-amylase aggregates. Catalysts 2018, 8, 170. [CrossRef]

188. Ramos, M.D.; Miranda, L.P.; Giordano, R.L.C.; Fernandez-Lafuente, R.; Kopp, W.; Tardioli, P.W. 1, 3-Regiospecific ethanolysis of soybean oil catalyzed by crosslinked porcine pancreas lipase aggregates. Biotechnol. Prog. 2018, 34, 910-920. [CrossRef] [PubMed]

189. Amaral-Fonseca, M.; Kopp, W.; Giordano, R.D.C.; Fernandez-Lafuente, R.; Tardioli, P.W. Preparation of magnetic cross-linked amyloglucosidase aggregates: Solving some activity problems. Catalysts 2018, 8, 496. [CrossRef]

190. Torres, M.D.G.; Foresti, M.L.; Ferreira, M.L. Cross-linked enzyme aggregates (CLEAs) of selected lipases: A procedure for the proper calculation of their recovered activity. AMB Express 2013, 3, 11.

191. Rojas, M.J.; Amaral-Fonseca, M.; Zanin, G.M.; Fernandez-Lafuente, R.; Giordano, R.D.C.; Tardioli, P.W. Preparation of crosslinked enzyme aggregates of a thermostable cyclodextrin glucosyltransferase from Thermoanaerobacter sp. Critical effect of the crosslinking agent. Catalysts 2019, 9, 120. [CrossRef]

192. Tirunagari, H.; Basetty, S.; Rode, H.B.; Fadnavis, N.W. Crosslinked enzyme aggregates (CLEA) of phytase with soymilk proteins. J. Biotechnol. 2018, 282, 67-69. [CrossRef] [PubMed]

193. Cruz, J.; Barbosa, O.; Rodrigues, R.C.; Fernandez-Lafuente, R.; Torres, R.; Ortiz, C. Optimized preparation of CALB-CLEAs by response surface methodology: The necessity to employ a feeder to have an effective crosslinking. J. Mol. Catal. B Enzym. 2012, 80, 7-14. [CrossRef]

194. Lopez-Gallego, F.; Betancor, L.; Hidalgo, A.; Alonso, N.; Fernandez-Lafuente, R.; Guisan, J.M. Co-aggregation of enzymes and polyethyleneimine: A simple method to prepare stable and immobilized derivatives of glutaryl acylase. Biomacromolecules 2005, 6, 1839-1842. [CrossRef] [PubMed]

195. Yan, J.; Gui, X.; Wang, G.; Yan, Y. Improving stability and activity of cross-linked enzyme aggregates based on polyethylenimine in hydrolysis of fish oil for enrichment of polyunsaturated fatty acids. Appl. Biochem. Biotechnol. 2012, 166, 925-932. [CrossRef] [PubMed] 
196. Galvis, M.; Barbosa, O.; Ruiz, M.; Cruz, J.; Ortiz, C.; Torres, R.; Fernandez-Lafuente, R. Chemical amination of lipase $\mathrm{B}$ from Candida antarctica is an efficient solution for the preparation of crosslinked enzyme aggregates. Process Biochem. 2012, 47, 2373-2378. [CrossRef]

197. Vaidya, B.K.; Kuwar, S.S.; Golegaonkar, S.B.; Nene, S.N. Preparation of cross-linked enzyme aggregates of L-aminoacylase via co-aggregation with polyethyleneimine. J. Mol. Catal. B Enzym. 2012, 74, 184-191. [CrossRef]

198. Pan, J.A.; Kong, X.D.; Li, C.X.; Ye, Q.; Xu, J.H.; Imanaka, T. Crosslinking of enzyme coaggregate with polyethyleneimine: A simple and promising method for preparing stable biocatalyst of Serratia marcescens lipase. J. Mol. Catal. B Enzym. 2011, 68, 256-261. [CrossRef]

199. Velasco-Lozano, S.; Lopez-Gallego, F.; Vazquez-Duhalt, R.; Mateos-Diaz, J.C.; Guisan, J.M.; Favela-Torres, E. Carrier-free immobilization of lipase from Candida rugosa with polyethyleneimines by carboxyl-activated cross-linking. Biomacromolecules 2014, 15, 1896-1903. [CrossRef] [PubMed]

200. Migneault, I.; Dartiguenave, C.; Bertrand, M.J.; Waldron, K.C. Glutaraldehyde: Behavior in aqueous solution, reaction with proteins, and application to enzyme crosslinking. BioTechniques 2004, 37, 790-802. [CrossRef]

201. Barbosa, O.; Ortiz, C.; Berenguer-Murcia, A.; Torres, R.; Rodrigues, R.C.; Fernandez-Lafuente, R. Glutaraldehyde in bio-catalysts design: A useful crosslinker and a versatile tool in enzyme immobilization. RSC Adv. 2014, 4, 1583-1600. [CrossRef]

202. Valdes, E.C.; Soto, L.W.; Arcaya, G.A. Influence of the $\mathrm{pH}$ of glutaraldehyde and the use of dextran aldehyde on the preparation of cross-linked enzyme aggregates (CLEAs) of lipase from Burkholderia cepacia. Electron. J. Biotechnol. 2011, 14, 7. [CrossRef]

203. Mateo, C.; Palomo, J.M.; van Langen, L.M.; van Rantwijk, F.; Sheldon, R.A. A new, mild cross-linking methodology to prepare cross-linked enzyme aggregates. Biotechnol. Bioeng. 2004, 86, 273-276. [CrossRef] [PubMed]

204. Kim, M.H.; Park, S.; Kim, Y.H.; Won, K.; Lee, S.H. Immobilization of formate dehydrogenase from Candida boidinii through cross-linked enzyme aggregates. J. Mol. Catal. B Enzym. 2013, 97, 209-214. [CrossRef]

205. Nadar, S.S.; Rathod, V.K. Magnetic macromolecular cross linked enzyme aggregates (CLEAs) of glucoamylase. Enzym. Microb. Technol. 2016, 83, 78-87. [CrossRef] [PubMed]

206. Ba, S.; Haroune, L.; Cruz-Morato, C.; Jacquet, C.; Touahar, I.E.; Bellenger, J.P.; Legault, C.Y.; Jones, J.P.; Cabana, H. Synthesis and characterization of combined cross-linked laccase and tyrosinase aggregates transforming acetaminophen as a model phenolic compound in wastewaters. Sci. Total Environ. 2014, 487, 748-755. [CrossRef] [PubMed]

207. Ortiz-Soto, M.E.; Rudino-Pinera, E.; Rodriguez-Alegria, M.E.; Munguia, A.L. Evaluation of cross-linked aggregates from purified Bacillus subtilis levansucrase mutants for transfructosylation reactions. BMC Biotechnol. 2009, 9, 8. [CrossRef] [PubMed]

208. Nguyen, L.T.; Yang, K.L. Combined cross-linked enzyme aggregates of horseradish peroxidase and glucose oxidase for catalyzing cascade chemical reactions. Enzym. Microb. Technol. 2017, 100, 52-59. [CrossRef] [PubMed]

209. Zhen, Q.N.; Wang, M.F.; Qi, W.; Su, R.X.; He, Z.M. Preparation of beta-mannanase CLEAs using macromolecular cross-linkers. Catal. Sci. Technol. 2013, 3, 1937-1941. [CrossRef]

210. Nadar, S.S.; Muley, A.B.; Ladole, M.R.; Joshi, P.U. Macromolecular cross-linked enzyme aggregates (M-CLEAs) of alpha-amylase. Int. J. Biol. Macromol. 2016, 84, 69-78. [CrossRef] [PubMed]

211. Sahutoglu, A.S.; Akgul, C. Immobilisation of Aspergillus oryzae alpha-amylase and Aspergillus niger glucoamylase enzymes as cross-linked enzyme aggregates. Chem. Pap. 2015, 69, 433-439. [CrossRef]

212. Qin, Y.Z.; Ye, M.; Li, N.; Zong, M.H. Preparation, characterization, and application of cross-linked enzyme aggregates of $\beta$-glycosidases from bovine liver. Mod. Food Sci. Technol. 2015, 31, 210-214.

213. Do, M.Q.; Henry, E.; Kato, M.; Cheruzel, L. Cross-linked cytochrome P450 BM3 aggregates promoted by Ru (II)-diimine complexes bearing aldehyde groups. J. Inorg. Biochem. 2018, 186, 130-134. [CrossRef] [PubMed]

214. Martwiset, S.; Koh, A.E.; Chen, W. Nonfouling characteristics of dextran-containing surfaces. Langmuir 2006, 22, 8192-8196. [CrossRef] [PubMed]

215. Pessela, B.C.C.; Vian, A.; Mateo, U.; Fernandez-Lafuente, R.; Garcia, J.L.; Guisan, J.M.; Carrascosa, A.V. Overproduction of Thermus sp strain T2 beta-galactosidase in Escherichia coli and preparation by using tailor-made metal chelate supports. Appl. Environ. Microbiol. 2003, 69, 1967-1972. [CrossRef] [PubMed] 
216. Pessela, B.C.C.; Mateo, C.; Filho, M.; Carrascosa, A.; Fernandez-Lafuente, R.; Guisan, J.M. Selective adsorption of large proteins on highly activated IMAC supports in the presence of high imidazole concentrations: Purification, reversible immobilization and stabilization of thermophilic alpha-and beta-galactosidases. Enzym. Microb. Technol. 2007, 40, 242-248. [CrossRef]

217. Murza, A.; Fernández-Lafuente, R.; Guisán, J.M. Essential role of the concentration of immobilized ligands in affinity chromatography: Purification of guanidinobenzoatase on an ionized ligand. J. Chromatogr. B Biomed. Sci. Appl. 2000, 740, 211-218. [CrossRef]

218. Sulkowski, E. Purification of proteins by IMAC. Trends Biotechnol. 1985, 3, 1-7. [CrossRef]

219. Franken, K.; Hiemstra, H.S.; van Meijgaarden, K.E.; Subronto, Y.; den Hartigh, J.; Ottenhoff, T.H.M.; Drijfhout, J.W. Purification of His-tagged proteins by immobilized chelate affinity chromatography: The benefits from the use of organic solvent. Protein Expr. Purif. 2000, 18, 95-99. [CrossRef]

220. Hemdan, E.S.; Zhao, Y.J.; Sulkowski, E.; Porath, J. Surface-topography of histidine-residues-A facile probe by immobilized metal-ion affinity-chromatography. Proc. Natl. Acad. Sci. USA 1989, 86, 1811-1815. [CrossRef]

221. Porath, J. Immobilized metal ion affinity chromatography. Protein Expr. Purif. 1992, 3, 263-281. [CrossRef]

222. Porath, J.; Carlsson, J.; Olsson, I.; Belfrage, G. Metal chelate affinity chromatography, a new approach to protein fractionation. Nature 1975, 258, 598-599. [CrossRef]

223. Wong, J.W.; Albright, R.L.; Wang, N.H.L. Immobilized metal-ion affinity-chromatography (imac) chemistry and bioseparation applications. Sep. Purif. Methods 1991, 20, 49-106. [CrossRef]

224. Armisén, P.; Mateo, C.; Cortés, E.; Barredo, J.L.; Salto, F.; Diez, B.; Rodés, L.; García, J.L.; Fernández-Lafuente, R.; Guisán, J.M. Selective adsorption of poly-His tagged glutaryl acylase on tailor-made metal chelate supports. J. Chromatogr. A 1999, 848, 61-70. [CrossRef]

225. Mateo, C.; Fernandez-Lorente, G.; Pessela, B.C.C.; Vian, A.; Carrascosa, A.V.; Garcia, J.L.; Fernandez-Lafuente, R.; Guisan, J.M. Affinity chromatography of polyhistidine tagged enzymes-New dextran-coated immobilized metal ion affinity chromatography matrices for prevention of undesired multipoint adsorptions. J. Chromatogr. A 2001, 915, 97-106. [CrossRef]

226. Fuentes, M.; Mateo, C.; Pessela, B.C.C.; Batalla, P.; Fernandez-Lafuente, R.; Guisan, J.M. Solid phase proteomics: Dramatic reinforcement of very weak protein-protein interactions. J. Chromatogr. B 2007, 849, 243-250. [CrossRef] [PubMed]

227. Bolivar, J.M.; Batalla, P.; Mateo, C.; Carrascosa, A.V.; Pessela, B.C.; Guisan, J.M. Selective adsorption of small proteins on large-pore anion exchangers coated with medium size proteins. Colloid Surf. B Biointerfaces 2010, 78, 140-145. [CrossRef] [PubMed]

228. Mateo, C.; Palomo, J.M.; Fuentes, M.; Betancor, L.; Grazu, V.; Lopez-Gallego, F.; Pessela, B.C.C.; Hidalgo, A.; Fernandez-Lorente, G.; Fernandez-Lafuente, R.; et al. Glyoxyl agarose: A fully inert and hydrophilic support for immobilization and high stabilization of proteins. Enzym. Microb. Technol. 2006, 39, 274-280. [CrossRef]

229. Bhalla, N.; Jolly, P.; Formisano, N.; Estrela, P. Introduction to biosensors. In Biosensor Technologies for Detection of Biomolecules; Estrela, P., Ed.; Portland Press Ltd.: London, UK, 2016; Volume 60, pp. 1-8.

230. Batalla, P.; Fuentes, M.; Grazu, V.; Mateo, C.; Fernandez-Lafuente, R.; Guisan, J.M. Oriented covalent immobilization of antibodies on physically inert and hydrophilic support surfaces through their glycosidic chains. Biomacromolecules 2008, 9, 719-723. [CrossRef]

231. Kang, J.H.; Choi, H.J.; Hwang, S.Y.; Han, S.H.; Jeon, J.Y.; Lee, E.K. Improving immunobinding using oriented immobilization of an oxidized antibody. J. Chromatogr. A 2007, 1161, 9-14. [CrossRef]

232. Nisnevitch, M.; Firer, M.A. The solid phase in affinity chromatography: Strategies for antibody attachment. J. Biochem. Biophys. Methods 2001, 49, 467-480. [CrossRef]

233. Shmanai, V.V.; Nikolayeva, T.A.; Vinokurova, L.G.; Litoshka, A.A. Oriented antibody immobilization to polystyrene macrocarriers for immunoassay modified with hydrazide derivatives of poly (meth) acrylic acid. BMC Biotechnol. 2001, 1, 4. [CrossRef]

234. Weiping, Q.; Bin, X.; Lei, W.; Chunxiao, W.; Danfeng, Y.; Fang, Y.; Chunwei, Y.; Yu, W. Controlled site-directed assembly of antibodies by their oligosaccharide moieties onto APTES derivatized surfaces. J. Colloid Interface Sci. 1999, 214, 16-19. [CrossRef]

235. Jesionowski, T.; Zdarta, J.; Krajewska, B. Enzyme immobilization by adsorption: A review. Adsorpt. J. Int. Adsorpt. Soc. 2014, 20, 801-821. [CrossRef]

236. Fuentes, M.; Mateo, C.; Guisan, J.M.; Fernandez-Lafuente, R. Preparation of inert magnetic nano-particles for the directed immobilization of antibodies. Biosens. Bioelectron. 2005, 20, 1380-1387. [CrossRef] [PubMed] 
237. Fuentes, M.; Mateo, C.; Rodriguez, A.; Casqueiro, M.; Tercero, J.C.; Riese, H.H.; Fernandez-Lafuente, R.; Guisan, J.M. Detecting minimal traces of DNA using DNA covalently attached to superparamagnetic nanoparticles and direct PCR-ELISA. Biosens. Bioelectron. 2006, 21, 1574-1580. [CrossRef] [PubMed]

238. Xiao, X.; Yang, X.; Liu, T.; Chen, Z.; Chen, L.L.; Li, H.D.; Deng, L. Preparing a highly specific inert immunomolecular-magnetic beads for rapid detection and separation of S. aureus and group G Streptococcus. Appl. Microbiol. Biotechnol. 2007, 75, 1209-1216. [CrossRef]

239. Farrell, M.; Beaudoin, S. Surface forces and protein adsorption on dextran- and polyethylene glycol-modified polydimethylsiloxane. Colloid Surf. B Biointerfaces 2010, 81, 468-475. [CrossRef]

240. Bi, Y.C.; Yu, M.; Zhou, H.Y.; Zhou, H.; Wei, P. Biosynthesis of oleyl oleate in solvent-free system by Candida rugosa Lipase (CRL) immobilized in macroporous resin with cross-linking of aldehyde-dextran. J. Mol. Catal. B Enzym. 2016, 133, 1-5. [CrossRef]

241. Avseenko, N.V.; Morozova, T.Y.; Ataullakhanov, F.I.; Morozov, V.N. Immobilization of proteins in immunochemical microarrays fabricated by electrospray deposition. Anal. Chem. 2001, 73, 6047-6052. [CrossRef]

242. Nouaimi, M.; Möschel, K.; Bisswanger, H. Immobilization of trypsin on polyester fleece via different spacers. Enzym. Microb. Technol. 2001, 29, 567-574. [CrossRef]

243. Matthijs, G.; Schacht, E. Comparative study of methodologies for obtaining $\beta$-glucosidase immobilized on dextran-modified silica. Enzym. Microb. Technol. 1996, 19, 601-605. [CrossRef]

244. Moser, I.; Dworsky, P.; Pittner, F. Degradation of bacterial-cell walls by immobilized lysozyme. Appl. Biochem. Biotechnol. 1988, 19, 243-249. [CrossRef] [PubMed]

245. Germain, P.; Crichton, R.R. Characterization of a chemically modified $\beta$-amylase immobilized on porous silica. J. Chem. Technol. Biotechnol. 1988, 41, 297-315. [CrossRef]

246. Palubinskas, V.I.; Yankevich, N.B.; Yanulaitene, K.K.; Vesa, V.S.; Bendikene, V.G.; Maksimenko, A.V.; Torchilin, V.P.; Ilyina, E.V.; Smirnov, V.N.; Krestyanova, I.N.; et al. Trypsin-like-enzyme from Streptomyces-771-Purification and properties of native and immobilized enzyme. Appl. Biochem. Biotechnol. 1984, 9, 231-241. [CrossRef] [PubMed]

247. Penzol, G.; Armisen, P.; Fernandez-Lafuente, R.; Rodes, L.; Guisan, J.M. Use of dextrans as long and hydrophilic spacer arms to improve the performance of immobilized proteins acting on macromolecules. Biotechnol. Bioeng. 1998, 60, 518-523. [CrossRef]

248. Azam, M.G.; Shibata, T.; Kabashima, T.; Kai, M. Alkaline phosphatase-labeled macromolecular probe for sensitive chemiluminescence detection of proteins on a solid-phase membrane. Anal. Bioanal. Chem. 2011, 401, 1211-1217. [CrossRef] [PubMed]

249. Alvaro, G.; Fernandez-Lafuente, R.; Blanco, R.M.; Guisán, J.M. Immobilization-stabilization of Penicillin G acylase from Escherichia coli. Appl. Biochem. Biotechnol. 1990, 26, 181-195. [CrossRef]

250. Abian, O.; Grazú, V.; Hermoso, J.; González, R.; García, J.L.; Fernández-Lafuente, R.; Guisán, J.M. Stabilization of penicillin G acylase from Escherichia coli: Site-directed mutagenesis of the protein surface to increase multipoint covalent attachment. Appl. Environ. Microbiol. 2004, 70, 1249-1251. [CrossRef]

251. Fernandez-Lafuente, R.; Rosell, C.M.; Caanan-Haden, L.; Rodes, L.; Guisan, J.M. Facile synthesis of artificial enzyme nano-environments via solid-phase chemistry of immobilized derivatives: Dramatic stabilization of penicillin acylase versus organic solvents. Enzym. Microb. Technol. 1999, 24, 96-103. [CrossRef]

252. Virgen-Ortíz, J.J.; Dos Santos, J.C.S.; Berenguer-Murcia, Á.; Barbosa, O.; Rodrigues, R.C.; Fernandez-Lafuente, R. Polyethylenimine: A very useful ionic polymer in the design of immobilized enzyme biocatalysts. J. Mater. Chem. B 2017, 5, 7461-7490. [CrossRef]

253. Abian, O.; Wilson, L.; Mateo, C.; Fernandez-Lorente, G.; Palomo, J.M.; Fernandez-Lafuente, R.; Guisan, J.M.; Re, D.; Tam, A.; Daminatti, M. Preparation of artificial hyper-hydrophilic micro-environments (polymeric salts) surrounding enzyme molecules-New enzyme derivatives to be used in any reaction medium. J. Mol. Catal. B Enzym. 2002, 19, 295-303. [CrossRef]

254. Abian, O.; Mateo, C.; Fernandez-Lorente, G.; Palomo, J.M.; Fernandez-Lafuente, R.; Guisan, J.M. Stabilization of immobilized enzymes against water-soluble organic cosolvents and generation of hyper-hydrophilic micro-environments surrounding enzyme molecules. Biocatal. Biotransform. 2001, 19, 489-503. [CrossRef]

255. Abian, O.; Mateo, C.; Fernandez-Lorente, G.; Guisan, J.M.; Fernandez-Lafuente, R. Improving the industrial production of 6-APA: Enzymatic hydrolysis of penicillin G in the presence of organic solvents. Biotechnol. Prog. 2003, 19, 1639-1642. [CrossRef] [PubMed] 
256. Abian, O.; Mateo, C.; Fernandez-Lorente, G.; Guisan, J.M.; Fernandez-Lafuente, R. Thermodynamically controlled synthesis of amide bonds catalyzed by highly organic solvent-resistant penicillin acylase derivatives. Biotechnol. Prog. 2004, 20, 117-121. [CrossRef] [PubMed]

257. Abian, O.; Mateo, C.; Palomo, J.M.; Fernandez-Lorente, G.; Guisian, J.M.; Fernandez-Lafuente, R. Enantioselective synthesis of phenylacetamides in the presence of high organic cosolvent concentrations catalyzed by stabilized penicillin G acylase. Effect of the acyl donor. Biotechnol. Prog. 2004, 20, 984-988. [CrossRef] [PubMed]

258. Irazoqui, G.; Giacomini, C.; Batista-Viera, F.; Brena, B.M. Hydrophilization of immobilized model enzymes suggests a widely applicable method for enhancing protein stability in polar organic co-solvents. J. Mol. Catal. B Enzym. 2007, 46, 43-51. [CrossRef]

259. Fernández-Lafuente, R.; Rodríguez, V.; Mateo, C.; Fernández-Lorente, G.; Arminsen, P.; Sabuquillo, P.; Guisán, J.M. Stabilization of enzymes (D-amino acid oxidase) against hydrogen peroxide via immobilization and post-immobilization techniques. J. Mol. Catal. B Enzym. 1999, 7, 173-179. [CrossRef]

260. Lencki, R.W.; Arul, J.; Neufeld, R.J. Effect of subunit dissociation, denaturation, aggregation, coagulation, and decomposition on enzyme inactivation kinetics: II. Biphasic and grace period behavior. Biotechnol. Bioeng. 1992, 40, 1427-1434. [CrossRef] [PubMed]

261. Bechtold, M.; Panke, S. Model-based characterization of operational stability of multimeric enzymes with complex deactivation behavior: An in-silico investigation. Chem. Eng. Sci. 2012, 80, 435-450. [CrossRef]

262. Vrábel, P.; Polakovič, M.; Báleš, V. Modelling of inactivation phenomena in oligomeric enzymes. Comput. Chem. Eng. 1994, 18, S681-S685. [CrossRef]

263. Ahern, T.J.; Casal, J.I.; Petsko, G.A.; Klibanov, A.M. Control of oligomeric enzyme thermostability by protein engineering. Proc. Natl. Acad. Sci. USA 1987, 84, 675-679. [CrossRef] [PubMed]

264. Peimbert, M.; Dominguez-Ramirez, L.; Fernandez-Velasco, D.A. Hydrophobic repacking of the dimer interface of triosephosphate isomerase by in silico design and directed evolution. Biochemistry 2008, 47, 5556-5564. [CrossRef] [PubMed]

265. Kabashima, T.; Li, Y.; Kanada, N.; Ito, K.; Yoshimoto, T. Enhancement of the thermal stability of pyroglutamyl peptidase I by introduction of an intersubunit disulfide bond. Biochim. Biophys. Acta Protein Struct. Molec. Enzym. 2001, 1547, 214-220. [CrossRef]

266. Velanker, S.S.; Gokhale, R.S.; Ray, S.S.; Gopal, B.; Parthasarathy, S.; Santi, D.V.; Balaram, P.; Murthy, M.R.N. Disulfide engineering at the dimer interface of Lactobacillus casei thymidylate synthase: Crystal structure of the T155C/E188C/C244T mutant. Protein Sci. 1999, 8, 930-933. [CrossRef] [PubMed]

267. Wilson, L.; Betancor, L.; Fernandez-Lorente, G.; Fuentes, M.; Hidalgo, A.; Guisan, J.M.; Pessela, B.C.C.; Fernandez-Lafuente, R. Cross-linked aggregates of multimeric enzymes: A simple and efficient methodology to stabilize their quaternary structure. Biomacromolecules 2004, 5, 814-817. [CrossRef] [PubMed]

268. Bolivar, J.M.; Wilson, L.; Ferrarotti, S.A.; Guisan, J.M.; Fernandez-Lafuente, R.; Mateo, C. Improvement of the stability of alcohol dehydrogenase by covalent immobilization on glyoxyl-agarose. J. Biotechnol. 2006, 125, 85-94. [CrossRef] [PubMed]

269. Gouin, S.G.; Fernandez, J.M.G.; Vanquelef, E.; Dupradeau, F.Y.; Salomonsson, E.; Leffler, H.; Ortega-Munoz, M.; Nilsson, U.J.; Kovensky, J. Multimeric lactoside "click clusters" as tools to investigate the effect of linker length in specific interactions with peanut lectin, galectin-1, and-3. ChemBiochem 2010, 11, 1430-1442. [CrossRef] [PubMed]

270. Aissaoui, N.; Landoulsi, J.; Bergaoui, L.; Boujday, S.; Lambert, J.F. Catalytic activity and thermostability of enzymes immobilized on silanized surface: Influence of the crosslinking agent. Enzym. Microb. Technol. 2013, 52, 336-343. [CrossRef] [PubMed]

271. Fernández-Lafuente, R.; Rodríguez, V.; Mateo, C.; Penzol, G.; Hernández-Justiz, O.; Irazoqui, G.; Villarino, A.; Ovsejevi, K.; Batista, F.; Guisán, J.M. Stabilization of multimeric enzymes via immobilization and post-immobilization techniques. J. Mol. Catal. B Enzym. 1999, 7, 181-189. [CrossRef]

272. Balcao, V.M.; Mateo, C.; Fernandez-Lafuente, R.; Malcata, F.X.; Guisan, J.M. Structural and functional stabilization of L-asparaginase via multisubunit immobilization onto highly activated supports. Biotechnol. Prog. 2001, 17, 537-542. [CrossRef] 
273. Fernandez-Lafuente, R.; Hernandez-Justiz, O.; Mateo, C.; Terreni, M.; Fernandez-Lorente, G.; Moreno, M.A.; Alonso, J.; Garcia-Lopez, J.L.; Guisan, J.M. Biotransformations catalyzed by multimeric enzymes: Stabilization of tetrameric ampicillin acylase permits the optimization of ampicillin synthesis under dissociation conditions. Biomacromolecules 2001, 2, 95-104. [CrossRef]

274. Hidalgo, A.; Betancor, L.; Lopez-Gallego, F.; Moreno, R.; Berenguer, J.; Fernández-Lafuente, R.; Guisán, J.M. Design of an immobilized preparation of catalase from Thermus thermophilus to be used in a wide range of conditions.: Structural stabilization of a multimeric enzyme. Enzym. Microb. Technol. 2003, 33, $278-285$. [CrossRef]

275. Betancor, L.; Hidalgo, A.; Fernandez-Lorente, G.; Mateo, C.; Fernandez-Lafuente, R.; Guisan, J.M. Preparation of a stable biocatalyst of bovine liver catalase using immobilization and postimmobilization techniques. Biotechnol. Prog. 2003, 19, 763-767. [CrossRef]

276. Kaddour, S.; Lopez-Gallego, F.; Sadoun, T.; Fernandez-Lafuente, R.; Guisan, J.M. Preparation of an immobilized-stabilized catalase derivative from Aspergillus niger having its multimeric structure stabilized: The effect of $\mathrm{Zn}^{2+}$ on enzyme stability. J. Mol. Catal. B Enzym. 2008, 55, 142-145. [CrossRef]

277. Terrasan, C.R.F.; Trobo-Maseda, L.; Moreno-Perez, S.; Carmona, E.C.; Pessela, B.C.; Guisan, J.M. Co-immobilization and stabilization of xylanase, beta-xylosidase and alpha-L-arabinofuranosidase from Penicillium janczewskii for arabinoxylan hydrolysis. Process Biochem. 2016, 51, 614-623. [CrossRef]

278. Rocha-Martin, J.; Acosta, A.; Berenguer, J.; Guisan, J.M.; Lopez-Gallego, F. Selective oxidation of glycerol to 1,3-dihydroxyacetone by covalently immobilized glycerol dehydrogenases with higher stability and lower product inhibition. Bioresour. Technol. 2014, 170, 445-453. [CrossRef]

279. Serra, I.; Conti, S.; Piskur, J.; Clausen, A.R.; Munch-Petersen, B.; Terreni, M.; Ubiali, D. Immobilized Drosophila melanogaster deoxyribonucleoside kinase (DmdNK) as a high performing biocatalyst for the synthesis of purine arabinonucleotides. Adv. Synth. Catal. 2014, 356, 563-570. [CrossRef]

280. Lopez-Gallego, F.; Betancor, L.; Hidalgo, A.; Dellamora-Ortiz, G.; Mateo, C.; Fernandez-Lafuente, R.; Guisan, J.M. Stabilization of different alcohol oxidases via immobilization and post immobilization techniques. Enzym. Microb. Technol. 2007, 40, 278-284. [CrossRef]

281. Li, D.; Zhao, Y.; Fei, T.; Wang, Y.; Lee, B.H.; Shim, J.H.; Xu, B.; Li, Z.; Li, X. Effects of Streptococcus thermophilus GtfB enzyme on dough rheology, bread quality and starch digestibility. Food Hydrocoll. 2019, 96, 134-139. [CrossRef]

282. Bala, A.; Singh, B. Cellulolytic and xylanolytic enzymes of thermophiles for the production of renewable biofuels. Renew. Energy 2019, 136, 1231-1244. [CrossRef]

283. Atalah, J.; Caceres-Moreno, P.; Espina, G.; Blamey, J.M. Thermophiles and the applications of their enzymes as new biocatalysts. Bioresour. Technol. 2019, 280, 478-488. [CrossRef]

284. Han, H.W.; Ling, Z.M.; Khan, A.; Virk, A.K.; Kulshrestha, S.; Li, X.K. Improvements of thermophilic enzymes: From genetic modifications to applications. Bioresour. Technol. 2019, 279, 350-361. [CrossRef] [PubMed]

285. Karnaouri, A.; Antonopoulou, I.; Zerva, A.; Dimarogona, M.; Topakas, E.; Rova, U.; Christakopoulos, P. Thermophilic enzyme systems for efficient conversion of lignocellulose to valuable products: Structural insights and future perspectives for esterases and oxidative catalysts. Bioresour. Technol. 2019, 279, 362-372. [CrossRef] [PubMed]

286. Bhalla, A.; Bansal, N.; Kumar, S.; Bischoff, K.M.; Sani, R.K. Improved lignocellulose conversion to biofuels with thermophilic bacteria and thermostable enzymes. Bioresour. Technol. 2013, 128, 751-759. [CrossRef] [PubMed]

287. Turner, P.; Mamo, G.; Karlsson, E.N. Potential and utilization of thermophiles and thermostable enzymes in biorefining. Microb. Cells Fact. 2007, 6, 23. [CrossRef] [PubMed]

288. Wolf-Watz, M.; Thai, V.; Henzler-Wildman, K.; Hadjipavlou, G.; Eisenmesser, E.Z.; Kern, D. Linkage between dynamics and catalysis in a thermophilic-mesophilic enzyme pair. Nat. Struct. Mol. Biol. 2004, 11, $945-949$. [CrossRef] [PubMed]

289. Pessela, B.C.; Mateo, C.; Filho, M.; Carrascosa, A.V.; Fernandez-Lafuente, R.; Guisan, J.M. Stabilization of the quaternary structure of a hexameric alpha-galactosidase from Thermus sp T2 by immobilization and post-immobilization techniques. Process Biochem. 2008, 43, 193-198. [CrossRef] 
290. Pessela, B.C.C.; Mateo, C.; Fuentes, M.; Vian, A.; Garcia, J.L.; Carrascosa, A.V.; Guisan, J.M.; Fernandez-Lafuente, R. Stabilization of a multimeric beta-galactosidase from Thermus sp strain T2 by immobilization on novel heterofunctional epoxy supports plus aldehyde-dextran cross-linking. Biotechnol. Prog. 2004, 20, 388-392. [CrossRef]

291. Terrasan, C.R.F.; Aragon, C.C.; Masui, D.C.; Pessela, B.C.; Fernandez-Lorente, G.; Carmona, E.C.; Guisan, J.M. beta-xylosidase from Selenomonas ruminantium: Immobilization, stabilization, and application for xylooligosaccharide hydrolysis. Biocatal. Biotransform. 2016, 34, 161-171. [CrossRef]

292. Trobo-Maseda, L.; Orrego, A.H.; Moreno-Perez, S.; Fernandez-Lorente, G.; Guisan, J.M.; Rocha-Martin, J. Stabilization of multimeric sucrose synthase from Acidithiobacillus caldus via immobilization and post-immobilization techniques for synthesis of UDP-glucose. Appl. Microbiol. Biotechnol. 2018, 102, 773-787. [CrossRef]

293. Rajdeo, K.; Harini, T.; Lavanya, K.; Fadnavis, N.W. Immobilization of pectinase on reusable polymer support for clarification of apple juice. Food Bioprod. Process. 2016, 99, 12-19. [CrossRef]

294. Fresco-Taboada, A.; Serra, I.; Fernandez-Lucas, J.; Acebal, C.; Arroyo, M.; Terreni, M.; de la Mata, I. Nucleoside 2'-deoxyribosyltransferase from psychrophilic bacterium Bacillus psychrosaccharolyticus-Preparation of an immobilized biocatalyst for the enzymatic synthesis of therapeutic nucleosides. Molecules 2014, 19, 11231-11249. [CrossRef] [PubMed]

295. Rocchietti, S.; Ubiali, D.; Terreni, M.; Albertini, A.M.; Fernandez-Lafuente, R.; Guisan, J.M.; Pregnolato, M. Immobilization and stabilization of recombinant multimeric uridine and purine nucleoside phosphorylases from Bacillus subtilis. Biomacromolecules 2004, 5, 2195-2200. [CrossRef] [PubMed]

296. Ubiali, D.; Rocchietti, S.; Scaramozzino, F.; Terreni, M.; Albertini, A.M.; Fernandez-Lafuente, R.; Guisan, J.M.; Pregnolato, M. Synthesis of 2'-deoxynucleosides by transglycosylation with new immobilized and stabilized uridine phosphorylase and purine nucleoside phosphorylase. Adv. Synth. Catal. 2004, 346, 1361-1366. [CrossRef]

297. Ricca, E.; Brucher, B.; Schrittwieser, J.H. Multi-enzymatic cascade reactions: Overview and perspectives. Adv. Synth. Catal. 2011, 353, 2239-2262. [CrossRef]

298. Zhang, G.; Quin, M.B.; Schmidt-Dannert, C. Self-Assembling Protein Scaffold System for Easy in Vitro Coimmobilization of Biocatalytic Cascade Enzymes. ACS Catal. 2018, 8, 5611-5620. [CrossRef]

299. Walsh, C.T.; Moore, B.S. Enzymatic cascade reactions in biosynthesis. Angew. Chem. Int. Ed. 2019, 58, 6846-6879. [CrossRef] [PubMed]

300. Kuzmak, A.; Carmali, S.; von Lieres, E.; Russell, A.J.; Kondrat, S. Can enzyme proximity accelerate cascade reactions? Sci. Rep. 2019, 9, 455. [CrossRef] [PubMed]

301. Arana-Peña, S.; Mendez-Sanchez, C.; Rios, N.S.; Ortiz, C.; Gonçalves, L.R.B.; Fernandez-Lafuente, R. New applications of glyoxyl-octyl agarose in lipases co-immobilization: Strategies to reuse the most stable lipase. Int. J. Biol. Macromol. 2019, 131, 989-997. [CrossRef]

302. Rios, N.S.; Arana-Peña, S.; Mendez-Sanchez, C.; Ortiz, C.; Gonçalves, L.R.B.; Fernandez-Lafuente, R. Reuse of lipase from Pseudomonas fluorescens via its step-by-step coimmobilization on glyoxyl-octyl agarose beads with least stable lipases. Catalysts 2019, 9, 487. [CrossRef]

303. Zaak, H.; Kornecki, J.F.; Siar, E.H.; Fernandez-Lopez, L.; Corberán, V.C.; Sassi, M.; Fernandez-Lafuente, R. Coimmobilization of enzymes in bilayers using PEI as a glue to reuse the most stable enzyme: Preventing PEI release during inactivated enzyme desorption. Process Biochem. 2017, 61, 95-101. [CrossRef]

304. Peirce, S.; Virgen-Ortíz, J.J.; Tacias-Pascacio, V.G.; Rueda, N.; Bartolome-Cabrero, R.; Fernandez-Lopez, L.; Russo, M.E.; Marzocchella, A.; Fernandez-Lafuente, R. Development of simple protocols to solve the problems of enzyme coimmobilization. Application to coimmobilize a lipase and a $\beta$-galactosidase. RSC Adv. 2016, 6, 61707-61715. [CrossRef]

305. Pereira-Rodriguez, A.; Fernandez-Leiro, R.; Gonzalez-Siso, M.I.; Cerdan, M.E.; Becerra, M.; Sanz-Aparicio, J. Structural basis of specificity in tetrameric Kluyveromyces lactis beta-galactosidase. J. Struct. Biol. 2012, 177, 392-401. [CrossRef] [PubMed]

306. Kim, C.S.; Ji, E.S.; Oh, D.K. Expression and characterization of Kluyveromyces lactis beta-galactosidase in Escherichia coli. Biotechnol. Lett. 2003, 25, 1769-1774. [CrossRef] [PubMed]

307. Henriques, R.O.; Bork, J.A.; Fernandez-Lorente, G.; Guisan, J.M.; Furigo, A.; de Oliveira, D.; Pessela, B.C. Co-immobilization of lipases and beta-D-galactosidase onto magnetic nanoparticle supports: Biochemical characterization. Mol. Catal. 2018, 453, 12-21. [CrossRef] 
308. Santos, J.C.S.D.; Barbosa, O.; Ortiz, C.; Berenguer-Murcia, A.; Rodrigues, R.C.; Fernandez-Lafuente, R. Importance of the support properties for immobilization or purification of enzymes. ChemCatChem 2015, 7, 2413-2432. [CrossRef]

309. Virgen-Ortíz, J.J.; Peirce, S.; Tacias-Pascacio, V.G.; Cortes-Corberan, V.; Marzocchella, A.; Russo, M.E.; Fernandez-Lafuente, R. Reuse of anion exchangers as supports for enzyme immobilization: Reinforcement of the enzyme-support multiinteraction after enzyme inactivation. Process Biochem. 2016, 51, 1391-1396. [CrossRef]

310. Virgen-Ortíz, J.J.; Pedrero, S.G.; Fernandez-Lopez, L.; Lopez-Carrobles, N.; Gorines, B.C.; Otero, C.; Fernandez-Lafuente, R. Desorption of lipases immobilized on octyl-agarose beads and coated with ionic polymers after thermal inactivation. Stronger adsorption of polymers/unfolded protein composites. Molecules 2017, 22, 91. [CrossRef]

311. Virgen-Ortíz, J.J.; Tacias-Pascacio, V.G.; Hirata, D.B.; Torrestiana-Sanchez, B.; Rosales-Quintero, A.; Fernandez-Lafuente, R. Relevance of substrates and products on the desorption of lipases physically adsorbed on hydrophobic supports. Enzym. Microb. Technol. 2017, 96, 30-35. [CrossRef]

312. Hirata, D.B.; Albuquerque, T.L.; Rueda, N.; Virgen-Ortiz, J.J.; Tacias-Pascacio, V.G.; Fernandez-Lafuente, R. Evaluation of different immobilized lipases in transesterification reactions using tributyrin: Advantages of the heterofunctional octyl agarose beads. J. Mol. Catal. B Enzym. 2016, 133, 117-123. [CrossRef]

313. Hirata, D.B.; Albuquerque, T.L.; Rueda, N.; Sanchez-Montero, J.M.; Garcia-Verdugo, E.; Porcar, R.; Fernandez-Lafuente, R. Advantages of heterofunctional octyl supports: Production of 1,2-dibutyrin by specific and selective hydrolysis of tributyrin catalyzed by immobilized lipases. ChemistrySelect 2016, 1, 3259-3270. [CrossRef]

314. Rios, N.S.; Mendez-Sanchez, C.; Arana-Peña, S.; Rueda, N.; Ortiz, C.; Gonçalves, L.R.B.; Fernandez-Lafuente, R. Immobilization of lipase from Pseudomonas fluorescens on glyoxyl-octyl-agarose beads: Improved stability and reusability. Biochim. Biophys. Acta Proteins Proteom. 2019, in press. [CrossRef] [PubMed]

315. Rueda, N.; dos Santos, J.C.S.; Torres, R.; Ortiz, C.; Barbosa, O.; Fernandez-Lafuente, R. Improved performance of lipases immobilized on heterofunctional octyl-glyoxyl agarose beads. RSC Adv. 2015, 5, 11212-11222. [CrossRef]

316. Fernandez-Lopez, L.; Virgen-Ortiz, J.J.; Pedrero, S.G.; Lopez-Carrobles, N.; Gorines, B.C.; Otero, C.; Fernandez-Lafuente, R. Optimization of the coating of octyl-CALB with ionic polymers to improve stability and decrease enzyme leakage. Biocatal. Biotransform. 2018, 36, 47-56. [CrossRef]

317. Zaak, H.; Fernandez-Lopez, L.; Otero, C.; Sassi, M.; Fernandez-Lafuente, R. Improved stability of immobilized lipases via modification with polyethylenimine and glutaraldehyde. Enzym. Microb. Technol. 2017, 106, 67-74. [CrossRef]

318. Fernandez-Lopez, L.; Pedrero, S.G.; Lopez-Carrobles, N.; Virgen-Ortiz, J.J.; Gorines, B.C.; Otero, C.; Fernandez-Lafuente, R. Physical crosslinking of lipase from Rhizomucor miehei immobilized on octyl agarose via coating with ionic polymers avoiding enzyme release from the support. Process Biochem. 2017, 54, 81-88. [CrossRef]

319. Fernandez-Lorente, G.; Filice, M.; Lopez-Vela, D.; Pizarro, C.; Wilson, L.; Betancor, L.; Avila, Y.; Guisan, J.M. Cross-linking of lipases adsorbed on hydrophobic supports: Highly selective hydrolysis of fish oil catalyzed by RML. J. Am. Oil Chem. Soc. 2011, 88, 801-807. [CrossRef]

320. Pizarro, C.; Branes, M.C.; Markovits, A.; Fernandez-Lorente, G.; Guisan, J.M.; Chamy, R.; Wilson, L. Influence of different immobilization techniques for Candida cylindracea lipase on its stability and fish oil hydrolysis. J. Mol. Catal. B Enzym. 2012, 78, 111-118. [CrossRef]

321. Fuentes, M.; Segura, R.L.; Abian, O.; Betancor, L.; Hidalgo, A.; Mateo, C.; Fernandez-Lafuente, R.; Guisan, J.M. Determination of protein-protein interactions through aldehyde-dextran intermolecular cross-linking. Proteomics 2004, 4, 2602-2607. [CrossRef]

322. Pessela, B.C.C.; Munilla, R.; Betancor, L.; Fuentes, M.; Carrascosa, A.V.; Vian, A.; Fernandez-Lafuente, R.; Guisan, J.M. Ion exchange using poorly activated supports, an easy way for purification of large proteins. J. Chromatogr. A 2004, 1034, 155-159. [CrossRef]

323. Fuentes, M.; Mateo, C.; Pessela, B.C.C.; Guisan, J.M.; Fernandez-Lafuente, R. Purification, stabilization, and concentration of very weak protein-protein complexes: Shifting the association equilibrium via complex selective adsorption on lowly activated supports. Proteomics 2005, 5, 4062-4069. [CrossRef] 
324. Kvasnov, B.A.; Shalaev, P.V.; Dolgushin, S.A. Study of the aggregation of bovine serum albumin monomers in aqueous dispersions with different acid-base value $\mathrm{pH}$. In Proceedings of the 2018 IEEE Conference of Russian Young Researchers in Electrical and Electronic Engineering (ElConRus), Moscow, Russia, 29 January-1 February 2018; pp. 1907-1909.

325. Polyanichko, A.M.; Mikhailov, N.V.; Romanov, N.M.; Baranova, Y.G.; Chikhirzhina, E.V. Intermolecular Interactions in Solutions of Serum Albumin. Cell Tissue Biol. 2017, 11, 9-15. [CrossRef]

326. Militello, V.; Casarino, C.; Emanuele, A.; Giostra, A.; Pullara, F.; Leone, M. Aggregation kinetics of bovine serum albumin studied by FTIR spectroscopy and light scattering. Biophys. Chem. 2004, 107, 175-187. [CrossRef] [PubMed]

327. Militello, V.; Vetri, V.; Leone, M. Conformational changes involved in thermal aggregation processes of bovine serum albumin. Biophys. Chem. 2003, 105, 133-141. [CrossRef]

328. Fuentes, M.; Pessela, B.C.C.; Mateo, C.; Palomo, J.M.; Batalla, P.; Fernandez-Lafuente, R.; Guisan, J.M. Adsorption behavior of bovine serum albumin on lowly activated anionic exchangers suggests a new strategy for solid-phase proteomics. Biomacromolecules 2006, 7, 1357-1361. [CrossRef] [PubMed]

(C) 2019 by the authors. Licensee MDPI, Basel, Switzerland. This article is an open access article distributed under the terms and conditions of the Creative Commons Attribution (CC BY) license (http://creativecommons.org/licenses/by/4.0/). 